\title{
Relações étnico-raciais, de gênero e sexualidade
} perspectivas contemporâneas

\author{
Aparecida de Jesus Ferreira (org.)
}

FERREIRA, AJ., org. Relações étnico-raciais, de gênero e sexualidade: perspectivas contemporâneas [online]. Ponta Grossa: Editora UEPG, 2014, 182 p. ISBN 978-85-7798-210-3. Available from SciELO Books $<\underline{\text { http://books. scielo.org }>\text {. }}$

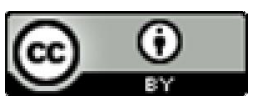

All the contents of this work, except where otherwise noted, is licensed under a Creative Commons Attribution 4.0 International license.

Todo o conteúdo deste trabalho, exceto quando houver ressalva, é publicado sob a licença Creative Commons Atribição 4.0.

Todo el contenido de esta obra, excepto donde se indique lo contrario, está bajo licencia de la licencia Creative Commons Reconocimento 4.0. 


\section{RELACÕES ÉTNICO-RACIAIS, DE GÊNERO E SEXUALIDADE PERSPECTIVAS CONTEMPORÂNEAS}


UNIVERSIDADE ESTADUAL DE PONTA GROSSA

\begin{tabular}{|c|c|}
\hline REITOR & EDITORA UEPG \\
\hline Carlos Luciano Sant'Ana Vargas & Lucia Cortes da Costa \\
\hline PRÓ-REITOR DE EXTENSÃO & CONSELHO EDITORIAL \\
\hline E ASSUNTOS CULTURAIS & Lucia Cortes da Costa (Presidente) \\
\hline \multirow[t]{6}{*}{ Gisele Alves de Sá Quimelli } & David de Souza Jaccoud Filho \\
\hline & Fábio André dos Santos \\
\hline & Gisele Alves de Sá Quimelli \\
\hline & José Augusto Leandro \\
\hline & Osvaldo Mitsuyuki Cintho \\
\hline & Silvio Luiz Rutz da Silva \\
\hline
\end{tabular}




\section{Aparecida de Jesus Ferreira}

Organizadora

\section{RELAĢ̃̃es ÉTMICO-RAGIAIS, DE GênERO E SEXUALIDADE PERSPECTIUAS GONTEMPORÂNEAS}

Editora

UEPG 
Copyright (C) by Aparecida de Jesus Ferreira \& Editora UEPG

Nenhuma parte deste livro, sem autorização prévia por escrito da Editora, poderá ser reproduzida ou transmitida, sejam quais forem os meios empregados: eletrônicos, mecânicos, fotográficos, gravação ou quaisquer outros.

\title{
Equipe Editorial
}

\author{
COORDENAÇÃo EDITORIAL Lucia Cortes da Costa \\ PREPARAÇÃo dE ORIGINAIS E FICHA CATALOGRÁFICA Cristina Maria Botelho \\ REVISÃo Otávio Corazzim/Tikinet \\ PROJETO GRÁfico, CAPA E DiagramaÇão Aline Maya/Tikinet
}

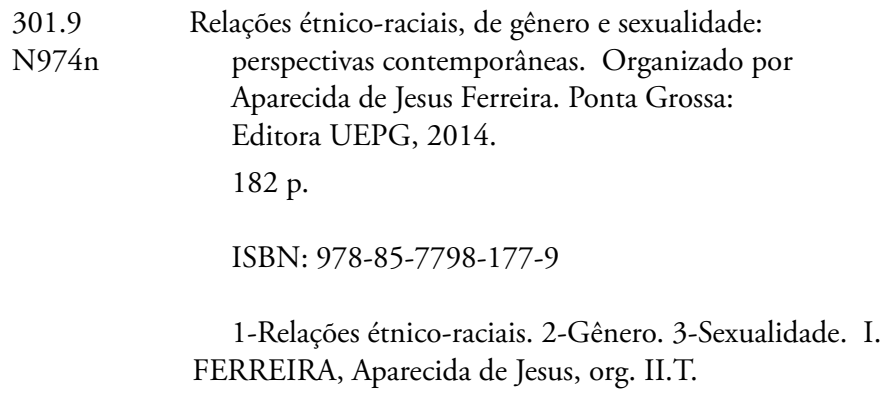

301.9 Relaçóes étnico-raciais, de gênero e sexualidade:

N974n perspectivas contemporâneas. Organizado por Aparecida de Jesus Ferreira. Ponta Grossa:

Editora UEPG, 2014.

$182 \mathrm{p}$.

ISBN: 978-85-7798-177-9

1-Relaçôes étnico-raciais. 2-Gênero. 3-Sexualidade. I. FERREIRA, Aparecida de Jesus, org. II.T.

Depósito legal na Biblioteca Nacional

Editora filiada à $\mathrm{ABEU}$

Associação Brasileira das Editoras Universitárias

\section{Editora UEPG}

Praça Santos Andrade, n. 1

84030-900 - Ponta Grossa - Paraná

Fone: (42) 3220-3306

E-mail: editora@uepg.br 


\section{AGRADECIMENTOS}

Meus agradecimentos são a todos aqueles e aquelas que, de alguma forma, direta ou indiretamente, colaboraram para que este livro fosse possível. Em especial, agradeço:

» à Editora da UEPG, mais especificamente à ex editora Beatriz Nadal por apoiar a proposta; e também à editora atual Lucia Cortes da Costa pelo suporte e finalizaçáo do processo de publicação.

» à professora Anete Abramowicz, que contribuiu com o texto do Prefácio;

» aos participantes do NUREGS da UEPG, Édina Schimanski, Ione Jovino da Silva, Marly Catarina Soares, Pascoalina Bailon de Oliveira Saleh e aos demais parceiros e parceiras de outras universidades: Alexandre Soares Ferrari, André Luiz Sena Mariano, Jamil Cabral Sierra, Paulo Vinicius Baptista da Silva e Tereza Lopes Miranda, que colaboraram para a criação deste livro;

» ao ex pró-reitor de extensão da UEPG Miguel Sanches Neto pelo apoio inicial dado na criação do NUREGS;

» à pró-reitora de extensão Gisele Alves de Sá Quimelli pelo apoio dado para que vários dos eventos organizados pelo NUREGS pudessem acontecer;

» aos palestrantes dos eventos organizados pelo NUREGS Luiz Fernando Cerri (UEPG), Sonia Maria Marques (UNIOESTE) e Paulo Vinicius Baptista da Silva (UFPR);

» à APP-Sindicato, ao Núcleo Regional de Educação de Ponta Grossa e à Prefeitura de Ponta Grossa pela parceria feita com o NUREGS com o intuito de enviar os/as professores/as para os cursos de formação continuada, seminários e palestras; 
» aos pareceristas pelas leituras cuidadosas e sugestôes feitas;

» aos bolsistas Fábio Kobinski e Fernanda Brigolla, que colaboraram nos eventos organizados pelo NUREGS;

» aos integrantes do NUREGS que colaboraram com todos os eventos organizados pelo NUREGS ministrando palestras e minicursos: Cloris Porto Torquato, Édina Schimanski, Ione da Silva Jovino, José Roberto de Vasconcelos Galdino, Marly Catarina Soares e Pascoalina Bailon de Oliveira Saleh.

» à Fundação Araucária.

Aparecida de Jesus Ferreira

Organizadora

Professora Associada da UEPG

Pesquisadora do NUREGS 


\section{SUMÁRIO}

PREFÁCIO

Anete Abramowicz

INTRODUÇÁO

Aparecida de Jesus Ferreira

PARTE 1. RELAÇÓES RACIAIS

Literatura oral afro-brasileira e alteridade

Paulo Vinicius Baptista da Silva

Crianças negras nas imagens, imagens de crianças negras:

infância e raça na iconografia do século XIX

Ione da Silva Jovino

PARTE 2. RELAÇÓES DE GÊNERO

Relaçóes de gênero: algumas consideraçóes conceituais

Tereza Lopes Miranda \& Edina Schimanski

"Mais cedo ou mais tarde sua mulher irá dirigir": identidades de gênero em anúncios de carro

Pascoalina Bailon de Oliveira Saleh

A (des)construçáo da identidade feminina em $A$ bora $d a$ estrela 
Discurso do sujeito: a homossexualidade em textos jornalísticos contemporâneos

Alexandre Sebastiāo Ferrari Soares

Campanhas de prevenção contra HIV/AIDS entre homossexuais e a governamentalidade dos corpos e das práticas sexuais no discurso midiático

Jamil Cabral Sierra

A presença da diversidade cultural nas pesquisas sobre formação docente 153

André Luiz Sena Mariano 


\section{PREFÁCIO}

Há uma nova paisagem científica na educação brasileira. Temas antes considerados secundários, periféricos e/ou subalternos começam a ganhar centralidade a partir da década de 1980. O elemento desencadeante desta nova perspectiva é a constatação de que, nos últimos vinte anos, observamos a crescente utilizaçáo da categoria diversidade e diferença e de temas a ela relacionados no debate internacional e brasileiro. A ideia de diversidade tornou-se, frente à crescente afirmação das identidades, um fenômeno significativo especialmente em sociedades oriundas do colonialismo europeu, onde grupos e indivíduos reafirmam seus particularismos locais, suas identidades étnicas, raciais, culturais ou religiosas, chamando a atenção de organismos internacionais a atributos da globalização que não são apenas econômicos ou tecnológicos, mostrando a inadequação das análises estritamente socioeconômicas.

É no interior desta nova paisagem científica que a obra Relaçôes étnico-raciais, de gênero e sexualidade: perspectivas contemporâneas surge e vem a contribuir para o entendimento daquilo que não é apenas científico, mas também político, e daqueles que lutam pela afirmaçáo das diferenças. O livro não se apoia na ideia de uma indiferença em relação à diversidade, nem mesmo que seja indiferente aos territórios, às origens, à cultura das pessoas e dos coletivos sociais, ele se apoia no princípio de diferença que está na raiz da nova proposta de escola e de sociedade que a obra incita a construir.

Temas antes negligenciados que estáo na clave da diferença, como as relações de gênero, de sexualidade, étnico-raciais ou etárias, ascendem, dão uma visibilidade inaudita à realidade das relações sociais no Brasil e fazem parte daquilo que hoje é considerado tema premente da contemporaneidade. Cultura, gênero, sexualidade e raça são temáticas contemporâneas, e isto significa dizer que são de certa complexidade teórica e prática, pois fazem parte do presente e da vida cotidiana de cada um. Na medida em que tais temáticas são contemporâneas, elas trazem as luzes e as sombras de uma época. Isto significa dizer que esses temas trazem concomitantemente a luz de nossa época e a sombra íntima que acompanha tais temáticas, e 
que no ambiente escolar, por exemplo, tem colocado crianças e jovens brasileiros que portam alguma diferença no lugar do desvio.

A abertura política ocorrida no país a partir das duas últimas décadas do século XX trouxe um conjunto de manifestaçóes de segmentos sociais que não se sentiam contemplados nas políticas públicas em diversas esferas da vida social. Uma das evidências desse descontentamento foi a emergência de inúmeros movimentos reivindicatórios, dos quais destacam-se o movimento feminista, o movimento LGBT e o movimento negro. Negros, mulheres, gays, lésbicas, etc. passaram a expressar reivindicaçôes para coibir o tratamento discriminatório que recebem em seu cotidiano de relações. Essas manifestaçóes contribuíram para dar visibilidade aos processos de discriminação que ocorrem em vários âmbitos.

É no rastro desse campo de batalha que tal livro procura se inscrever. Não basta dizer: "sejam tolerantes e respeitem a dimensão da diversidade de nosso país”, uma frase tão em voga em tempos neoliberais. É preciso ir além, pois não há nada a tolerar na medida em que não há hierarquia nas diferenças, não há uma norma ou normal, pois é preciso produzir a diferença o tempo todo. É nesse sentido que o livro pode contribuir neste movimento afirmativo das diferenças. 


\section{INTRODUÇÃO}

Este livro tem como principal interesse apresentar o NUREGS Núcleo de Relaçóes Étnico-Raciais, de Gênero e Sexualidade para a comunidade acadêmica, pesquisadores, demais Núcleos que tratam de temas relacionados e interessados no tema, bem como divulgar pesquisas e reflexóes sobre raça, gênero e sexualidade.

Os capítulos apresentados a seguir são de pesquisadores que fazem parte do NUREGS, de convidados e de quem colaborou com as atividades que o NUREGS vem promovendo desde 2010. Os pesquisadores que colaboraram com essa coletânea também estão envolvidos em programas de pós-graduação em diversas universidades no Brasil.

O livro se divide em três partes. A primeira traz resultados de pesquisas e reflexôes sobre relações raciais e inicia com a proposta do capítulo escrito por Paulo Vinicius Baptista da Silva que discute as relaçóes entre a literatura oral afro-brasileira e a educação. $\mathrm{O}$ capítulo propóe que valorizar as origens afro-brasileiras é importante para ressignificar o que é ser negro no Brasil e o que é significativo para os alunos negros, como via de identificação positiva de suas origens e construção da alteridade. As formas de narrativa da literatura oral afro-brasileira podem ser ponto de partida para a estruturação da alteridade. A análise dos aspectos formais e narrativas se relaciona com a "alfabetização da diáspora", isto é, com o desenvolvimento de habilidades para a leitura de signos culturais relacionados à vida das crianças negras, sendo que os aspectos estéticos e lúdicos das histórias são elementos para afirmação da diversidade. O capítulo demonstra que a análise das histórias também foca na possibilidade dada aos alunos de elaborar uma noção de "branquidade" e estabelecer uma cidadania cultural que afirme a diferença e não categorize o outro como objeto de avaliação.

O capítulo escrito por Ione da Silva Jovino apresenta resultados de uma pesquisa formulada com base na necessidade de visibilizar a presença da criança negra no século XIX, buscando configurar a infância a partir desse recorte. A autora mostra de que maneira as crianças negras são vistas utilizando imagens produzidas no século XIX, tendo como ponto de 
partida as reflexóes feitas a partir da análise de gravuras de Jean-Baptiste Debret e retratos de Militáo Augusto de Azevedo. Ione busca estabelecer uma "discussão" com a história das crianças e da infância no Brasil, destacando a importância da imagem para a compreensão da construção histórica da infância dos negros brasileiros. Partindo de uma proposta de análise, pela qual náo se buscou o que as imagens escondiam, mas o que revelavam das modalidades e possibilidades de existência da infância negra no século XIX, observou-se a literatura sobre escravidáo para buscar nela a infância escrava que aparecia nas famosas pranchas de Debret. A autora também encontra outras imagens que mostram outros aspectos da infância negra, o que resultou na verificação dos retratos produzidos por Militão, que mostram crianças negras bem diferentes das retratadas nas primeiras imagens, pertencentes a famílias ou comunidades que recorreram ao recurso tecnológico da fotografia para guardar suas memórias por meio da perpetuação das imagens das crianças. As conclusôes a que Ione chega dão visibilidade ao sentimento da infância negra, evidenciado pelos modos específicos de cuidar das crianças, preservados e recriados pelos negros no contexto escravista brasileiro.

A segunda parte do livro traz pesquisas e reflexôes sobre as relaçôes de gênero. O capítulo escrito por Édina Schimanski e Tereza Lopes Miranda tem como objeto de estudo as questóes relacionadas ao gênero e suas contradiçóes no contexto social a partir das relaçóes estabelecidas entre homens e mulheres na sociedade. O texto é centrado na conceituação de gênero, buscando uma interlocução direta com o debate atual acerca do tema, portanto as autoras compreendem que falar sobre gênero implica $a$ priori discorrer sobre identidade de gênero, a qual diz respeito à percepçáo subjetiva de ser masculino ou feminino, conforme os atributos, o comportamento e os papéis convencionalmente estabelecidos para homens e mulheres no contexto social.

Pascoalina Bailon de Oliveira Saleh analisa anúncios de carros veiculados na mídia impressa e televisiva, enfocando os mecanismos linguísticos, discursivos e textuais neles mobilizados a fim de explicitar o papel da linguagem nas configuraçóes de identidade de gênero nessas propagandas. A linguagem é tomada na sua condição de prática social, a partir da qual as relaçôes sociais se definem e, portanto, os sentidos e os sujeitos são constituídos. Dessa forma, Pascoalina percebe que o sentido não está na materialidade do texto em si, mas na relação que este mantém com quem 
o produz, com quem o lê ou escuta, com outros textos e com outros discursos possíveis. Isso significa tomar não só as circunstâncias de enunciação imediatas, mas também o contexto social, histórico e ideológico como constitutivos da linguagem e do próprio sujeito, entendendo-se a ideologia não como ocultação dos sentidos, mas como mecanismo que produz a naturalização dos sentidos (ORLANDI, 1996). Nessa perspectiva o anúncio publicitário é entendido como uma prática discursiva cujo objetivo é ofertar o produto, ou seja, apresentá-lo para que seja adquirido, conforme a ótica de mercado (CAROZZA, 2010). Com base na análise, a autora conclui que, embora os anúncios de carro projetem tanto uma identidade masculina quanto feminina, eles são predominantemente dirigidos aos homens, cabendo à mulher a posição de "carona", tanto no momento de utilizá-lo quanto no momento de escolhê-lo.

O capítulo escrito por Marly Catarina Soares aborda as personagens femininas do romance A Hora da Estrela, de Clarice Lispector: Macabéa, as quatro Marias, Dona Carlota, a Tia e Glória. Todas apresentam características de quem vive em situaçáo de marginalidade tanto no aspecto econômico, como no social e profissional. São mulheres que não estudaram, não têm profissão qualificada e não se casaram. Macabéa é uma datilógrafa medíocre, as Marias trabalham como balconistas, Glória é secretária, mas se utiliza de seus atributos físicos para atingir seus objetivos, e Dona Carlota é uma ex-prostituta que ganha a vida como cartomante. Todas procuram sobreviver num mundo hostil e não há qualquer indício de que o destino dessas mulheres possa mudar, tirando-as da mediocridade em que vivem. No filme de Suzana do Amaral, a situação das personagens femininas segue a mesma trajetória de mediocridade apresentada no romance. A autora promove uma discussão sobre a (des)construção da identidade feminina no romance e no filme de mesmo título.

$\mathrm{Na}$ terceira parte do livro, o artigo escrito por Alexandre Sebastiáo Ferrari Soares analisa as matérias jornalísticas da segunda metade das décadas de 1980 e 2000, mais especificamente entre os anos de 1985-1990 e 2005-2010, veiculados por meios de comunicação de circulação nacional, para, entre outros objetivos, compreender como os sujeitos homossexuais foram ou são construídos nestes meios de comunicação e para compreender os efeitos de sentido que são produzidos sobre esses sujeitos. Além disso, já que o autor analisa dois corpora distintos, produzidos com um intervalo de aproximadamente vinte anos, o autor pode perceber quais 
deslocamentos de sentido foram realizados sobre esses sujeitos. Para tanto ele usa como orientação teórica a análise de discurso francesa, cuja perspectiva é de que o sujeito e o sentido se constituem ao mesmo tempo, isto é, o sujeito se significa ao dar sentido.

Jamil Cabral Sierra apresenta em seu capítulo uma campanha publicitária de prevenção contra HIV/Aids entre homossexuais e tenta mostrar, a partir de Foucault, como os enunciados de prevenção do corpo articulam, na contemporaneidade, representaçóes da homossexualidade que continuam sustentando o pavor ao que é considerado diferente e negando a multiplicidade sexual se ela estiver escapando à norma do padrão de consumo e da consciência burguesa. Desse modo, Jamil demonstra que esses enunciados de prevenção do corpo reforçam os processos normalizadores de nossa época, ajustando os corpos e as práticas sexuais/afetivo-amorosas às reconfiguraçóes biopolíticas de gerenciamento da vida e de controle da subjetividade dos sujeitos.

O capítulo escrito por André Luiz Sena Mariano procura discutir, por meio de um levantamento bibliográfico, a inserção do multiculturalismo na pesquisa sobre formação de professores. O autor estabeleceu um recorte temporal entre os anos de 2000 e 2006 e elegeu como fonte de coleta de dados os trabalhos apresentados na ANPEd e no ENDIPE e artigos publicados em periódicos com foco na discussão do multiculturalismo. É possível apontar que há uma polissemia entre os estudos selecionados, como, por exemplo, nas perspectivas multicultural crítica, intercultural e pós-colonial. $\mathrm{O}$ autor constatou que os resultados dos textos selecionados revelam um tratamento mais próximo de uma acepção conservadora e encerra ressaltando a importância do multiculturalismo crítico, sobretudo do conceito de identidade de fronteira, bem como deve ser dado maior destaque às questóes culturais na formação de professores, ao invés de restringir a preocupação às discussóes alusivas às múltiplas acepçóes de multiculturalismo.

Os temas deste livro certamente possibilitam olhar para a escola e a sociedade tentando refletir e perceber possibilidades de entender o contexto em que estamos inseridos, atuando com um olhar questionador e propondo novas atuaçóes para as questóes de raça, gênero e sexualidade. 


\section{PARTE 1}

\section{RELAÇÕES RACIAIS}




\title{
LITERATURA ORAL \\ AFRO-BRASILEIRA E ALTERIDADE
}

\author{
Paulo Vinicius Baptista da Silva \\ Universidade Federal do Paraná
}

Por que contar histórias afro-brasileiras? A proposta deste artigo é discutir as possibilidades de uso das fábulas afro-brasileiras como forma de valorização do ethos africano, como afirmação de identidade e valorização da herança da Mãe África e como fonte de informaçáo sobre o continente de nossa origem, população afro-brasileira.

O Racismo à brasileira (GUIMARÁES, 2002; TELLES, 2003) divulga ideias que valorizam em excesso a influência europeia enquanto valores de culturas africanas e indígenas são depreciados e negados e como as políticas de branqueamento foram atuantes em relação a qualquer traço cultural vindo da África. No início do século XX, houve manifestações diversas de religião, música e dança que foram reprimidas e perseguidas. $\mathrm{O}$ branqueamento $^{1}$ divulgou noçóes negativas sobre qualquer valor estético, moral e religioso vindo da África. A cultura portuguesa, e como extensão a europeia, foram compreendidas como base para a "civilização brasileira", numa óptica assimilacionista ${ }^{2}$. O ideário em voga foi, e ainda é, a assimilação

1. Para uma discussão sobre o conceito e sua importância no pensamento racial brasileiro, ver Skidmore, 1976.

2. A "civilizaçấo brasileira" foi descrita como um rio cujo leito é a cultura lusitana, que recebe os afluentes indígena e africano (von Martius, citado por Scwarcz, 2000). Sobre a perspectiva assimilacionista em textos seminais para a compreensão do Brasil, de Gilberto Freire, Sérgio Buarque de Holanda e Caio Prado Júnior, ver Norvell, 2002. A identidade brasileira é forjada neste mito, na fábula do "cadinho das raças". Sobre o conceito de mito fundador, ver Guimarães, 2002. 
de "negros e mestiços" na sociedade brasileira. Conhecemos os elementos de influência indígena ou africana, na alimentação e no vocabulário. E só. Os indígenas e os negros são tratados na maioria das vezes como objeto e raramente como sujeitos na construção deste país chamado Brasil, sendo que ancestralidade africana e indígena ainda é repudiada.

Curiosamente, foi durante o governo militar que um movimento de valorização da herança africana ganhou corpo. Na década de 1970, este movimento ganhou força inicial principalmente em Salvador e no Rio de Janeiro, onde o patrocínio à cultura afro-brasileira, "uma espécie de renascimento cultural” (GUIMARÁES, 2002, p. 158) ocorreu. Alguns marcos importantes são: a Semana Afro-brasileira de 1974, com exposição de arte e cultura negras; a criação, no mesmo ano, do Instituto de Pesquisa das Culturas Negras (IPCN); a fundação da Sociedade de Intercâmbio Brasil-África (SINBA) no Rio de Janeiro; a Confederação Baiana dos Cultos Afro-Brasileiros e o bloco afro Ilê-Ayê, em Salvador; e em 1976 um decreto do governo estadual que colocou fim na necessidade de licença policial para o funcionamento de terreiros de candomblé.

Tais movimentos buscam restabelecer o direito à alteridade, à formação da identidade fundamentada nos valores e contribuiçóes da ancestralidade africana. É nesse sentido que abordamos o contar de histórias africanas ou afro-brasileiras, com o propósito de construir um país multirracial, onde a singularidade e a afirmação da diversidade cultural sejam direitos legítimos, à frente de um multiculturalismo retórico e fácil.

Contar histórias é universal, tanto como entretenimento quanto forma de divulgação de cultura. A África não é diferente dos outros continentes nesse sentido, porém as diversas naçóes fazem uso da literatura oral de formas variadas e, neste artigo, estaremos mais focados em pontos comuns do que na diversidade. Apontamos elementos da cosmovisão africana presentes em diversas naçóes que nos ajudam no "alfabetismo da diáspora”, isto é, auxiliam a compreensão de nossas raízes africanas.

Podemos começar relatando um fato importante acerca da diversidade africana: a multiplicidade de seu continente: a imensidáo do deserto do Saara divide a África em dois blocos, ao norte temos a África mediterrânea ou árabe, e ao sul a subsaariana ou negra. Náo percamos de vista que é um continente gigantesco, com variaçóes enormes entre as línguas, a economia, a organização social, a alimentação, etc. 
Os narradores de história têm um papel muito importante na maior parte das diversas nações da África negra. A transmissão oral da cultura é feita com grande participação das narraçóes verbais. A voz que evoca os antepassados, as origens e as glórias dos povos transmite, de geração em geraçáo, o conhecimento acumulado pelo povo africano. Em diversos grupos os narradores adquiriram status definido, com determinadas regras, direitos e deveres, chamados por arokin, akpalô kpatita, ologbo ou griotes (CASCUDO, 1984, p. 152). Arokin é a designação dada ao narrador de crônicas do passado. Akpalô significa fazedor de palô ou conto, algo que era profissão na África, onde alguns indivíduos andavam de lugar em lugar recitando contos. No Brasil tal instituição africana esteve presente e é relatada, por exemplo, em Meninos do engenho, de José Lins do Rêgo. Na tradição iorubá/nagô, os griôs ocupam um papel de fundamental importância e lugar de destaque na hierarquia, pois são os que conhecem os itans e as histórias dos orixás e do povo iorubá, e são encarregados de transmitir tal sabedoria aos novos.

No Brasil a profissão de contar histórias é reconhecida como herança negra. $\mathrm{O}$ contar histórias de povoado em povoado, tendo como trabalho usar a arte narrativa para o deleite da populaçáo, chegou a ser exercido no Nordeste brasileiro, de forma similar ao que ocorre em territórios Bantu. A "preta velha" ou o "preto velho"3, os contadores de histórias, são reconhecidos em todo o Brasil. Algumas vezes foram utilizados para reforçar estereótipos racistas, de pessoas avessas ao trabalho ou merecedoras de descrédito, mas em outras manteve-se uma valorização similar à dos povos africanos para cá trazidos. Na transmissão da cultura yorubá, a oralidade tem um valor peculiar, portanto iremos organizar nossa argumentação por meio das próprias narrativas. Pedimos licença aos iniciados para reproduzir este $\operatorname{itam}^{4}$ :

3. O conceito de idade é um ponto que a cosmovisão africana, onde o mais velho é digno de maior respeito, tem a ensinar ao Brasil atual, onde os velhos são, via de regra, desvalorizados.

4. Adaptado de Petrovich e Machado (2000, p. 91-94). Todas as histórias transcritas são versôes da literatura oral por nós adaptadas. 


\section{Oxum na criação do mundo}

No princípio do mundo, Olodumaré enviou todos os orixás para organizarem as coisas na terra. Começaram os trabalhos e as reuniões, mas os homens decidiram que as mulheres não podiam participar. Eles deixavam as mulheres em casa, faziam reuniões para combinar as tarefas e executavam as providências indicadas por Olodumaré.

As mulheres não ficaram nada satisfeitas com esta situação e foram pedir ajuda a Oxum. Chegaram à Mãe das Águas Doces, que foi saudada por seus filhos:

Oxum, mãe da clareza

Graça clara

Mãe da clareza

Enfeita filho com bronze

Fabrica fortuna na água

Cria crianças no rio

Brinca com seus braceletes

Colhe e acolhe segredos

Cava e encova cobres na areia

Fêmea força que não se afronta

Fêmea de quem macho foge

$\mathrm{Na}$ água funda que se assenta profunda

$\mathrm{Na}$ fundura da água que corre

Oxum do seio cheio

Ora leiê, me proteja

És o que tenho -

Me receba ${ }^{5}$

Oxum já sabia o que estava acontecendo e não estava nada contente com a desfeita dos homens. Ela sabia que, para que as coisas andassem bem, todos teriam de ser ouvidos e participar na organização das coisas na terra. As mulheres conversaram durante muito tempo para decidir o que fazer, até que Oxum chegou a uma conclusão e disse:

- Vamos mostrar como somos todos responsáveis pela construção do mundo.

5. Oriki transposto na íntegra, conforme tradução do Yorubá de Antônio Risério (1996, p. 151). Provável fusão verbal de ori (cabeça, destino) com ki (saudar), são complexos poemas, "objetos de linguagem que pontuam todos os momentos e movimentos da existência social na Yorubalândia” (RISÉRIO, 1996, p. 41). 
Enquanto nossas palavras não forem escutadas, vamos parar a construção do mundo. Até que os homens venham falar conosco, todas as mulheres deixarão de parir. Os animais e as plantas também não vão parir, nem dar mais frutos, nem florescer.

A decisão foi acolhida por todas as mulheres e as coisas na terra passaram a andar muito mal.

Os homens foram a Olodumaré para contar os problemas e pedir ajuda. Disseram que estavam fazendo tudo o que Olodumaré havia indicado, mas não queriam a participação das mulheres, dizendo que as coisas de homem e de mulher têm que ser separadas.

Olodumaré respondeu com voz forte:

- Vocês já viram alguma coisa plantada crescer sem água doce? Oxum, a rainha das águas doces, é quem comanda a fertilidade. Oxum é senhora da água fresca e da brisa, mãe dos pássaros e dos peixes, orixá do amor, do doce desejo e da beleza. Sem Oxum nada pode frutificar e progredir.

Os homens voltaram para a terra e foram procurar Oxum. Foram direto a sua casa, e ela já os esperava à porta. Eles a saudaram:

- Agó Nilê! (Com licença).

- Omo Nilê ni ka agô (Filho da casa não pede licença).

Ela os convidou para entrar e eles começaram a conversar. Os homens pediam a Oxum para participar na organização do mundo, mas Oxum se fazia de rogada, e os homens precisaram de muitos pedidos para convencê-la. Quando finalmente ela aceitou, as mulheres voltaram a participar das reuniões e ajudar na organização do mundo.

As coisas logo mudaram. Oxum derramou sua água pelos caminhos do mundo e a terra frutificou. A vida voltou a frutificar, mulheres, fêmeas e plantas voltaram a dar à luz, e os trabalhos de organização da terra passaram a dar os resultados planejados por Olodumaré.

Desde então, ao final de cada assembleia, homens e mulheres passaram a comemorar, cantando e dançando, o reencontro e os resultados.

Entrou na perna de um pinto, façam boca de siri, se quiserem saber mais, perguntem ao mestre Didi!

Os orixás, pais míticos de grupos iorubá, são elementos fundamentais da dimensão simbólica da vida social. Nas terras onde viviam os povos 
iorubanos, atualmente divididas em naçôes distintas, ocorreu uma modernização que fez com que os orixás deixassem de ter um papel central na organização da vida (ADÉKÒYÀ, 1999). No Brasil, são cultuados aqueles que eram difundidos em maiores extensóes do território, onde o candomblé representa uma importante forma de resistência cultural e agrega influências de outros grupos. A religião é praticada no país inteiro, tendo influência muito forte no nordeste brasileiro, em especial no estado da Bahia. Os terreiros de candomblé além de funcionar como forma de resistência cultural, também são uma forma de transmissão de diversos aspectos de culturas africanas. A perseguição dos seguidores pela polícia durou quase todo o século XX, o que convergiu para a forma de intolerância religiosa que ocorre do final dos anos 1990 aos dias atuais. Como exemplo do papel das narrativas orais na conservação da cultura e do pensamento iorubano no Brasil, temos a obra de Mestre Didi ${ }^{6}$, que exerce o cargo de sacerdote supremo do culto dos ancestrais Egungun no Ilê Axê Opó Afonjá. Além de publicaçôes diversas de itans como forma de divulgação da cultura do candomblé, uma experiência vivida demonstra o papel de conservação do legado cultural. Nos anos 1960, já reconhecido como artista plástico, Mestre Didi fez uma viagem à Nigéria. Recebido por líderes em audiência, durante o encontro ele entoou o canto de sua família, que imediatamente foi reconhecido pelo anfitriâo e que indicou a Mestre Didi o local de moradia de sua família na Nigéria. Ter informação mínima sobre suas origens africanas é impossível para a maior parte dos brasileiros, mas foi possível a Mestre Didi por força da cultura preservada no terreiro de candomblé.

6. Deoscóredes Maximiliano dos Santos (Salvador - BA, 02/12/1917), conhecido popularmente como Mestre Didi, é escritor, artista plástico, e sacerdote afro-brasileiro. É filho de Maria Bibiana do Espirito Santo (conhecida como Máe Senhora, descendente da tradicional família Asipa, originária de Oyo e Ketu, importantes cidades do império Yoruba) e Arsenio dos Santos. Aos oito anos de idade, Mestre Didi foi iniciado na religião de origem africana, e Mãe Aninha, tratada como avó por Didi, foi quem o iniciou no culto aos Orixás e lhe deu o título de Assogba, Supremo Sacerdote do Culto de Obaluaiyê. Em 1975, recebe o cargo de Alapini, e em 1983, o cargo de Baba Mogbá Oni Xangô, recebido diretamente pela casa de Xangô, em Benin, e entregue pelo rei de Ketu. Em 1980, fundou a Sociedade Cultural e Religiosa Ilê Asipá do culto aos ancestrais Egun em Salvador, da qual também foi presidente. Como escultor, tem suas obras expostas em importantes museus e casas de arte pelo mundo, como o Museu de Arte Moderna em Salvador e o Museu Picasso em Paris. Seu primeiro livro publicado foi Yorubá Tal Qual se Fala, em 1950. Essa obra, que conta com um prefácio escrito por Jorge Amado e com ilustraçóes criadas por Carybé, marcou o início da carreira de Mestre Didi como escritor e estudioso da língua africana, com mais de 20 livros escritos e publicados. 
Eduardo Oliveira ${ }^{7}$ afirma que o candomblé é religião brasileira, "sob a hegemonia ora dos yorubás, ora dos jêjes, ora dos bantus” (2003, p. 90). Para o autor, os aspectos civilizatórios africanos podem ser melhor percebidos no candomblé: a síntese da cosmovisão africana, o sentido de Universo, de pessoa, de força vital, de palavra, de socialização, de morte, de família, de produção, de poder e de ancestralidade encontram-se sintetizados nas organizaçôes de tais religióes afro-brasileiras.

No item que transcrevemos, alguns desses aspectos são significativos. Por exemplo, a palavra ser criadora: Oxum falou e sua palavra determinou a mudança na realidade. A palavra na cosmovisão africana é, junto com a força vital, um elemento constitutivo da vida e da personalidade. Uma vez proferida, ela é energia e interfere na vida. Por isso é necessário que quem as pronuncia tenha conhecimento para fazer um bom uso, pois elas são capazes de engendrar coisas, tanto construtivas quanto destrutivas.

Percebe-se também a complexidade dos orixás. Eles, como qualquer pessoa, são complexos, têm características diversas e podem ser contraditórios. A psicologia ocidental, depois de tentar fazer muitas explicações de causa e efeito lineares, descobriu que os seres humanos são múltiplos, complexos, como na cosmovisão africana. Oxum é ternura, mas no itam acima é força, e quando é necessário vai à luta. A lógica da tradição ocidental onde o bem e o mal são separados é contraposta, pois as divindades sempre têm "qualidades" e "defeitos". O que é "qualidade" em determinado contexto pode ser "defeito" em outro e vice-versa.

Outra questão que emerge da história a que aludimos é relativa ao gênero. A óptica da cosmovisão africana expressa na narrativa é a da complementaridade entre o masculino e o feminino, sendo que a mensagem do itam é justamente essa: sem complementaridade, a estrutura do mundo se desorganiza. O mútuo reconhecimento do masculino e do feminino é necessário para as coisas irem bem para a comunidade. A organização do mundo matrilinear é revelada no enredo, onde governo só é possível com a legitimaçáo do feminino junto ao masculino. Reconhecida a legitimidade do princípio feminino, as assembleias ocorrem em paz e há o que comemorar. "A cosmovisão africana permeia o candomblé e favorece

7. Jovem filósofo que se dedica ao estudo e difusão da filosofia africana, atualmente professor da Universidade Federal da Bahia (UFBA), autor de Cosmovisäo Africana no Brasil: elementos para uma filosofia afrodescendente e de Filosofia da Ancestralidade. 
a inclusão, não a exclusão... as diferenças são aceitas" (OLIVEIRA, 2003, p. 89). Nilma Lino Gomes ${ }^{8}$ (2000) aponta a obra da americana Ruth Landes, $A$ cidade das mulheres (City of Women, 1947), como pioneira na análise antropológica do candomblé como culto guardado e preservado pelas mulheres: " $\mathrm{E}$ as mulheres têm tudo: os templos, a religiáo, os cargos sacerdotais, a criação e manutenção dos filhos e oportunidade de sustentarem a si mesmas" (LANDES apud GOMES, 2000, p. 232). O pioneiro estudo feminista de raça e de gênero aponta as relaçôes de reciprocidade no terreiro de candomblé que estuda, onde "para os homens o templo é um lar, lugar de calma e afeição com muitas mães que dão e recebem amor, que entretêm, alimentam e aconselham" (LANDES apud GOMES, 2000, p. 232).

Vamos a outra história que percorre o caminho de grupos culturais que inicialmente tiveram mais visibilidade no Brasil. Desta vez optamos por uma fábula com animais antropomorfizados:

\section{Nzamba ni Dizundu9}

Certo dia um Sr. Dizundu (sapo) falou à namorada do Sr. Nzamba (elefante) que este era o seu cavalo. Nzamba ficou sabendo do comentário e foi à casa de Dizundu tirar satisfações. Este, ao notar a chegada do outro, fingiu estar doente. Nzamba disse que não aceitava a ofensa e exigiu que fossem à casa de sua namorada para Dizundu para retirar o que havia dito. Este disse que estava muito doente, mas aceitaria. Começaram a caminhar, caminharam, caminharam um minuto, meia hora, uma hora e depois de uma hora e um minuto Dizundu disse que se sentia muito mal, que não conseguia mais caminhar e que deviam desistir. Nzamba aceitou levá-lo nas costas, até as proximidades da casa da namorada, desde que antes de chegar eles voltassem a caminhar lado a lado e a mentira fosse desfeita. Voltaram à estrada e Nzamba caminhou, caminhou por um minuto, caminhou por meia hora, caminhou por uma hora quando Dizundu disse que não conseguia se segurar no lombo de Nzamba, e pediu para passar uma corda pelos seus dentes, para se equilibrar. Nzamba negou, inicialmente, mas acabou convencido pela quantidade de argumentos de Dizundu.

8. Professora da Universidade Federal de Minas Gerais (UFMG) e coordenadora do Programa Açóes Afirmativas na UFMG e do NERA - Núcleo de Estudos e Pesquisas sobre Relações Raciais e Ações Afirmativas. Nilma desenvolve estudos na área de Educação e Antropologia, com ênfase em Antropologia Urbana, com temas como organização escolar, formação de professores para a diversidade étnico-racial, movimentos sociais e educação, relaçôes raciais, diversidade cultural e gênero.

9. Adaptado de Cascudo, 1984, p. 159. 
Novamente retomaram a estrada e Nzamba pôs-se a caminhar. Caminhou por um minuto, caminhou por meia hora, caminhou por uma hora, e após uma hora e um minuto Dizundu começou a reclamar de picadas de insetos e pediu a Nzamba que Ihe alcançasse uma pequena vara para espantar os mosquitos. Nzamba não aceitou. A conversa se repetiu como da outra vez e alguns instantes de fala bastaram para Dizundu convencer Nzamba, com o combinado que chegando perto da casa da namorada Dizundu desceria e chegariam caminhando lado a lado. Nzamba voltou a caminhar, caminhou por um minuto, caminhou por meia hora, caminhou por uma hora e já estavam próximos à casa de sua namorada. Dizundu começou a contar histórias para distrair a Nzamba e, sem que este percebesse, chegaram às proximidades da casa de sua namorada. Ao avistar a namorada, Dizumbu gritou: veja, o Sr. Nzamba é mesmo o meu cavalo. Os animais que estavam por perto riram muito e foi Dizundu quem se casou com a desejada namorada.

Entrou por uma porta, saiu por um canivete, mandou um rei Nagô que vocês me contem sete.

A origem dessa história é Bantu. Renato Mendonça (1935) a havia registrado como "conto brasileiro de Sergipe", tendo como personagens um cágado e um teiú. O próprio Cascudo citara uma variante "entre os sudaneses" 10 onde é a tartaruga quem cavalga o elefante. Este enredo também foi assumido por outros animais no Brasil. Recentemente, encontrei um exemplo num livro publicado em Cuiabá onde um macaco cavalga uma onça. $\mathrm{O}$ sapo e a tartaruga são animais muito presentes em fábulas de várias regióes da África negra, sempre com o sentido que ouvimos acima, de sagacidade e inteligência, sendo o coelho outro animal que rivaliza em importância. No Brasil, várias nações indígenas também mantinham entre suas fábulas sentido similar para a tartaruga (CASCUDO, 1984). Uma hipótese para a difusão da versão com o cágado no Brasil é a intertextualidade entre as habilidades atribuídas à tartaruga, tanto na tradiçáo africana quanto na tupi-guarani. $\mathrm{O}$ macaco, por sua vez, é símbolo de esperteza para o europeus, portanto as versôes em que

10. A palavra sudão tem originalmente o significado de região de transição entre o deserto e a floresta. Refere-se a toda a faixa em torno do deserto, sendo que no sul do Saara vai do ocidente ao oriente da África. Não se refere ao país que hoje denomina-se Sudão, que adotou este nome após a descolonização da África, no século XX. O próprio país tem uma faixa de sudão, ou savana, e localiza-se na parte mais oriental do continente, ao sul do Egito. 
ele aparece são influenciadas pela tradição de Portugal. A circulação da literatura oral rompe fronteiras, e o trabalho de pesquisadores detalhistas como Câmara Cascudo nos ajuda a conhecer com mais detalhes as origens das narrativas.

Por outro lado, Cascudo deve ser observado com um olhar crítico, principalmente no que diz respeito à descrição das relaçóes raciais no Brasil e às religiōes afro-brasileiras. No que se refere às relaçóes raciais, o autor apresenta um ponto de vista "cor de rosa", dando ênfase aos espaços de integração. No caso das religiôes afro-brasileiras, ele tem tendência a "folclorizar", no sentido de atribuir uma posição subalterna, de colocar como expressão de excentricidade, minorando os importantes aspectos da alteridade. As críticas podem deixar de reconhecer as contribuiçóes do autor. No que se refere à alteridade da população negra brasileira, Cascudo anotou uma versão corrente sobre a morte de Zumbi (CASCUDO, 2002), onde o guerreiro se joga do penhasco para não se deixar capturar, e sobre a importância da rainha Nzinga (CASCUDO, 2001) e de Chico Rei (CASCUDO, 2002).

Um aspecto a comentar sobre a história é o uso do artifício de contar o tempo em "partes" de ordem sucessiva, utilizado como recurso da narrativa para comunicar à audiência a passagem de tempo. É comum o uso sucessivo de um dia, uma semana, um mês ou um ano como recurso narrativo para dar a impressão de longa duração dos períodos.

A conclusão da história com um pequeno verso, recitado pelo narrador, indica a chegada ao fim. Esta estratégia é muito divulgada com o célebre "entrou por uma porta, saiu por outra, quem quiser que conte outra". Encontramos algumas versôes que grafam na segunda estrofe "el-Rei”, clara alusão à coroa portuguesa, mas optamos por outras que são relacionadas à tradição afro-brasileira (no itam sobre Oxum, Mestre Didi, na segunda história, rei Nagô). No segundo caso, o verso, além de marcar o final, convida os presentes a montarem uma roda de "contação de histórias" e contribuírem com alguma de seu repertório. É um formato muito comum mas não necessário. Estas formas não são rígidas, e os contadores normalmente utilizam-se de alguma situação do contexto para montar um verso com rima simples.

Passemos à outra história. Esta é de um povo que se autodenomina !Kung (o sinal ! indica um estalo labial antes da letra K). Em português, encontramos duas formas de denominá-los: boximanes ou bosquímanos ${ }^{11}$.

11. Do inglês bush men, homens arbusto, em alusão à sua baixa estatura. 
Estes viviam em áreas do sul da Angola até o Cabo da Boa Esperança. Representaram um percentual diminuto dos escravizados trazidos ao Brasil.

Havia uma grande variedade linguística relacionada à diversidade de territórios que ocupavam. Não havia demarcaçáo de terras, mas cada comunidade ocupava determinada região, onde viviam dos recursos naturais existentes. Dentro dessas vastas áreas, praticavam hábitos nômades, movendo-se de acordo com as estaçóes do ano, mudanças climáticas e consequente oferta de alimentos. Eram de hábitos preponderantemente vegetarianos, e a carne entrava como complemento alimentar, proveniente da caça, sendo esta prerrogativa dos homens. Os papéis sociais tinham nítidas divisóes entre homem e mulher, a esta cabendo o recolhimento de sementes e raízes (as quais conheciam profundamente), o preparo dos alimentos e a construção das cabanas. A mulher era uma companheira, não serva do homem. A organização social dos !Kung é de tipo horizontal, não prevendo poderes superiores. $\mathrm{Na}$ língua $\mathrm{Xam}^{12}$, de onde provém a história que vamos "escutar", não havia qualquer palavra para exprimir a ideia de chefe ou comandante. A colonização das terras da África Austral significou o extermínio das formas de viver e da maior parte dos grupos !Kung. Os remanescentes foram impelidos para as regióes mais inóspitas e atualmente ocupam, principalmente, certas partes do deserto de Kalahari. Hoje muitos jovens não têm possibilidade de manter os traços culturais de seus antepassados, sofrendo com a aculturação, sobrevivendo de doaçôes de milho feitas pelo governo para evitar as migraçóes e tendo no álcool uma forma de compensar a perda de identidade e dignidade (semelhanças com grupos indígenas brasileiros não são mera coincidência). Contar e recontar histórias é, também para os !Kung, um ponto de distinção de sua cultura, além de meio de transmissáo do ordenamento social e do conhecimento dos hábitos e costumes de seus antepassados. As histórias falam de entes da natureza, da luta para manter a sobrevivência contra as hostilidades do ambiente (os ventos, as tempestades, a fome, a sede etc.), e dos sentimentos relacionados a estes eventos (medo, ódio, amor, união etc.). Suas histórias estão repletas de figuras arquetípicas importantes, algumas com traços

12. A obra que utilizamos como fonte foi Fiabe Boscimane, organizada por Anna Meda, publicada em Milão pela editora Oscar Mondadori, em 1999. A autora realizou pesquisa sobre fábulas !Kun nas "Universidade da África do Sul e Universidade da Cidade do Cabo, e recolheu seu material na "coleção Bleek". O grupo "Xam" ocupava as terras da região do Cabo da Boa Esperança antes da chegada dos europeus. A narrativa que se seguirá, como todas as desta coluna, são o (re) contar desde autor, e não a tradução do original. 
comparativos às tradiçóes de culturas ocidentais e/ou pré-colombianas, como o controle do fogo e os papéis da Lua e do Sol. Entre os !Kung, contar histórias é uma arte que se faz com o corpo todo, onde a narrativa é enriquecida pelo gesto e pela expressão corporal. As imitaçôes de animais e de personagens, em geral, são feitas com modulaçóes de diferentes vozes e com a mais completa imitação corporal.

\section{A lua, a lebre e a origem da morte:}

Nossa história se passa há muitos, mas muitos anos mesmo atrás. Antes que a avó da bisavó da sua tataravó viesse para este mundo. Era mesmo o princípio do princípio dos tempos, o período mítico da primeira estirpe, quando com os primeiros homens e mulheres, viviam juntos os animais, e mesmo com os entes da natureza, como a lua e as nuvens. Estes também, neste início dos tempos, eram homens e mulheres, manifestavam sua natureza humana livremente e também tinham poderes mágicos.

Nesse tempo, quando estes primeiros homens e mulheres habitavam a terra, a deusa Lua decidiu enviar um importante aviso à humanidade: havia uma jovem lebre que havia perdido sua mãe. A Lua escolheu-a como mensageira, chamou-a e disse:

- Você está chorando muito, pois imagina que não verá sua mãe de novo. Mas eu, a Lua, te digo que pare de chorar, porque sua mãe reviverá amanhã mesmo. Como eu, que morro e renasço, assim acontecerá para todos os seres viventes. Como eu, todos podem retornar após a morte. Vá e dê esta mensagem a todos, mas primeiro aos doentes.

A lebre não prestara atenção e não escutava nada. Só continuava a chorar. A Lua falou a ela mais uma vez:

- Escute, pequena, você que tem essas orelhas tão grandes deve me escutar. Não é necessário chorar desta maneira. Eu, que sou a Lua, todos os dias morro, para fugir dos raios do Sol que podem me perfurar como um martelo. Mas no dia seguinte volto a nascer, e é meu desejo que assim ocorra com todos os seres vivos, que revivam após a morte. Pare de chorar, pequena, que amanhã poderá ver a sua mãe outra vez. Os animais morrem e se desfazem porque são feitos de carne e caminham sobre a terra, mas eu te digo que todos renascerão como eu mesmo. Vá e dê a notícia a todos os animais.

A lebre saiu, mas mal havia prestado atenção às palavras da Lua, e não acreditava na ideia de renascer. Ela chegou a todos os viventes, homens e animais, e disse:

- A Lua manda dizer que, como ela que morre e perece, assim será com todos, que morrerão e perecerão para todo o sempre. 
Quando a lebre retornou, a Lua perguntou sobre a mensagem. Escutando que a lebre tinha mudado a mensagem exatamente para o seu contrário, a Lua ficou furiosa. Havia enviado uma mensagem agradável, mas todos receberam uma mensagem ruim devido à mudança feita pela lebre.

Decidiu aplicar uma punição à lebre: pegou um ferro em brasa e acertou a boca da lebre, que para sempre ficou com os lábios separados, e falou:

- De hoje em diante não estarás mais entre os homens, e ao invés de ter as características humanas, será um animal selvagem, uma verdadeira lebre com esta marca nos lábios. E todos os outros animais te seguirão e morrerão, e não restará vida após a morte, inclusive os homens sofrerão para sempre por sua causa.

Assim começou a separação entre os entes do céu, que morrem e nascem, e os animais e homens, que morrem e perecem.

Entrou na perna de um pinto, saiu na perna de um pato, mandou a rainha Nzinga que vocês me contem quatro.

Qual o sentido de contar histórias como a desta tradição para os objetivos anunciados na introdução? O primeiro sentido é estético: as narrativas!Kun encantam os ocidentais há quatrocentos anos em função da sua beleza e lirismo. O segundo sentido é reconhecer a diversidade na África e na diáspora: povos como os iorubás e os !Kung tinham poucas possibilidades de contato, pois ocupavam áreas muito distantes na África, e, em geral, indivíduos de grupos táo diversos como estes foram tratados de uma forma, além do desumano da escravidão, generalista a ponto de perder de vista qualquer possibilidade de reconhecer sua diversidade. $\mathrm{O}$ terceiro sentido é a busca dos elementos da cosmovisão africana citados por Eduardo Oliveira, e neste caso, a importância da palavra é novamente tematizada: a maldição caiu sobre a lebre e animais porque ela não soube usar a palavra de forma responsável, e pela palavra a Deusa Lua anunciou o destino da humanidade.

Vamos a outra história, de outra nação, uma história etíope ${ }^{13}$ : 


\section{Não se pode viver sem um outro.}

Havia um sábio em um povoado da Etiópia, e todas as pessoas da região iam até ele com suas dúvidas, e ele sempre tinha uma resposta que as ajudava. Para as perguntas mais variadas, sobre os problemas mais diversos, ele sempre tinha uma boa resposta. Problemas como pessoas esquecidas, maridos ciumentos, educação das crianças, entre outros, sempre encontravam resposta sob medida.

Um dia o sábio chamou todas pessoas do povoado, e uma multidão se colocou diante dele. Ele então falou:

- Escutem, meus amigos e irmãos. Todas as pessoas destas bandas vêm a mim para pedir conselhos sobre os assuntos mais diversos, e eu sempre estou aqui pronto a ajudá-las com minhas palavras. Da pergunta mais tola à mais difícil, todas sempre tiveram uma resposta, um meio de ajudar a encontrar a solução para o problema levantado. Agora, sou eu que tenho uma pergunta a vos fazer e preciso de sua ajuda para uma questão para a qual não tenho a resposta.

- O homem que escreve a lei sabe que todos os homens foram criados iguais e que são tratados do mesmo modo diante da justiça. Mas eu, pessoalmente, estou em desacordo com esta lei. Eu afirmo que nem todos os homens foram criados iguais. As leis deviam tratar pessoas diversas de forma diversa. Espírito e matéria diferem de homem para homem.

- As diferenças existentes fizeram com que cada um fizesse um caminho, e é por isso que demos e sentimos as catástrofes criadas pelo homem. É por isso que os homens estão combatendo guerras sem solução. É por isso que escutamos falar em crimes em todos os lugares, e às pessoas falta paz nas mentes.

- Todavia, não há nada para maravilhar-se. Devemos ter a coragem de enfrentar a realidade da existência. Devemos tratar de resolver os nossos problemas sem andar por aí a pedir conselhos. Mas em tudo isso tem também uma verdade: que ninguém pode viver sem os outros, porque todos nós dependemos uns dos outros.

Se todos têm necessidade do conselho de um sábio, também o sábio tem necessidade do conselho de todos.

Novamente a intenção foi de informar sobre a diversidade da África, mais que retratar os povos que enfrentaram a diáspora, pois é pouco provável que etíopes tenham vindo ao Brasil na condição de escravos. 
O conteúdo é muito pertinente para a discussão sobre os direitos das minorias e significativo para a reflexão sobre políticas afirmativas que se fazem presentes na atualidade. A ideia de equidade era discutida no cotidiano das famílias etíopes por meio de histórias com mensagens de valores, como a que ouvimos.

As histórias etíopes são curtas e com mensagem moral bastante explícita, onde o final traz uma mensagem para refletir, o que era uma forma de educação de valores para crianças e jovens. Contadas à hora das refeiçôes do entardecer, eram invariavelmente recontadas e discutidas a seguir. Os etíopes se orgulhavam de ser um povo sem desajustados ou criminosos e creditavam o fato à educação moral de seus filhos por meio das histórias. O aprendizado moral com as histórias é, segundo os etíopes, a razão pela qual são muito reflexivos, sendo difícil um etíope agir de forma incorreta ou impulsiva. Nos séculos XVIII e XIX os europeus perguntavam espantados aos etíopes como não tinham cadeias. Os etíopes respondiam de uma forma singela: "Para que cadeias? As pessoas são educadas!". "Educadas como?", voltavam a perguntar os europeus. "Educadas pelas histórias contadas e recontadas todos os dias", respondiam os etíopes. Portanto, é possível notar que eles possuíam um fabulário riquíssimo e com papel social central na formação dos cidadãos.

A Etiópia teve uma organização bastante antiga em forma de império. $\mathrm{O}$ país resistiu à expansão islâmica e foi o que mais resistiu à colonização. Nos mapas do início do século XX, vemos a África repartida em domínios europeus, à exceção da Etiópia, que havia derrotado a Itália em 1889 e manteve-se independente até 1936, quando foi invadida pelo regime fascista de Mussolini, e o Rei Tafari (ou Ras-Tafari, cujos discursos contra os horrores da guerra e pela humanização foram inspiradores de movimentos pacifistas em todo o mundo e do movimento cultural que leva seu próprio nome) fugiu e se abrigou na Inglaterra. Como país muito antigo e reconhecido como reino importante ao sul do Nilo desde os primórdios da Grécia, é bem provável que o contato com a Europa, por via do Egito, e com a Ásia ocorreu desde épocas remotas. A interinfluência na literatura oral também é muito provável. As fábulas etíopes compuseram, com as histórias d'As Mil e Uma Noites, as fábulas de Esopo, um conjunto de narrativas europeias que tem como pilares essas fábulas e histórias (MENGHESCA, 1993).

Mesmo em uma civilização com tantas particularidades, pode-se encontrar aspectos que reforçam a ideia de cosmovisão africana com pontos 
de convergência para diversas culturas da África negra. No caso da história em questão, o reconhecimento da diversidade humana é um ponto crucial para o nosso momento político. A mensagem política de organização social que promove a participação é clara, pois os sábios precisam do conselho de todos. Além disso, novamente se revela a importância da palavra na formação do homem e na organização da realidade.

A literatura oral afro-brasileira e africana é um campo a ser explorado e degustado, devido a sua riqueza, amplitude, beleza e energia. As fontes possíveis são variadas. Infelizmente, temos pouca bibliografia especializada a este respeito publicada no país, mas uma volta pelas livrarias já é suficiente para perceber diferenças em relação às últimas décadas, pois passamos de raríssimos títulos para "alguns". Outras fontes, como livros de história, biografias e livros de viagem podem ser utilizadas tanto para a criação de contos orais quanto para o enriquecimento das informaçóes acessórias.

O uso da cultura popular como forma de orientar o currículo (da forma como indicam os teóricos da resistência) já foi descoberto e tematizado no Brasil, mas falta irmos além de experiências localizadas, como a da Escola Tia Ciata no Rio de Janeiro (LEITE, 1991), do Projeto Axé (VILANOVA, 1999; REIS, 2000) em Salvador, da Mini Obá Biyi (LUZ, 1997) na mesma cidade. Nossa proposta é instrumentalizar a nós mesmos e aos professores e alunos da escola brasileira, no sentido de buscar e difundir histórias de nosso povo negro, africano e brasileiro. Um aspecto significativo é nos colocar como protagonistas, o uso do "nós", negros, no lugar do lugar de "eles" ou "outro", que nos têm sido reservado.

A “contação" de histórias de origem africana pode servir de apoio para o processo da "alfabetização da diáspora" necessária, isto é, para desenvolvermos em nós e em nossos alunos, negros e não-negros, habilidades de leitura de signos culturais relativos a nossa herança africana. Os aspectos estéticos e lúdicos das narrativas são elementos que contribuem para a afirmação da identidade e para a estruturação da alteridade. As narrativas em si não significam a mudança, mas sua problematização pode servir a um projeto de educação multirracial embasado numa perspectiva crítica, que não se conforme com o multiculturalismo fácil e retórico e com a perspectiva assimilacionista do "cadinho das raças”. As fábulas e histórias afro-brasileiras podem ajudar a ir além das 
narrativas limitadoras da cultura europeia, como modelo de civilização e progresso, e a problematizar a promessa emancipatória de pluralidade, como base para novas formas de solidariedade e cultura pública que presentes em muitas propostas multiculturais. A análise das histórias também pode focar a possibilidade dos alunos elaborarem a noção de "branquidade" e o correlato estabelecimento de uma cidadania cultural que afirme a diferença, que náo categorize o Outro como objeto de avaliação.

Dentro do discurso da modernidade, as abordagens educacionais dominantes à raça e à etnicidade imitam muitas das piores dimensóes da ideologia liberal e do essencialismo radical. As questóes do Outro são em geral moldadas no discurso da educação multicultural, que em suas formas e abordagens variadas em geral não conseguem conceituar as questóes de raça e etnicidade como parte do discurso mais amplo do poder e de privação do poder. As questôes de representação e inclusão suprimem quaisquer tentativas de questionar a norma da brancura como uma categoria étnica que garanta sua dominação por dar a impressão de ser invisível [...] Está faltando aqui uma tentativa de criticar as formas de cultura europeia e norte-americana que situam a diferença nas estruturas de dominaçáo ou reconstroem um discurso de raça e etnicidade em uma teoria da diferença que dá destaque às questóes de igualdade, justiça e liberdade como parte de uma luta democrática contínua. (GIROUX, 1999, p. 139-140).

Por um lado, defendemos a hipótese que a valorização da cultura africana e, em específico, dos mitos, fábulas e histórias afro-brasileiras é um instrumento para a ressignificação necessária do que é ser negro no Brasil. Por outro, nossa proposta é pensar na alfabetizaçáo da diáspora aliada à crítica que reconhece a "branquitude" como categoria cultural e política. Julgamos que as fábulas e mitos afro-brasileiros podem ser pertinentes nesse sentido, particularmente no que se refere ao alunado branco e a construção da noção de "branquitude".

Entrou por uma porta, saiu por outra. Agora você - me conte outra! 


\section{REFERÊNCIAS}

ADÉKÒYÁ, O. A. Yorubá: tradição oral e história. São Paulo: Terceira Margem, 1999. (Coleção África).

CASCUDO, L. C. Literatura oral no Brasil. 3.ed. Belo Horizonte: Itatiaia/São Paulo: Edusp, 1984.

Made in África (pesquisa e notas). São Paulo: Global, 2001.

Lendas brasileiras. Rio de Janeiro: Ediouro, 2002.

GIROUX, H. A. Redefinindo as fronteiras da raça e da etnicidade: Além da Política do Pluralismo In: Cruzando as fronteiras do discurso educacional: novas políticas em educação. Porto Alegre: Artes médicas, 1999, p.133-172.

GOMES, N. L. Caminhando com Ruth Landes pela Cidade das Mulheres. In: FONSECA, M. N.; SANTOS, J. (Orgs.). Brasil afro-brasileiro. Belo Horizonte: Autêntica, p. 60-68, 2000.

GUIMARÃES, A. S. A. Classes, raças e democracia. São Paulo: Editora 34, 2002.

LEITE, L. C. A magia dos invencíveis: os meninos de rua na Escola Tia Ciata. Petrópolis: Vozes, 1991.

. É possível a volta para a escola. Educar. Curitiba, n.15, p.73-82, 1999.

LUZ, N. O Patrimônio civilizatório africano no Brasil. Revista do Patrimônio Histórico e Artístico Nacional. Dossiê Negro Brasileiro Negro. Brasília: IPHAN, n.25, p.199-209, 1997. MEDA, A. Fiabe Boscimane. Milano: Mondadori, 1999.

MENDONÇA, R. O negro no folk-lore e na literatura do Brasil. In: ESTUDOS AFROBRASILEIROS, 1, 1934, Recife. Congresso Afro-Brasileiro. Rio de Janeiro: Ariel, p. 1-16, 1935, (Edição da Fundação Joaquim Nabuco, 1988).

MENGHESCA, S. (Org.). Fiabe Etiope. Milano: Mondadori, 1993.

NORVELL, J. M. A brancura desconfortável das camadas médias brasileiras In: RESENDE, C. B.; MAGGIE, Y. (Orgs.). Raça como retórica: a construção da diferença. Rio de Janeiro: Civilização Brasileira, p. 245-265, 2001.

PETROVICH, C.; MACHADO, V. Ilê Ifề. O sonho do Jaô Afonjá (mitos afro-brasileiros). Salvador: EDUFBA, 2000.

OLIVEIRA, E. Cosmovisáo Africana no Brasil: elementos para uma filosofia afrodescendente. Fortaleza: LCR, 2003.

REIS, A. M. B. (Org.). Plantando axé: uma proposta pedagógica. São Paulo: Cortez, 2000.

RISÉRIO, A. Oriki Orixá. São Paulo: Perspectiva, 1996.

SKIDMORE, T. E. Preto no branco: raça e nacionalidade no pensamento brasileiro. Rio de Janeiro: Paz e Terra, 1976. 
TELLES, E. Racismo à brasileira. Rio de Janeiro: Relumé Dumará: Fundação Ford, 2003.

VILANOVA, E. C. A. A relação educador-educando no projeto axé. Educar. Curitiba, n. 15, p. 155-162, 1999. 


\section{CRIANÇAS NEGRAS NAS IMAGENS, IMAGENS DE CRIANÇAS NEGRAS: INFÂNCIA E RAÇA NA ICONOGRAFIA DO SECULO XIX}

Ione da Silva Jovino Universidade Estadual de Ponta Grossa

Criança, Infância, Raça, História e Iconografia

Se fosse sobre crianças de rua, ia ser tudo negra.

A frase acima foi dita por uma criança de aproximadamente oito anos, há alguns anos atrás. Ela reflete a insatisfação da criança diante de um programa de televisáo para a qual ela se programou durante muitos dias para assistir. As chamadas conclamavam todas as crianças a participarem de um dia especial sobre as crianças no mundo, um dia internacional das crianças na televisão. Entre outras coisas, essa fala reflete o que muitas pesquisas na área de educação vêm apontando: a necessidade de que as crianças se reconheçam nas referências visuais que têm. Ao desprezar a diversidade étnico-racial com relação ao universo infantil, a programação fez com que uma criança se sentisse prejudicada em relação a sua própria imagem e analisasse que as imagens de crianças negras são usadas para ilustrar questôes muito específicas, de preferência ligadas a mazelas sociais, mas não para fazer parte do prazer de um dia internacional das crianças na televisão.

Uma educação comprometida com a autoestima e autorrepresentação positiva das crianças, em especial das crianças negras ${ }^{1}$, pode encontrar

1. Romão (2001) tem um ensaio sobre o tema no qual discute o papel da educação e sua relação com a autoestima da criança negra, ressaltando a importância da contextualização histórica do tema. 
um caminho na discussão crítica dos discursos sobre as crianças por meio de imagens. Dentre os diversos caminhos que poderíamos tomar para isso, proponho a busca pela configuração dos discursos sobre as crianças negras por meio de imagens, com base em estudos sobre imagens de negras e negros no século XIX e em outros sobre o contexto histórico no qual foram produzidas tais imagens.

Para início de conversa, convém retomar a relação entre as imagens, a ideia de raça e como foi construída no século XIX, especialmente a partir do olhar europeu, oportunamente lembrada por Santos (2002). A autora aponta que tanto nas ciências quanto nas artes, a imagem do negro que é veiculada leva a crer numa inferioridade inata e irremediável. Sobre as imagens de pessoas negras produzidas no período, pode-se ressaltar que um dos registros preferenciais foi sobre as diferenças visíveis que caracterizavam a população de origem africana que vivia no Brasil da época.

Conforme Kossoy e Carneiro (2002), com a chegada da corte portuguesa em 1808, os portos do Brasil se abrem ao olhar estrangeiro. Esta é a época da chegada de naturalistas de diferentes nacionalidades, mas sempre homens, brancos e europeus. Estes já traziam consigo imagens préconcebidas do que iriam registrar, portanto não apresentam imagens neutras.

Os relatos e imagens buscavam registrar as diferenças étnicas, por meio dos traços fisionômicos, cor da pele, sinais no rosto e até mesmo de caráter e temperamento. As marcas de propriedade ferradas na pele também aparecem nos registros como reveladoras de identidade, em especial como observado nas mulheres pelo modo com que ornam o corpo com penteados e panos.

Essas imagens nos dão a ver muitas crianças em algumas situações. Mais comum que a presença das crianças nas imagens, é o silêncio sobre elas nas análises apresentadas, mesmo quando são apresentadas as fotos em que as mulheres negras trazem crianças amarradas às costas ou ao colo.

Desde os trabalhos de Mott (1979) e Mattoso (1988), poucas pesquisas enfocaram a criança e a infância negra no século XIX. Além disso, a maior parte da bibliografia sobre negras e negros na escravidáo narram historias de adultos, como se não existissem crianças ou fossem apenas apêndices.

A respeito de criança e infância, é importante salientar que estas são noções construídas histórica e socialmente, que mudam ao longo do 
tempo e se encontram em permanente reelaboração. Do ponto de vista da sociologia da infância, a criança e a infância são construçóes produzidas a partir das práticas sociais e desta forma não podem ser vistas como únicas e universais, mas plurais: infâncias e crianças, e esta pluralidade, do ponto de vista de alguns autores, deve ser entendida enquanto uma multiplicidade que pode ser cartografada. Afasta-se, assim, da visão biológica que vê a criança como um corpo único, com características universais. Neste caso, temos a passagem de uma visão que pensa a criança para uma que vê uma criança: da criança única e universal para uma criança impessoal, singular e múltipla.

É possível trabalhar com imagens de crianças e com os indícios de infância, elementos da cultura atribuídos às crianças, levando em conta que os seres humanos transitam por duas linhas não excludentes: a infância como tempo cronológico e a infância como experiência de vida. A ideia de busca de indícios de infância está ligada ao conceito de "sentimento da infância”, com base no que foi definido por Ariès (1981). Para o autor, o sentimento da infância não significa o mesmo que afeição pelas crianças, mas corresponde à consciência da particularidade infantil, ou seja, ao que distingue essencialmente a criança do adulto ou do jovem.

Pensando na multiplicidade de usos das imagens contemporaneamente, como instrumentos de legitimação de uma memória negada, ou na manutenção de registros, um exemplo vem à tona: Müller (2008) mostra a partir de fotografias como a população negra se fez presente no contexto das escolas, seja pela presença de professoras e professores negros, seja pela presença de alunas e alunos negros na Primeira República (1889-1930). Ao mesmo tempo em que investiga essa presença, Müller (2008) também se questiona quanto ao apagamento simbólico de negros profissionais da educação entre os anos de 1889 e 1930.

Em outro caso, com outras circunstâncias e outra abordagem, Oliveira Silveira (2003), poeta, ativista e uma das grandes figuras dos movimentos sociais negros brasileiros, busca a historicidade do dia 20 de novembro como dia nacional da consciência negra, invocando as atividades do grupo Palmares, realizadas em Porto Alegre entre 1971 e 1977, em recortes de jornais e outros materiais de divulgação: cartazes, folders, filipetas e, sobretudo, fotografias. Oliveira constrói um texto conciso, curto e contundente sobre a mobilizaçáo, organizaçáo e construção de uma prática política não convencional, recuperando memórias postas às margens na 
construção da história nacional. Por meio da história do grupo Palmares, foi possível ter mantido parte da história visual da luta negra no Rio Grande do Sul, legitimando um pioneirismo na organização do movimento negro e na construçáo dos significados do dia 20 de novembro.

Olhar as imagens separadas ou em conjunto, como texto, como objeto de significação e comunicação, como algo que é dado a ver e como arte pode ser um exercício de entender o que está dado a ver e o que náo está. Como resultado da leitura de imagens como narrativas, buscando compreender quais discursos elas constroem, podemos, por exemplo, rever as já tão vistas imagens de Debret.

No estudo sobre imagens de crianças negras no século XIX (JOVINO, 2010), tivemos como objetivo analisar fontes iconográficas, considerando-as a partir de suas potencialidades como fontes históricas e documentais, classificando e estabelecendo ligaçóes entre as mesmas e as práticas e saberes dos contextos em que foram produzidas. Tal relação busca garantir, conforme Gouvêa (2006), a historicidade da análise, para não criar um vazio entre a mesma e o contexto histórico em que foram produzidas as obras.

Cabe ressaltar que a pesquisa partiu do reconhecimento da existência de um sentimento sobre a infância, que segundo Ariès (1981), corresponde à consciência da particularidade infantil e da noção da raça como categorias analíticas importantes, e buscou configurar discursos sobre as crianças negras por meio das imagens, com base em estudos sobre imagens de negros no século XIX e outros sobre o contexto histórico no qual foram produzidas.

As imagens do século XIX, como as de Jean Baptiste Debret, ainda são impregnadas de visibilidades que precisam ser desconstruídas: a criançamacaco ou a criança-cachorrinho, que se alimenta dos restos embaixo da mesa do jantar e goza do mesmo "status" dos animais de estimação. Tais imagens são importantes pela ampla reprodução, seja em aberturas de novelas televisivas, ilustraçôes de livros didáticos ou em outras produçóes acadêmicas e artísticas pela constante referência a elas em estudos sobre o negro no século XIX e, principalmente, pelo fato de a representação das crianças passar quase despercebida pelas análises dessas imagens. Em parte delas, as crianças aparecem como parte do cenário do trabalho dos adultos: estáo no chão de terreiros de café ou das salas de costura nas quais os olhares dos adultos ou das crianças maiores estão voltados para as atividades do trabalho; estão nas salas de jantar, enquanto as negras e negros adultos cuidam da 
alimentação dos senhores, portanto trabalham; estão por ali sendo "mal acostumadas" com os restos do jantar, aprendendo, segundo Debret, a gulodice que os levaria, depois dos cinco ou seis anos, a "roubar as frutas do jardim" ou "disputar com pequenos animais domésticos os restos de comida"; estão ainda sob o cuidado de outras crianças, um pouco maiores.

Não só na contenda com animais domésticos por restos de comida a criança negra é desumanizada ou animalizada, mas também nas figuras disformes ou na proximidade com animais, e as imagens de Debret trazem essa comparação, isso quando ele não unifica crianças negras e animais textualmente, como na descrição das pranchas Jantar brasileiro, nas quais apresenta os negrinhos que distraem a senhora em substituição aos "doguezinhos já quase desaparecidos na Europa”, ou em Uma senhora brasileira em seu lar, na qual escreve sobre "dois negrinhos, apenas em idade de engatinhar e que gozam [...] dos mesmos privilégios do pequeno macaco" (DEBRET, 1989, p. 53).

Tais imagens fixaram uma forma hegemônica de projeção da escravidão, ou seja, quando imageticamente pensamos na escravidão, a concebemos quase sempre aprisionados por essas imagens. Sendo assim, uma das contribuiçóes deste trabalho é visibilizar maneiras pelas quais as crianças negras são dadas a ver por meio dessas imagens e, ao mesmo tempo, fazer esforço para fugir da maneira iconográfica pela qual as crianças negras são representadas na escravidão.

Esse processo de desconstrução e reconstrução somente é possível na medida em que se ampara em metodologias e recursos que advêm de áreas como a semiótica, a antropologia visual, a história cultural, dentre outras. A interface, entre diversas áreas, tornou possível o desafio de uma educadora compreender no tempo, diacrônica e sincronicamente, essas imagens como narrativa da história da infância negra no século XIX.

Todavia, Ariès trabalhou com uma determinada classe social, o que nos leva a considerar outros autores para justificar a busca de um "sentimento da infância negra”. Por exemplo, para Sarmento e Pinto (1997), nos estudos sobre crianças e infâncias os fatores de hetero e homogeneidade devem ser evidenciados. Para os autores, mais que uma distinção conceitual e terminológica, redundância ou sutileza analítica, evidenciar tais fatores é uma necessidade incontornável na definiçáo de um campo de estudos e de investigação. 
Ressaltam os autores que, além das diferenças individuais, o principal fator de heterogeneidade é revelado pelas condiçóes sociais, sejam elas de classe, étnico-raciais, de gênero ou culturais. Todavia, para os autores, a atenção aos fatores de heterogeneidade não podem ocultar os de homogeneidade. Com respeito às diferenças, este aspecto é o que contribui para a construçáo da infância como categoria social que se define pela idade e por fatores transversais às condições sociais, que permitem pensar na infância como categoria social que se distingue de outros grupos e categorias sociais ao mesmo tempo caracterizando-a como minoria. Tal perspectiva da infância, construída a partir dos anos de 1990 no domínio da sociologia da infância, aplica-se aqui para justificar o recorte etário e racial.

\section{Criança, infância e escravidão no século XIX}

Num primeiro momento da historiografia da escravidáo brasileira, as interpretaçóes economicistas obscureceram o conhecimento mais apurado das relaçóes entre os próprios escravizados, assim como destes com os libertos e os brancos pobres. Salvo raríssimas exceções, não houve silêncio nem invisibilidade maior do que aquela que incidiu sobre as mulheres e as crianças escravizadas. Isso é comprovado por um dos trechos do pioneiro trabalho de Mattoso (1988, p.38), que comenta a dificuldade de trabalhar com as fontes, no caso de inventários post-mortem, que náo deixam transparecer os aspectos da vida cotidiana, alegando haver um anonimato redutor na escravidão: "o que se pode dizer então das crianças escravas que são duplamente mudas e duplamente escravas?"

No entanto, essa historiografia conheceu mudanças significativas nas últimas décadas. Conforme Wissenbach (2002), pode-se destacar os enfoques interpretativos que consideram o escravizado como agente histórico, uma visão imprescindível para superar os pontos de vista tradicionais que insistiam na reificação e vitimização do cativo. Alguns artigos são importantes para a compreensão da mudança de perspectiva apontada por Wissembach (2002), dentre eles o de Schwartz (2001), que apresenta um estudo bibliográfico sobre a historiografia da escravidão brasileira, identificando autores, obras e debates. O autor também destaca como obras temáticas mais gerais como, por exemplo, a História das Crianças no Brasil, "torna a escravatura parte essencial da história da infância no país" (SCHWARTZ, 2001, p. 56). Embora toda pesquisa tenha seus limites, seria pertinente ressaltar que dos duzentos e sessenta e seis textos listados, 
citados e comentados por Schwartz (2001), apenas um faça referência à temática da infância.

Voltando para a perspectiva histórica sobre infância, o trabalho de Ariès (1981) nos mostra que aquilo que parecia um fenômeno natural e universal era resultado de uma construção paulatina das sociedades ocidentais modernas e contemporâneas. Segundo Pinto (1997, p.43):

[...] no sentido em que a entendemos hoje em dia, a infância constitui uma realidade que começa a ganhar contornos a partir dos séculos XVI e XVII, embora praticamente só nos últimos 150 anos adquira, de fato, expressão social, não só no plano da enunciação e dos princípios, como também, e sobretudo, no plano da prática social generalizada.

O uso de fontes iconográficas para os trabalhos sobre crianças e infâncias tem sido relevante para a constituição de um campo de estudos chamado história da infância. Especificamente sobre o trabalho com fotografias de crianças, Burke (2004) salienta que elas têm sido analisadas por historiadores sociais ocasionalmente, e que tem objetivado, acima de tudo, documentar a história da infância, ou, dito de outra forma, as mudanças nas visóes que os adultos têm das crianças, pois a produçáo material e simbólica sempre é sobre e para a criança, mas nunca de sua autoria. A especificidade dos estudos sobre infância seria, então, o recolhimento e análise dessas produçôes.

Ao que tudo indica, um dos primeiros trabalhos que teve como tema a criança negra no século XIX foi o de Mott (1979), onde a autora analisa cerca de oitenta obras da chamada "literatura de viagens", cujos autores estiveram no Rio de Janeiro entre 1800 e 1850, destacando "os dados referentes à situaçâo da criança negra, seja como 'mercadoria' recém-importada da África, seja como fruto da reprodução da população já escravizada” (MOTT, 1979, p.37).

Nove anos mais tarde, Mattoso (1988) aponta ser o trabalho de Mott (1979) o único que ela conhecia sobre o tema². Apoiada em três perguntas chave: o que se pode dizer das crianças escravas; com que idade e de que forma deixam de ser crianças e passam a ser escravas; e o que é a infância para a criança escrava, Mattoso (1988) discute, entre outros

2. O texto de Mattoso (1988) foi republicado em Del Priore (1991). Nesta mesma obra também consta o trabalho de Lima e Venâncio que aborda a temática. 
aspectos, as condiçôes de nascimento, crescimento, sociabilidade, iniciação ao trabalho e aprendizado das leis da escravidão para os filhos das escravas nas últimas décadas da escravidão baiana.

Após 1850, em função do fim oficial do tráfico, a maioria dos escravizados era composta não de africanos recém-chegados, mas de filhos, netos, bisnetos e tetranetos daqueles vindos principalmente da África centroocidental antes da interdição continental imposta pela Inglaterra. A garantia de geraçóes subsequentes é a única maneira de assegurar o desenvolvimento humano de determinada sociedade. Nesse caso, podemos supor que escravidão e parentesco sejam instituiçóes paradoxais, como propóe Meilassoux (1995).

Nesse contexto, a procriação dos escravizados passou a ter um caráter econômico que não existia antes de 1850 . Não era rara a existência de senhores que mantinham amplo concubinato com mulheres negras e/ou que incentivavam a união entre seus escravizados como tentativa de controle da fecundidade das escravizadas por meio do incentivo à procriação, tendo como contrapartida a manumissão.

Não obstante, é possível verificar altas taxas de mortalidade infantil ao longo de todo século XIX. Como indicam alguns autores, o tratamento dispensado às crianças filhas de escravizados sofreu uma drástica mudança com a proibição definitiva do tráfico. Tal mudança se refere ao fato de que "as peças perdidas" não seriam mais facilmente repostas, então passa a haver uma preocupação com a higiene e a saúde das crianças escravizadas, chegando, em casos extremos, à publicação de cartilhas de prescrição de cuidados com as mesmas.

Sobre o que acabamos de dizer, alguns aspectos relevantes podem ser destacados a partir do trabalho de Marquese (2004). Em um dos capítulos, o autor analisa manuais elaborados no Brasil com prescriçôes de modos de lidar com a escravaria, comparando os manuais brasileiros e seu contexto de produção com outras produçóes nas Américas. Verifica-se o que viemos a afirmar na análise que o autor faz dos manuais prescritivos escritos no Brasil Império, entre os anos de 1820 a 1860, pinçando aquilo que diz respeito à vida das crianças.

Para citar um exemplo, o manual de Carlos Augusto Taunay, exmajor napoleônico e ex-integrante do exército brasileiro, apresentou, na visão de Marquese (2004), a reflexão mais sistemática sobre a gestão escravista 
da primeira metade do século XIX. Seu grande objetivo era escrever sobre a conduta e disciplina dos escravos, fixando "princípios racionais para a administração dos cativos, passíveis de serem obedecidos em qualquer propriedade rural escravista no Brasil” (MARQUESE, 2004, p. 271).

Acreditando na suposta inferioridade da raça negra africana, e que a escravidáo era um fardo mais pesado para os senhores que para os escravizados, Taunay apostava numa espécie de "pedagogia do medo" para impor uma férrea disciplina, à base de coação, a fim de obrigar "os pretos a dar conta da sua tarefa”. Taunay também refletiu sobre a família e a gravidez, bem como sobre a educação das crianças pequenas: por um lado, propunha que as grávidas e parturientes fossem tratadas com cuidado e deslocadas para trabalhos mais leves, por outro, se preocupava igualmente com o fruto desses ventres. Desdobrava-se a preocupação com o ventre e o recém-nascido na atenção com as crianças até por volta de dez anos de idade. Para Marquese (2004), Antônio Caetano da Fonseca apresentou um projeto articulado sobre essa questáo, tratando da criação de escravos nascidos nas propriedades de acordo com os anseios dos seus senhores:

Assim, "no tempo da dentição", por se tratar do "tempo crítico da infância", toda atenção era necessária com a criança escrava: os maiores inimigos dos bebês, nessa etapa, as "lombrigas e diarreias", precisavam ser controlados com óleo de rícino e com uma alimentaçáo baseada em arroz, caldo de carne e mingau. Estando as crianças mais crescidas, as refeiçóes passariam a ser feitas em comum, com supervisão constante do senhor; aliás, nesse momento era fundamental que o senhor começasse a demonstrar grande afabilidade pelas crianças escravas, para que as mesmas adquirissem certo amor pelo seu proprietário. (MARQUESE, 2004, p. 291).

É importante ressaltar que, para Fonseca, o fato de as crianças adquirirem "certo amor pelo seu proprietário" tinha dupla função: a primeira dizia respeito às próprias crianças e se relacionava com o exposto por Taunay - a criação de uma geração mais dócil e adaptável, menos revoltosa e mais obediente; a segunda dizia respeito a seus pais, que vendo seus filhos "bem tratados" e gozando da "simpatia" de seus senhores, lhes criava "amor, por uma simpática retribuição" e, portanto, seriam mais fiéis e obedientes (MARQUESE, 2004, p. 292). 
A necessidade da instrução católica no cuidado com as crianças, juntamente com o restante das prescriçóes, denotavam o esforço para "crioulizar" os pequenos escravizados o mais rápido possível e diminuir seu potencial de rebeldia futura. Era corrente a crença de que os nascidos no Brasil, se fossem corretamente "educados", seriam mais disciplinados que os africanos. Alguns dos viajantes trariam passagens em seus relatos que demonstrariam a tal docilidade das crianças:

[...] Algumas das meninas tinham um ar muito doce e cativante. Apesar de sua pele escura, havia tanto recato, delicadeza e cordura nos seus modos, que era impossível deixar de reconhecer que eram dotadas dos mesmos sentimentos e da mesma natureza das nossas filhas.

[...] Uma das coisas que me chamou atenção ali foi um grupo de meninos que pareciam ter formado uma espécie de sociedade. Tive a oportunidade de observar várias vezes, ao passar pelo local, que esse grupinho se reunia sempre junto a uma janela gradeada. Pareciam muito ligados uns aos outros e sua bela amizade nunca era perturbada por brigas; na verdade, o temperamento de uma criança negra é geralmente tão equilibrado que ela não é afetada por essas ligeiras e mórbidas sensaçóes que frequentemente causam irritação e mau humor nas nossas crianças. (WALSH, 1985, p. 152).

Há que se salientar aqui uma controvérsia: alguns autores defendem a crença de que, durante a existência do tráfico transatlântico, existiria uma preferência por jovens e crianças justamente pela facilidade de adaptação e pelo menor potencial de rebeldia em comparação aos adultos ou crianças e jovens nascidos no Brasil. Mott (1979, p. 59) destaca, entre outros motivos, que a preferência por jovens e crianças era devida à "crença, geralmente difundida entre os senhores de escravos que os crioulos [...] eram menos dóceis e menos ativos". Mattoso (1988, p. 43) coloca essa observação de Mott em nota de rodapé. Contudo, Mott (1979, p. 79) observa que a condição da criança africana não sofria muita distinção: ela era tratada pela condição de escrava, assim como a criança crioula, e que nos relatos de viajantes, quando alguma distinção era feita, seguia uma tendência em ressaltar “o aspecto 'repugnante' e 'selvagem' do africano recém-chegado em contraposição à 'civilização' dos escravizados há mais tempo e principalmente dos mulatos". 
Alguns autores falam sobre "certa boa vontade das proprietárias com as crias de suas escravas", quanto a isso, observa-se os comentários de Debret sobre a gravura $O$ jantar brasileiro:

No Rio, como em todas as outras cidades do Brasil, é costume, durante o tête-a-tête de um jantar conjugal, que o marido se ocupe silenciosamente com seus negócios e a mulher se distraia com os negrinhos, que substituem os doguezinhos, hoje quase completamente desaparecidos na Europa. Esses mulecotes, mimados até a idade de cinco ou seis anos, são em seguida, entregues à tirania dos outros escravos, que os domam a chicotadas e os habituam, assim, a compartilhar com eles das fadigas e dissabores do trabalho. Essas pobres crianças, revoltadas por não mais receberem das mãos carinhosas de suas donas manjares suculentos e doces, procuram compensar a falta roubando as frutas do jardim ou disputando aos animais domésticos os restos de comida que sua gulodice, repentinamente contrariada, leva a saborear com verdadeira sofreguidão. (DEBRET, 1989, p. 60).

Já no século XVII, Ariès (1981) observa que a presença de crianças junto aos adultos, especialmente na mesa, não era bem vista, pois se acreditava que essa mistura tornasse as crianças mimadas e mal educadas. $\mathrm{O}$ olhar de Debret, mesmo dois séculos depois, talvez ainda guarde resquícios deste "sentimento da infância" descrito por Ariès.

Para Mattoso (1988, p. 52) os pequenos entre zero e três anos gozavam do privilégio de acompanhar suas mães ou outras escravizadas. $\mathrm{O}$ período seguinte, até os sete ou oito anos, seria o de "iniciação aos comportamentos sociais no seu relacionamento com a sociedade dos senhores, mas também da comunidade escrava”. Depois dessa idade, começarão a prestar serviços regulares como carregar instrumentos e materiais de trabalho das lavadeiras, ganhadeiras ${ }^{3}$, e outras. Também será utilizado pelos senhores para carregadores de todo tipo de objetos, como mensageiros, pajens, etc. Até os doze anos, serão transformados em aprendizes de alfaiate, sapateiro, ferreiro, serviços domésticos e costureira.

3. Podiam ser tanto mulheres negras livres ou forras que se utilizavam dos espaços urbanos para vender produtos e serviços para seu sustento e de seus filhos ou parentes, quanto escravizadas obrigadas a dar a seus senhores uma quantia previamente combinada de seus ganhos, ficando o excedente para elas. Ver, dentre outros, SOARES, C. M. As ganhadeiras: mulheres e resistência negra em Salvador no século XIX. Afroasia. Salvador: UFBA. n.17, p.57-71, 1996. 
A preparação da criança negra para o trabalho no universo da escravidão começava muito cedo. Desde muito pequenas, elas eram encarregadas de realizar pequenas tarefas domésticas, e no caso daqueles meninos, alguns serviços de rua também. Além disso, as imagens de Debret, bem como algumas fotografias, nos deixam ver os pequenos sempre próximos dos adultos negros no trabalho, o que indica que a educação para o trabalho apontada por Fonseca (2002) se daria também pela observação e pela convivência com os mais velhos durante seus afazeres.

Florentino e Góes (2005) apresentam um dos poucos trabalhos, posteriores aos de Mott (1979), Mattoso (1988), Lima e Venâncio (1991), em que criança e infância, escravizadas ou não, e crianças negras e suas modalidades de existência fazem parte do objetivo central das análises.

Os autores observam que desde muito cedo as crianças aprendiam que "o ingresso no mundo dos adultos se dava por outras passagens: em vez de rituais que exaltavam a fertilidade e a procriação, o paulatino adestramento no mundo do trabalho e da obediência ao senhor", logo, aprenderiam a ser uma criança escrava (FLORENTINO; GÓES, 2005, p. 209).

$\mathrm{O}$ texto se refere privilegiadamente "às crianças que viveram e morreram nas áreas rurais do Rio de Janeiro” entre 1790 e 1830 . Neste período, a população escrava representava metade dos habitantes rurais, sendo parte daqueles com idade maior que 15 anos formada por africanos falantes de línguas bantos.

As crianças representavam, em média, dois em cada três cativos. Nos plantéis que não eram renovados constantemente, podiam chegar a um terço ou até quase metade do total. Os autores mostram que não existia propriamente um mercado de crianças cativas, mesmo que algumas fossem compradas e vendidas, ou ainda doadas ao nascer, observam que estas operaçôes não assumiam qualquer função estrutural para o sistema escravista. Os principais traços demográficos do universo infantil estariam relacionados à fecundidade das cativas e à mortalidade infantil (FLORENTINO; GÓES, 2005, p. 211).

Os autores ressaltam que as crianças, ao escaparem "da morte prematura iam, aparentemente, perdendo os pais". Antes de um ano de idade, uma em cada dez crianças já não possuía pai e mãe anotados nos inventários. Aos cinco anos, metade parecia ser completamente órfā, e aos onze, o número aumentava para oito em cada dez. Mas náo somente a perda 
dos pais caracterizaria este quadro, como também a doação de crianças a filhos e parentes no batismo, embora não significassem necessariamente o definitivo rompimento da convivência entre pais e filhos, também figurava entre os motivos para que as crianças ficassem sem os pais, mas esta face da história não se pôde apreender pelos inventários. Outro motivo poderia ser a alforria de cativos sem que isso implicasse na alforria dos filhos.

No lado contrário dessa face da infância escrava, encontram-se dados sobre pequenas propriedades nas quais a escravaria era formada apenas, ou majoritariamente, por crianças. Citam como exemplo o caso de Tomás Gonçalves da Silva, que possuía um plantel de 24 escravos, dos quais 16 eram crianças (FLORENTINO; GÓES, 2005, p. 214).

Entretanto, Florentino e Góes (2005) ressaltam que as crianças sobreviventes não ficavam sozinhas: o batismo era uma das formas de criação de rede de relaçóes sociais escravas, em especial do tipo parental, que protegeriam essas crianças. Segundo os autores, os laços de compadrio uniam principalmente escravizados, e era um costume entre eles no Rio de Janeiro, tanto nas áreas rurais quanto urbanas. Inclusive, como se pôde observar em Inhaúma, unia escravos e plantéis diferentes.

[...] em propriedade longe do mercado escravo há pelo menos vinte anos, onde não raro mais de $90 \%$ da escravaria possuía parentes, ele com certeza seria irmão, primo, sobrinho ou neto de alguém. Em qualquer circunstância, porém, teria a criança já uma "tia" ou um "tio", mesmo que não consanguíneos. Um padrinho (e, muito frequentemente, uma madrinha), com certeza, os pais já lhe haviam providenciado logo pelo nascimento. (FLORENTINO; GÓES, 2005, p. 215).

Mattoso (1988) encontrou testamentos em que madrinhas e padrinhos libertam seus afilhados e afilhadas, ou deixam-lhes herança em dinheiro, joias e também escravos. Sobre o apadrinhamento, observa Mattoso:

Nascido, o escravo nenê é batizado sem muita demora. A escolha do padrinho e da madrinha é o resultado de estratégias de promoção social bastante parecidas àquelas encontradas entre os livres e libertos, porque 
a responsabilidade dos padrinhos perante a criança alarga-se também à mãe desta, que se tornará comadre. O compadrio consolida e estende os indispensáveis laços de solidariedade que permitem aos escravos sobreviver no meio de uma sociedade hostil e, às vezes, se libertar. (MATTOSO, 1988, p.51-52).

Florentino e Góes (2005) asseguram que, mesmo não sendo fácil que a criança escrava ficasse "insuportavelmente só", pois os escravos adultos "inventavam meios de, com o material disponível, fincar vigas de uma vida comunitária e cooperativa”, não é possível avaliar em que medida "esse empenho cativo protegia as crianças, especialmente considerando que a aceleração do tráfico de africanos tornava mais efêmeras as normas e mais instável a vida da comunidade" (FLORENTINO; GÓES, 2005 , p. 217). Perguntam-se os autores, além dos limites de alcance das redes sociais e parentais, sobre os limites do suportável para a criança escrava. Considerando as indagaçóes insolúveis, alegam que: “Talvez nos movimentados cruzamentos das grandes metrópoles brasileiras de hoje se encontrem algumas respostas - eles estáo apinhados de crianças, quase sempre negras".

Lima e Venâncio (1991) apontam que o abandono de crianças pretas triplicou e o de pardas dobrou entre os anos de 1864 a 1881 . Tal prática é relacionada diretamente à promulgação da Lei do Ventre Livre em $1871 \mathrm{e}$ ao fato de que seria mais interessante e lucrativo para os senhores alugarem as mulheres escravizadas como amas de leite a esperar oito anos para receber a indenização pela entrega dos ingênuos, contando-se, inclusive, com o risco de poder aproveitar apenas metade das crianças para o trabalho, devido às altas taxas de mortalidade da época.

O caminho para a transformação da criança escrava num adulto escravo, embora relativamente curto, não era fácil. Florentino e Góes (2005, p.217) falam desse processo, comparando-o ao "tormento da cana de açúcar - batida, torcida, cortada em pedaços, arrastada, moída, espremida e fervida”. Era assim, asseveram os autores, que se criava uma criança escrava: "haviam de ser batidos, torcidos, arrastados, espremidos e fervidos". Por volta dos doze anos de idade este processo estava se concluindo. Nos inventários, os autores puderam perceber que nesta idade os meninos e meninas começavam a trazer a profissão no sobrenome: Chico roça, João pastor, Ana mucama. 
Alguns haviam começado muito cedo. O pequeno Gastão, por exemplo, aos quatros anos já desempenhava tarefas domésticas leves na fazenda de José de Araújo Rangel. Gastão nem bem se pusera de pé e já tinha um senhor. Manoel, aos oito anos, já pastoreava o gado da fazenda de Guaxindiba, pertencente à baronesa de Macaé. E de Rosa, escrava de Josefa Maria Viana, aos 11 anos de idade dizia-se ser costureira. Aos 14 anos, era-se um adulto completo. (FLORENTINO; GÓES, 2005, p. 217).

O aprendizado dos ofícios e tarefas se refletia no preço da criança escrava. Por volta dos quatro anos, com o alto índice de mortalidade, não era muito lucrativo vender crianças, porém, "ao iniciar-se no servir, lavar, passar, engomar, remendar roupas, reparar sapatos, trabalhar em madeira, pastorear e mesmo em tarefas próprias do eito, o preço crescia" (FLORENTINO; GÓES, 2005, p. 218). O valor de uma criança de quatro anos poderia dobrar aos onze anos. Tal fato também foi comentado por Debret na descrição da prancha Uma senhora brasileira em seu lar:

Avança do mesmo lado um moleque, com um enorme copo de água. [...] Os dois negrinhos, apenas em idade de engatinhar e que gozam, no quarto da dona da casa, dos privilégios do pequeno macaco, experimentam suas forças na esteira da criada. Esta pequena população nascente, fruto da escravidão, torna-se ao nascer um objeto de especulação lucrativa para o proprietário e é considerado no inventário um imóvel ${ }^{4}$. (DEBRET, 1989, p. 53).

Os autores afirmam ainda que o "adestramento" também se fazia pelo suplício. Mas este náo era o do espetáculo, reservado aos adultos, mas "o suplício do dia-a-dia, feito de pequenas humilhações e grandes agravos". Lembrando que o suplício se dava inclusive pelas brincadeiras, aponta-se que "o quadro não pintado por Debret, mas descrito por Machado de Assis na literatura, não é difícil de ser imaginado": "a criança negra arqueada pelo peso de um pequeno escravocrata”. Afirma-se, ainda, que a vida das crianças escravas muito próximas à família do senhor era muito difícil: "O nhonhô, afinal, matriculado na mesma escola da escravidão, estava

4. Na realidade, escravo era um bem semovente, a quem a lei se referia como "coisa animada". 
a aprender sobre a utilidade de bofetadas e humilhaçôes" (FLORENTINO; GÓES, 2005, p. 219).

A literatura ficcional do século XIX nos oferece alguns exemplos do exposto acima sobre os suplícios da vida cotidiana enfrentados pelas crianças negras próximas dos senhores: “[...] o encargo da mucama era ainda mais pesado: ela tinha como dever comer o mais depressa possível os confeitos e amêndoas, para esvaziar as caixinhas, que Adélia destinava às roupas das bonecas" (ALENCAR, 1871, p. 32). ${ }^{5}$

Porém, as que estavam mais afastadas do contato senhorial, náo encontrariam destino muito diferente, ainda que as fontes sobre elas sejam mais lacônicas, náo parece difícil imaginar o quanto aprendiam pelo tratamento dispensado a seus pais se ainda tivessem a eles ou a seus parentes. Também encontramos exemplos desta forma de suplício na literatura ficcional da época:

Estendida por terra, com os pés no tronco, cabeça raspada e mãos amarradas para trás, permanecia Domingas, completamente nua e com as partes genitais queimadas a ferro em brasa. Ao lado o filhinho de três anos, gritava como um possesso, tentando abraçá-la, e, de cada vez que ele se aproximava da mãe, dois negros, à ordem de Quitéria, desviavam o relho das costas da escrava para dardejá-lo contra a criança. (AZEVEDO, 1994, p. 43) .

Por fim, os autores salientam dois aspectos: o primeiro diz respeito ao fato de a infância escravizada ser marca crucial do escravo crioulo; o segundo que a criança escrava era cria da escravidão, mas também era filha dos escravos. Sobre o primeiro, observam que o fato de ter nascido no Brasil oferecia aos crioulos adultos um "lugar privilegiado na hierarquia que organizava a vida da escravaria”, mas ao mesmo tempo os tornava mais "impacientes" em relaçáo à condição de escravos, os quais seriam, segundo os autores, os efeitos mais visíveis de uma infância escrava. Sobre o segundo, enfatizando que este seja mais difícil de conhecer, ressalvam que os escravos fizeram do catolicismo o mesmo que faziam com a cana e foram nisto eficientes, ou seja, em "bater, torcer, cortar em pedaços, arrastar,

5. A obra publicada em $1871 \mathrm{faz}$ parte da série de romances regionalistas do autor publicadas no Brasil durante o período literário denominado Romantismo. ( $O$ tronco do ipê, disponível em: www.brasiliana.usp.br, acesso em agosto de 2011).

6. A obra de 1881 marca o início do período literário denominado Naturalismo no Brasil. 
moer, espremer e ferver o catolicismo, de modo a reinventar o mundo da maneira possível”.

Dito de outra maneira, uma das formas de reinventar a própria vida dentro do sistema escravista e de poder criar laços parentais seria por meio do catolicismo, e as crianças seriam desde muito cedo iniciadas nessas práticas religiosas católicas, reinventadas do ponto de vista de negras e negros. Debret ainda ressalta a importância de negros livres idosos, falantes de diversas línguas africanas, para "acelerar os progressos dos novos catecúmenos" (DEBRET, 2001, p. 24).

Em seu estudo sobre a vida dos escravos no Rio de Janeiro oitocentista, Karasch (2000, p.193) aponta a existência de uma cultura afro-carioca "forjada a partir das muitas tradiçóes culturais da primeira metade do século XIX" que continua, conforme a autora, "a dar forma ao Rio contemporâneo".

Dentre os aspectos culturais que a autora procura ressaltar, está a questão dos usos da língua. A conservação da língua de origem era um dos aspectos mais importantes da vida dos escravizados longe de seus donos, e a cidade do Rio, antes de 1850, era um rico "museu" de línguas faladas em toda a África. Dos vários aspectos do uso da língua abordados, podemos destacar: como seria de interesse dos africanos aprender português porque isto lhes facilitaria a fuga; os modos como misturavam o português com suas próprias línguas criando falares outros; e que havia um número surpreendente de escravos e libertos alfabetizados.

Porém, havia um esforço muito grande dos donos de novos escravos africanos para que os mesmos falassem rapidamente, e somente, o português.

Mediante ameaças e violência física, transformavam os escravos boçais em criados falantes de português - pelo menos superficialmente. Porém, um motivo para a aparente "facilidade" com que muitos africanos aprendiam o português era porque ainda eram crianças e adolescentes quando chegavam à cidade. Os menores, de cinco ou seis anos, dominavam a língua com maior facilidade; os anúncios de jornais que fornecem a idade e informação de língua revelam quão fluentes os jovens africanos ficavam depois de um breve período de tempo. Por exemplo, o fugitivo Simão Ganguela, com cerca de dez anos de idade, era capaz de falar português muito bem depois de apenas sete ou oito meses vivendo com seu senhor. (KARASCH, 2000, p. 293-294). 
Destacamos aqui os usos da língua pois a autora salienta que as crianças entre seis e dez anos tinham papel fundamental na socialização dos adultos. Os escravizados recém chegados eram ensinados pelas crianças que sabiam português e outras línguas africanas.

Outra questão sobre as crianças apontada por Karasch (2000) é sobre a escolarização. A autora mostra um censo do Rio de Janeiro de 1884, o qual registra a presença de 152 menores pardos livres e oito negros livres nas escolas, embora não identifique o nível educacional. Traz ainda algumas curiosidades:

\footnotetext{
Em 1810, o capitáo de um navio negreiro relatou que um de seus passageiros não era escravo, mas o filho pequeno (cerca de sete anos de idade) de um dignitário de Cabinda que confiara o menino ao capitão para que o levasse para o Rio de Janeiro a fim de ser educado. Na mesma época, d. João VI ordenou que cada uma das colônias africanas mandasse dois meninos ao Rio para serem treinados em prática cirúrgica, de tal forma que pudessem retornar à África e cuidar de seu povo. Em consequência, Gonçalves dos Santos relatou que quatro deles tinham chegado ao Rio - dois de Angola, um de São Tome e um da ilha do Príncipe. Deveriam receber seu treinamento no Hospital Militar Real, à custa da Coroa. Pelo menos uma menina, Maria Constantina, de Angola, estava sendo educada no Rio em 1844. (KARASCH, 2000, p. 296-297).
}

A presença de crianças na escola era muito pequena e não é provável que o maior meio de alfabetização dos negros fosse a escola formal. Karasch apresenta algumas hipóteses, dentre elas, a de que os escravizados negros, crianças e adultos, podiam aprender por acompanharem seus donos nas aulas, fossem elas na escola ou particulares. Em outros casos, os senhores, conforme seus interesses econômicos, poderiam providenciar esse aprendizado. Conforme a função que os escravos devessem exercer, era interessante que pudessem ler e escrever. O comércio urbano necessitava das habilidades de leitura e escrita e também de conhecimentos de matemática.

Wissenbach (2002) busca considerar a existência de escravos alfabetizados e averiguar os usos e sentidos da escrita entre eles. Apoiada em Demartini (2001), a autora faz alusão aos processos voluntários de aprendizado da leitura entre crianças de diferentes estratos sociais, observando que muitas delas haviam sido introduzidas ao mundo da leitura por suas 
babás, geralmente ex-escravas, ou ainda por filhos de escravos, companheiros das crianças brancas em seus jogos infantis.

A escravidão produzia uma ruptura radical, mas nem por isso absoluta, nas culturas dos escravizados de primeira geração. Pelo registro de alguns viajantes, pode-se conhecer o fato de que as crianças eram "educadas", ou ao menos apreendiam as regras básicas de uma existência limitada pela origem, num ambiente bilíngue, conforme se pode ver em Karasch (2000). Normalmente, elas eram inseridas nas práticas da língua imposta pelo mundo hegemônico dos senhores enquanto acessavam o linguajar falado nas senzalas, nos becos, nos mercados, nas bicas, nos lavadouros e nas zonas portuárias. Essa linguagem do cotidiano não era outra senão a expressa em línguas Quimbundo, Jeje, Iorubá ou qualquer outra do tronco linguístico Níger-Congo ou, mais especificamente, do subgrupo Banto.

Alguns trabalhos como os de Robert Slenes, por exemplo, vêm demonstrando o compartilhamento do quadro linguístico, o que certamente possibilitava aos mesmos o estabelecimento de novos laços culturais entre si na situação de cativeiro. Certamente esses laços facultavam aos escravos intensas comunicaçôes nas senzalas que escapavam ao controle senhorial, abrindo caminho e criando canais extremamente propícios à elaboraçáo de estratégias de resistência contra a instituição, conforme observou Marquese (2004, p. 294-295).

As afirmaçóes acima reverberam uma das funçóes importantes para aqueles que estudam a criança e a infância: a função mediadora que a criança desempenha nas relaçóes sociais, fazendo-a protagonista nesse espaço uma vez que ocupa a função de colmatar relaçóes. Ao transitar entre a senzala e a casa grande, entre a casa e a rua, ou até entre as línguas, preenchia espaços não só linguísticos, mas também socioculturais. Demartini (2001) chega a considerar a possibilidade das crianças brancas serem introduzidas nas práticas de leitura pelos negros e seus filhos no final do século XIX, e que:

[...] a vontade de aprender a ler da criança branca estivesse ligada às relaçóes de amizade com crianças negras e o papel de alfabetizadores que muitos negros desempenharam em várias famílias, sem que lhes tivessem sido reconhecida esta função. (DEMARTINI, 2001, p. 138). 


\section{Buscando um sentimento de infância negra}

Entretanto, um exemplo de outras imagens são os retratos de crianças negras produzidos pelo fotógrafo Augusto Militão de Azevedo. Neles podemos ver crianças bem vestidas e penteadas, portando joias e acessórios, posando para cenas em cenários montados em estúdio. Nestes retratos a ênfase está nas pessoas, não em suas funçóes, como ocorre em outros conjuntos de fotografias do século XIX. Isto demonstra que se trata de pessoas com algum poder aquisitivo, que podiam atender a alguns padróes sociais como recorrer ao suporte moderno para fixar uma memória de si e de seus descendentes.

Chamo as imagens de construçóes narrativas como representação gráfica, que, como a literatura, não são literais, todavia como conjunto constroem uma linguagem visual sobre a figura dos negros e das crianças, tanto das que são recorrentes quanto das que não são vistas. Lima (2007, p.133) aponta que as cenas pintadas por Debret "são, na realidade, imagens literárias que muito devem à sua formação artística, responsável por sua habilidade em observar, registrar e compor".

Fotografias e gravuras não são vistas aqui como imagens homogêneas e nem do mesmo tipo, pois usam suportes técnicos e têm possibilidades de reprodução muito diferentes ${ }^{7}$. Porém, alguns aspectos da fotografia, como dados de comunicação do real que a pintura e a gravura não teriam, podem aqui ser unidos pela preocupação de Debret com a "elaboração de um discurso histórico sobre o Brasil e com a fidelidade de seu testemunho/ relato para com a verdade dos fatos que apresenta", conforme assevera Lima (2007, p.128).

Observa-se que fotografia também é uma representação - passa por escolhas e processos que decidem o resultado. Houve preocupação com estes aspectos e a abordagem aconteceu a partir de aspectos de continuidade e descontinuidade das imagens: foco no mundo dos adultos, espaço do "entre", universo aristocrático, imponência das posses dos senhores de escravos e demonstração de poder. Uma coisa eram as imagens dos

7. No caso das gravuras de Debret, por exemplo, a litográfica, meio de reprodução, ocasionava várias alteraçôes na imagem quando de sua impressão. "Geralmente, o que ocorria durante esse processo era a definição de outra imagem, muitas vezes fruto da interferência do próprio artista, mas também do trabalho de artífices que se habilitavam para tal. $O$ trabalho de transferência da imagem, fosse ela desenho ou aquarela, para a litogravura implicava opçóes estéticas que eram, de certa forma, determinadas pela intenção da publicação" (LIMA, 2007, p. 147). 
fazendeiros, das classes abastadas, ricos fotografando seus escravos, outra coisa as fotografias dos escravizados, livres e libertos. Procurei dialogar com as marcas de uma interpretação pela passividade, de que os fotografados eram passivos, desvinculando-me dessa perspectiva, a partir do levantamento daquilo que as imagens davam a ver.

No caso da leitura das imagens de Debret, a mesma esteve diretamente ancorada na bibliografia, seja sobre escravidão, seja sobre história da criança e da infância. Junte-se a isso o fato de as pranchas de Debret também conterem descrições das cenas representadas, o que de certa forma confere a elas um caráter de verdade. $\mathrm{O}$ texto escrito serve como ancoragem para imprimir às imagens um efeito de realidade ou de referente. Talvez, neste caso, discurso-imagem e discurso-escrito sirvam de argumento de autoridade um ao outro, validando-se mutuamente, de forma que o sentido produzido por ambos seja o de cópia do real.

De modo geral, estas imagens também confirmam alguns estudos europeus sobre iconografia da idade média e dos séculos XVII a XIX com crianças, como o de Ariès (1981) ou o de Chalmel (2004). Nestes trabalhos, muito se ressaltou das imagens de crianças muito próximas ou parecidas com adultos, no caso de retratos pintados. Aqui, a proximidade se dá especialmente pelo vestuário. Mesmo considerando que adultos e crianças estejam posando em seus melhores trajes, os modos com que se vestem acabam por proporcionar uma espécie de indiferenciação etária, marcada apenas pela diferença de tamanho. Isto vale também para as representaçóes da escravidão, nas quais as quitandeiras e pequenos vendedores, igualados pelo trabalho, diferenciam-se pela estatura.

$\mathrm{O}$ cuidado com as crianças, em especial as recém-nascidas, bem como com suas mães foi alvo de discursos e práticas do sistema escravista, conforme observado a partir de Marquese (2004), no trabalho com os manuais dos agricultores. Apesar disso, é fato que nem todas as mães podiam estar perto dos filhos ou levá-los consigo. Pardal (2005) descreve uma invenção de um fazendeiro do Maranhão que obrigava as escravizadas a deixarem seus filhos, crianças ainda em fase de amamentação, no tejupado - buraco cavado na terra, onde a criança era colocada até a metade do corpo (PARDAL, 2005, p.53).

Caso consideremos a presença de brinquedos ou do brincar como um sinal de infância, esta será uma imagem quase não vista em relação 
às crianças negras no século XIX, sendo que nos retratos essa ausência é ainda maior.

Embora continue observando que além do tamanho, crianças e adultos também se difirem ou se igualam nos tipos de tarefas que realizam e que, ainda que náo tenham idade para realizar trabalhos, as crianças pequenas estejam às costas de suas mães para que estas tenham as mãos livres para os afazeres, passamos a aventar outras leituras desses sinais de infância negra.

Consideramos que essa seja uma prática cultural africana (e indígena), mesmo dentro da escravidão, o que revela uma preocupação específica com a criança pequena sendo, portanto, reveladora de uma especificidade e uma particularidade de sentimento de infância negra. Quando não estão no colo, muitas crianças fazem parte das cenas reproduzidas, tanto por Debret quanto por muitos fotógrafos do século XIX. São imagens de crianças com adultos que trabalham e que também revelam um modo de estar com as crianças, um modo específico de cuidar as crianças, ao mesmo tempo em que se cumprem os afazeres.

Essa forma de cuidar não aparta a criança da rotina dos adultos, pelo contrário, trazer a criança para o seu cotidiano cria a possibilidade de interagir com ela e resguardá-la. Cria uma comunidade em torno dela para que não se perca ou se machuque, ao mesmo tempo em que é educada. Perto da máe ou de outros adultos, ela aprende formas de resistir, de falar, de cantar, de calar, de trabalhar e de sobreviver. Uma roda de jongo, na qual crianças, adultos e jovens podem participar, também pode revelar resquícios dessa prática.

Náo perdendo de vista que se trata de um contexto de práticas escravistas, é possível pensar como mulheres e homens escravizados, mas sobretudo mulheres, conseguiram imprimir um jeito africano de cuidar de suas crianças, criando comunidades em torno delas. Por exemplo, Somé (2007), pertencente ao povo Dagara, de Burkina Faso, relata que:

Quando você tem um filho, por exemplo, não é só seu, é filho da comunidade. Do nascimento em diante, a mãe não é a única responsável pela criança. Qualquer outra pessoa pode alimentar e cuidar da criança. Se outra mulher tiver um bebê, ela pode dar de mamar a qualquer criança. Não há o menor problema. (SOMÉ, 2007, p. 42). 
Clavert (2009), ao apresentar a descrição do rito Iromb, uma celebração de iniciação e passagem da adolescência, presente na cultura wongo, da República Democrática do Congo, nos remete aos sentidos de uma educação tradicional negro-africana, a qual pressupóe a participação da criança nas atividades e celebraçóes dos adultos:

\begin{abstract}
Durante a sua primeira infância, mesmo quando não participa diretamente dos deveres e direitos dos adultos, é considerada uma pessoa e tratada como tal. Pouco a pouco vai ampliando sua rede de relacionamentos e sua compreensão do entorno. Sua primeira escola é a casa e a vizinhança, e seus primeiros formadores sáo todos aqueles que com ela convivem. Com eles aprende a andar, falar e a relacionar-se com os outros e com a natureza. É educada por aqueles que a cercam diretamente: por suas palavras, seus gestos, seus olhares, em suma, pelo modo peculiar que essas pessoas têm de ser e de viver. (CLAVERT, 2009, p. 16).
\end{abstract}

Ao descrever as práticas educacionais não formais do contexto africano, Clavert (2009) aponta alguns aspectos importantes para a compreensão das imagens de crianças próximas ou integrando as cenas de trabalho dos adultos. Com base em estudos de alguns africanistas, o autor considera que uma educação tradicional negro-africana seja integradora, coletiva, pragmática, funcional, progressiva e polivalente, atendendo as dimensões do sagrado.

Os aspectos que ressaltamos com as duas últimas citaçóes acima, mostrando dois povos diferentes, mas com concepções parecidas, ressaltam que por ser integradora e coletiva, uma visão negro-africana de infância visa a "integração e aceitação da criança no grupo e a leva a participar ativamente da vida e das atividades" (CLAVERT, 2009, p. 71) e coloca a criança sob o cuidado de todas as pessoas pertencentes à comunidade, sendo que a "tarefa de educar concerne a todos, mesmo havendo situaçóes em que essa responsabilidade se torne exclusiva dos pais, dos mais velhos ou de pessoas qualificadas" (CLAVERT, 2009, p. 71-72).

Sabemos ser arriscado fazer uma relação direta entre as práticas ainda existentes na África, e nas diásporas africanas, e o que foi visto nas imagens. Todavia, talvez estas imagens, fugindo um pouco das intencionalidades primeiras de seus discursos, tenham perpetuado um sentimento de infância 
negra, já que, como Ariès cria um conceito para dar conta do aparecimento de uma nova relação com as crianças na Europa, destacando-se crianças brancas e nobres, há de se verificar se este conceito pode vir a ser utilizado para descrever a maneira singular pela qual as mães negras cuidam de seus filhos, a partir de concepçóes distintas da europeia.

Com base em relatos de viajantes, identificamos o hábito de trazer crianças amarradas às costas, um traço cultural existente na África antes da colonização do Brasil, que aqui foi largamente empreendido por mulheres negras e mestiças que circulavam no meio urbano, como escravas de ganho ou como ambulantes libertas. Os viajantes perceberam a importância dessas mulheres na vida social citadina e elas foram perpetuadas nessas imagens. Além de Debret, Rugendas foi um dos que registrou esse costume em diferentes imagens. Em uma delas, nove mulheres ocupam o centro da cena, três delas carregando crianças nas costas.

Quando nos deparamos com gravuras realizadas na África no século XIX, somos instigados a estabelecer laços de continuidade em vários aspectos das habilidades africanas transferidas ao mundo diaspórico. Tratando-se de um cuidado muito específico dedicado às crianças pequenas, supomos que tal tratamento despendido à primeira infância seja um traço de unidade no contexto africano, cuja temporalidade é de difícil precisão, mas que, no Brasil, se disseminou trazido por mulheres africanas.

Portanto, esses procedimentos, apreendidos num conjunto de experiências e vivências sociais sistematizadas e transmitidas como repertório, são parte de um patrimônio coletivo de saberes.

Slenes (1988) aponta para mudanças nas pesquisas sobre famílias escravas surgidas a partir de 1980 e que revelariam, entre outras coisas, que as unióes estáveis e duradouras entre escravizados eram mais comuns do que se imagina, pelo menos em São Paulo, província com os mais altos índices de casamento registrados pela igreja. Resulta disso o fato de que muitas crianças não só conheciam, mas também conviviam, eram criadas e educadas pela mãe e pelo pai, ou pelo menos por um deles, ou próximo de um deles ${ }^{8}$.

Apesar da dureza da escravidão, é possível pensar numa singularidade da infância negra, marcada pela reverberação dos modos negro-africanos

8. Slenes (1988, p.193) relativiza e assume que as novas pesquisas não visam romantizar a vida no cativeiro. Em plantéis menores, por exemplo, essa possibilidade era bastante diminuída, e mesmo em plantéis maiores a separaçáo de famílias sempre existia como ameaça. 
de conceber a infância e sua educação; pensar em crianças sendo cuidadas e educadas, tanto por seus pais, quanto por uma comunidade inteira que se formava em volta dela, inclusive pelos padrinhos e madrinhas, cujos vínculos, conforme Mattoso (1988, p.51-52), consolidam e estendem "indispensáveis laços de solidariedade que permitem aos escravos sobreviver no meio de uma sociedade hostil e, às vezes, se libertar".

Pensando no aspecto da movimentaçáo que o trabalho de algumas crianças proporcionava como o de mensageiros, acompanhantes, auxiliares no transporte dos tabuleiros, tripés, trouxas de roupas ou outros utensílios, ponderando que esse espaço entre realizar pequenos ou leves trabalhos e o de ser aprendiz, nessa idade entre seis e doze anos, quando sua força de trabalho será explorada ao máximo, é possível entrever uma "infânciamoleque", que é mediadora, brincante e desafiadora, mesmo que seja "encolhida", conforme salientou Mattoso (1988). Teriam então algum "gostinho na vida", colhido entre as tarefas, satisfação miúda entre alguns brinquedos, brincadeiras, travessuras e transgressóes.

Para finalizar, retomemos a epígrafe: "se fosse sobre criança de rua, ia ser tudo negra”, e a comparemos com a citação abaixo para pensar como o estudo da infância a partir das imagens do século XIX pode nos ajudar a repensar a representaçáo das crianças negras hoje.

O grande clichê é o menor adotado ou abandonado, mas também tivemos o moleque de recados engraçado ou o jovem rapper. De uma maneira geral, o que mais quero destacar é que as crianças negras não têm família. É uma visão preconceituosa porque tende a incorporá-las de forma solitária em um elenco de brancos e muitas vezes fazendo o papel do mais inculto ou ignorante. Portanto, a criança negra é incorporada da mesma forma que qualquer personagem negro: entra como estereótipo de si mesmo, e nunca como representação de qualquer ser humano, do brasileiro comum. Esse privilégio somente é dado aos brancos. (ARAÚJO, 2007).

Como tanto tempo depois da produção das imagens de Debret e Militão, nossos meios de comunicação com seus filmes, novelas, séries, bem como nossos materiais didáticos e outros que permeiam nosso cotidiano ainda teimam em construir discursos imagéticos que coloquem as crianças negras em condição de inferioridade? Por que as imagens de 
Debret são mais reproduzidas que os retratos de Militão e outras imagens parecidas? Quais são as consequências disso para a autorrepresentação das crianças? O que nós educadoras e educadores podemos fazer para criar outros textos imagéticos em nossa prática escolar?

\section{REFERÊNCIAS}

ARAÚJO, J. Z. A criança negra na televisáo brasileira. Rio de Janeiro: 30/05/2007. Disponível em <http://portalmultirio.rio.rj.gov.br/portal/riomidia/> acesso em outubro de 2010 .

ARIÈS, Philippe. História social da criança e da família. 2.ed. Rio de Janeiro: LTC, 1981. AZEVEDO, A. O Mulato. 12.ed. São Paulo: Ática, 1994. Texto integral. Cotejado com a 3.ed., Rio de Janeiro: B.L. Garnier Livreiro-Editor, 1889.

BURKE, P. Testemunha ocular: história e imagem. Trad. Vera Maria Xavier dos Santos. Bauru: EDUSC, 2004.

CHALMEL, L. Imagens de crianças e crianças nas imagens: representaçóes da infância na iconografia pedagógica nos séculos XVII e XVIII. Educaçáo e Sociedade. Campinas, v.25, n.86, p. $57-74$, abr./ 2004.

CLAVERT, M. S. Da densa floresta onde menino entrei, homem saí. Rito Iromb na formação do indivíduo Wongo. 2009. Dissertação (Mestrado em Psicologia). Instituto de Psicologia. Universidade de São Paulo, São Paulo, 2009.

DEBRET, J. B. Viagem pictoresca e histórica ao Brasil. Belo Horizonte: Itatiaia/São Paulo: EDUSP, 1989.

DEBRET, J. B. (ilustraçôes e comentários); STRAUMANN, Patrik (Org.). Rio de Janeiro, cidade mestiça. São Paulo: Companhia das Letras, 2001. Rosa Freire d'Aguiar (trad.).

DEMARTINI, Z. B. F. Crianças como agentes do processo de alfabetização no final do século XIX e início do XX. In: MONARCHA, C. (Org.). Educaçáo da infância brasileira: 18751983. Campinas, Autores Associados, p. 121-156, 2001.

FLORENTINO, M.; GÓES, J. R. Morfologias da infância escrava: Rio de Janeiro, séculos XVIII e XIX. In: FLORENTINO, M. (Org.). Tráfico, cativeiro e liberdade. Rio de Janeiro, séculos XVII-XIX. Rio de Janeiro: Civilização Brasileira, 2005.

FONSECA, M. V. A educaçáo dos negros: uma nova face do processo de abolição da escravidão no Brasil. Bragança Paulista (SP): EDUSF, 2002.

GOUVÊA, M. C. A literatura como fonte para a história da infância: possibilidades e limites. In: FERNANDES, R., FARIA FILHO, L. M., LOPES, A. (Orgs.). Para a compreensáo histórica da infância, v.1. Porto: Campo das Letras, p.21-43, 2006. 
JOVINO, I. S. Crianças negras nas imagens do século XIX. Tese (Doutorado em Educação). Programa de Pós-graduação em Educação. Universidade Federal de São Carlos, São Carlos, 2010. KARASCH, M. C. A vida dos escravos no Rio de Janeiro (1808 - 1850). Trad. Pedro Maia Soares. São Paulo: Companhia das Letras, 2000.

KOSSOY, B.; CARNEIRO, M. L. T. O olhar europeu. O negro na fotografia brasileira do século XIX. São Paulo: Edusp, 2002.

LIMA, L. L. G.; VENANCIO, R. P. O abandono de crianças negras no Rio de Janeiro. In: PRIORE, M. D. (Org.). História das crianças no Brasil. São Paulo: Contexto, p. 61-75, 1991. LIMA, V. A. E. Voyage pittoresque et historique au Brèsil. Consideraçóes sobre uma obra. In: J. B. Debret, historiador e pintor: a viagem pitoresca e histórica ao Brasil (18161839). Campinas: Editora da Unicamp, 2007.

MARQUESE, R. B. Feitores do corpo, missionários da mente: senhores letrados e o controle dos escravos nas Américas, 1660-1860. São Paulo: Companhia das Letras, 2004.

MATTOSO, K. Q. O filho da escrava. Em torno da Lei do Ventre Livre. Revista Brasileira de História. São Paulo. v. 8, n.16, p.37-55, mar./ago. 1988.

MEILASSOUX, C. Antropologia da escravidáo: o ventre de ferro e dinheiro. Rio de Janeiro: Jorge Zahar, 1995.

MOTT, M. L. B. A criança escrava na literatura de viagens. Cadernos de Pesquisa. São Paulo: Fundação Carlos Chagas, n.31, p.98-57, dez. 1979.

MÜlleR, M. L. R. A cor da escola: imagens da Primeira República. Cuiabá: Entrelinhas/ EdUFMT, 2008.

PARDAL, M. V. O cuidado às crianças pequenas no Brasil escravista. In: PINTO, M. A infância como construção social. In: SARMENTO, M. J.; PINTO, M. (Orgs.). As crianças: contextos e identidades. Minho (Portugal): Universidade do Minho/ Centro de Estudos da Criança, p. 33-73, 1997.

PRIORE, M. D. (Org.). História das crianças no Brasil. São Paulo: Contexto, 1991.

ROBERT, S. Lares negros, olhares brancos: histórias da família escrava no século XIX. Revista Brasileira de História. São Paulo. v.8, n.16, p.189-203 mar./agosto 1988.

ROMÃO, Geruse. O educador, a educação e a construção de uma auto-estima positiva no educando negro. In: Racismo e anti-racismo na educaçáo: repensando nossa escola. Cavalleiro, E. (Org). São Paulo: Summus, 2001. P. 161-178

SANTOS, G. A. A invençáo do "ser negro": um percurso das idéias que naturalizaram a inferioridade dos negros. São Paulo: Educ/FAPESP; Rio de Janeiro: Pallas, 2002. 
SARMENTO, M. J.; PINTO, M. As crianças e a infância: definindo conceitos, delimitando o campo. In: (Orgs.). As crianças: contextos e identidades. Minho (Portugal): Universidade do Minho/ Centro de Estudos da Criança, p. 9-30, 1997.

SCHWARTZ, S. B. Historiografia recente da escravidão brasileira. In: Escravos, roceiros e rebeldes. Trad. Jussara Simões. Bauru (SP): EDUSC, p. 21-82, 2001.

SILVEIRA, O. Vinte de novembro: história e conteúdo. In: SILVA, P. B. G.; SILVÉRIO, V. R. (Orgs.). Educaçáo e açóes afirmativas: entre a injustiça simbólica e a injustiça econômica. Brasília: Instituto Nacional de Estudos e Pesquisas Educacionais Anísio Teixeira, p.21-42, 2003.

SLENES, R. W. A. Lares negros, olhares brancos: histórias da família escrava no século XIX. Revista Brasileira de História. São Paulo. v.8, n.16, p.189-203 mar./agosto 1988.

SOMÉ, S. O espírito da intimidade: ensinamentos ancestrais africanos sobre maneiras de se relacionar. Trad. Deborah Weinberg. São Paulo: Odysseus Editora, 2007.

VASCONCELOS, Vera M. Ramos de (org). Educação da infância: história e política. Rio de Janeiro: DP\&A, 2005. p.51-72

WALSH, R. Notícias do Brasil (1828-1829), v. I e II. Belo Horizonte: Itatiaia, São Paulo: Edusp, 1985.

WISSENBACH, M. C. C. Cartas, procuraçóes, escapulários e patuás: os múltiplos significados da escrita entre escravos e forros na sociedade oitocentista brasileira. Revista Brasileira de História da Educaçáo. Campinas, n. 4, p.103-122, Jul./dez. 2002. 


\section{PARTE 2}

\section{RELAÇÕES DE GÊNERO}




\section{RELAÇÕES DE GÊNERO: ALGUMAS CONSIDERAÇÕES CONCEITUAIS}

Tereza Lopes Miranda

Edina Schimanski

Universidade Estadual de Ponta Grossa

\section{INTRODUÇÃO}

O presente capítulo tem como objeto de estudo as questôes relacionadas a gênero e suas contradiçóes no contexto social a partir das relaçóes estabelecidas entre homens e mulheres na sociedade. $\mathrm{O}$ texto centra-se na conceituação de gênero, buscando uma interlocução direta com o debate atual que cerca a temática. Compreende-se, portanto, que falar em gênero implica a priori discorrer sobre uma identidade de gênero, a qual diz respeito à percepção subjetiva de ser masculino ou feminino, conforme os atributos, comportamentos e papéis convencionalmente estabelecidos para homens e mulheres no contexto social.

Evidencia-se aqui uma compreensão de gênero que é problematizada e complexa por excelência na sua totalidade conceitual e histórica, a qual leva em consideração processos sociais articulados a partir de relações que se organizam social, política, cultural e economicamente em um determinado tempo e espaço. Nessa seara, as categorias feminismo, sexualidade e trabalho, entre outras, emergem como elementos essenciais para a compreensão e construção das relaçóes sociais de gênero na atualidade.

Gênero: tecendo algumas considerações conceituais

Em termos sociais e culturais, a unidade lexical "gênero", na sua acepção pragmática, vem sendo usada desde a década de 1970 para nortear questóes que se referem às diferenças sexuais. 
Do latim genus, o termo gênero significa raça, extração, família. Contudo, ele foi inicialmente usado pelas feministas americanas no intuito de mostrar o caráter social das distinçóes baseadas no sexo. O termo proposto era defendido por historiadoras que afirmavam que a pesquisa sobre as mulheres transformaria os paradigmas científicos, o que, além de propor novos temas, imporia uma reavaliação crítica aos critérios do trabalho científico, implicando em um novo olhar sobre a história ou até em uma nova história. Essa nova história que incluiria as mulheres como sujeitos dependeria da maneira como o conceito de gênero se desenvolveria, enquanto categoria de análise, na qual a construção desse novo olhar seria fundamental na articulação do gênero com a classe e com a raça (SCOTT apud SAMARA, 1997).

O interesse por gênero, classe e raça, enquanto categoria de análise, demonstra o compromisso de pesquisadoras e pesquisadores com a inclusão da voz dos sujeitos excluídos, assinalando que as desigualdades de poder se estabelecem no mínimo a partir desses três eixos principais: gênero, classe e raça.

Portanto, gênero é um conceito que não pode ser compreendido se náo for articulado com a ideia de classe e com questóes de cunho étnico-racial. $\mathrm{O}$ conceito como tal se articula a diversos contextos e suas especificidades. $\mathrm{O}$ sujeito deve ser considerado como singular, mas envolto pela realidade sociocultural de seu tempo, em um espaço determinado que, contém em si, uma história própria, mas que também é coletiva, portanto não pode ser considerada de maneira isolada das demais questôes.

Para Matos (1997), gênero é uma categoria que procura destacar que os perfis masculinos e femininos se definem um em função do outro.

[...] perfis se constituem social, cultural e historicamente num tempo, espaço e cultura determinados. Não se deve esquecer, ainda, que as relaçóes de gênero são um elemento constitutivo das relaçôes sociais baseadas nas diferenças hierárquicas que distinguem os sexos e são, portanto, uma forma primária de relaçóes significantes de poder. Sendo uma de suas preocupaçôes evitarem as oposiçôes binárias fixas e naturalizadas, os estudos de gênero procuram mostrar que as referências culturais são sexualmente produzidas, por meio de símbolos, jogos de significação, cruzamentos de 
conceitos, relaçóes de poder, conceitos normativos e relaçóes de parentesco econômicas e políticas. (MATOS, 1997, p. 97- 98).

O olhar projetado sobre nós mesmos e sobre as diferenças que permeiam a sociedade é um olhar construído pela cultura e já estabelecido socialmente.

[...] para as ciências sociais e humanas, o conceito de gênero se refere à construçáo social do sexo anatômico [...] gênero significa que mulheres e homens são produtos da realidade social e náo decorrência da anatomia de seus corpos. (CARRARA; HEILBORN, 2009, p. 39).

Scott (1990) propõe que, no seu uso apenas descritivo, gênero é somente um conceito associado ao estudo de coisas relativas às mulheres, mas não dispóe de força de análise suficiente para propor mudanças nos paradigmas históricos postos. Para Scott (1990), gênero está relacionado às relaçóes de poder.

Não faz muito sentido ou não é eficiente provar que as mulheres têm uma história ou que contribuíram com as mudanças políticas principais da sociedade ocidental. Explicando melhor, as condições das mulheres não sofreram nenhuma alteração apenas por se saber que elas participaram ativamente da Revoluçáo Francesa, por exemplo. Este tipo de reaçáo encerra um desafio teórico, exigindo análise para além das relaçóes entre masculino e feminino no passado, mas também ligando a história do passado com as práticas históricas atuais (SCOTT apud SAMARA, 1997, p.66).

Analisar as questôes de gênero hoje, nos remete à busca de informaçóes na História, na Antropologia, na Sociologia e na Filosofia, entre outras disciplinas, para que possamos compreender como o processo das relaçôes entre os seres humanos vem sendo construído, desde as sociedades mais antigas até nossa época. Isso nos leva a compreender que a concepção de gênero passa por um domínio que tem caráter interdisciplinar. Nesse sentido, o conceito de gênero está envolto por diferentes significados e articulado a categorias sociais abrangentes, como, por exemplo, a desigualdade social.

Nas sociedades de classe, as diferenças são tratadas como desigualdades, dentre as quais apontamos as diferenças de gênero que tem 
sido um meio de opressão da mulher, negando sua condição humana de igualdade.

Se nos voltarmos para as sociedades de classes da antiguidade ocidental (Grécia e Roma) ou, oriental (China e Japão) ou, na Idade Média, para as sociedades da América pré-colombina (Incas e Astecas) ou para as sociedades de castas na Índia, nelas a vida social é dominada pelos homens. Possuir a terra da cidade, sacrificar aos deuses, defender suas terras de armas na mão, exercer as magistraturas e a soberania política, desenvolver a Filosofia, a Matemática entre outras questóes, eram privilégios masculinos na Atenas clássica. Para um grego, ser um homem plenamente é, antes de tudo, ser um homem e não uma mulher, ser livre e não escravo; ser ateniense e não estrangeiro. (GODELIER, 1980, p. 10-11).

Percebemos a situação da mulher como um ser de segunda categoria, colocada à margem da sociedade quando comparada ao homem. À medida que ela náo participa ativamente da vida em sociedade, sua história se define por aqueles que têm voz ativa e, portanto, constroem-na a partir de seus conceitos, que se solidificam na forma do que Bourdieu (2003) vai chamar de "forças simbólicas", que passam a se constituir como habitus no qual as instituiçôes como a família, a igreja, a escola e o estado prestam colaboração nessa reprodução. Assim, estamos entendendo que:

[...] força simbólica é uma forma de poder que se exerce sobre os corpos, diretamente, e como que por magia, sem qualquer coação física; mas essa magia só atua com o apoio de pré-disposiçóes colocadas, como molas propulsoras, na zona mais profunda dos corpos. (BOURDIEU, 2003, p.50).

O simbolismo expresso por Bourdieu (2003) é um fenômeno que embasa a educaçáo diferenciada na família, na escola e na sociedade para meninas e meninos. $\mathrm{Na}$ sociedade de classes, constroem-se cidadãs e cidadãos com papéis distintos, cuja determinação se inicia mesmo antes do nascimento. Sobre a base simbólica repousam as definiçóes de papéis de gênero que se acentuarão no comportamento dos sujeitos, se manifestando na escolha da profissão e na postura que apresentarão na sociedade, entre outras coisas. Aos homens é relegado o espaço, o poder e a liberdade, portanto o 
carro, o cargo, a política e o domínio público. Às mulheres a serenidade, o trato com as coisas da natureza, a solidariedade, o cuidado, o carinho, a delicadeza, a obediência, a maternidade vivenciada desde a infância ao brincar de boneca, o dever de servir e o limite do espaço privado. Nesse sentido, a herança filosófica tem definido por muitos séculos os espaços onde mulheres e homens devem estar, bem como a forma com que devem se comportar.

Gênero, enquanto categoria histórica e sociocultural, emerge justamente como conceito de análise para questionar esses espaços que definem os comportamentos de homens e mulheres baseados no sexo. Para Bourdieu (2003), as mulheres constituem elementos fundamentais na economia de bens simbólicos, onde as disposiçóes que ele chama de habitus, não se separam das estruturas que as produzem e reproduzem. Portanto, está internalizado nos nossos gestos mais inocentes e se manifesta "naturalmente", por isso, sem perceber estamos reforçando o chamado:

[...] princípio da inferioridade e da exclusão das mulheres, que o sistema mítico-ritual ratifica e amplia, a ponto de fazer dele o princípio de divisão de todo o universo, não é mais que a dissimetria fundamental, a do sujeito e do objeto, do agente e do instrumento, instaurada entre o homem e a mulher no terreno das trocas simbólicas, das relaçóes de produção e reprodução do capital simbólico, cujo dispositivo central é o mercado matrimonial, que está na base de toda a ordem social: as mulheres só podem aí ser vistas como objetos, ou melhor, como símbolos cujo sentido se constitui fora delas e cuja função é contribuir para a perpetuação ou o aumento do capital simbólico em poder dos homens. (BOURDIEU, 2003, p. 55).

A configuração do habitus está presente na educação familiar, na escola em todos os níveis, nos espaços de reprodução dos "valores" religiosos e no cotidiano das pessoas. Nesse sentido, vale dizer que a diferença é construída, porque, sendo comparada, está sempre posta em relação ao outro.

Virilidade, como se vê, é uma noção eminentemente relacional, construída diante dos outros homens para os outros homens e contra a feminilidade, por uma espécie de medo do feminino, e construída primeiramente dentro de si mesmo. (BOURDIEU, 2003, 67). 
Percebemos que a realidade, enquanto meio, no qual homens e mulheres estão imersos, é de fundamental importância na abordagem e construção do conhecimento, tanto quanto análise de cunho teórico, como forma propositiva de mudanças no processo do habitus culturalmente construído. As mulheres são tratadas como objetos ou símbolos, cujos sentidos não lhes pertencem e cuja função é manter o capital simbólico, circulando como mercadoria de pouco valor, embora os homens também sejam afetados, particularmente no que tange a manter a virilidade como uma resposta do corpo às exigências da violência simbólica exercida sobre eles.

O mundo social constrói o corpo como realidade sexuada e como depositário de princípios de visão e de divisão sexualizante. Este programa social de percepção incorporada aplica-se a todas as coisas do mundo e, antes de tudo, ao próprio corpo, realidade biológica: é ele que constrói a diferença entre os sexos biológicos conformando-a aos princípios de uma visão mítica do mundo, enraizada na relação arbitrária da relação de dominação dos homens sobre as mulheres, ela mesma inscrita, com a divisão do trabalho, na realidade da ordem social. (BOURDIEU, 2003, p 19-20).

A diferença anatômica dos sexos entre o macho e a fêmea, em especial a diferença entre os órgãos sexuais, são vistas como uma justificativa natural da diferença socialmente construída enquanto desigualdade entre gêneros, principalmente na divisão social do trabalho. Isso se dá ao fato de que as diferenças anatômicas se constroem pelo princípio de visão social. Essas diferenças socialmente construídas se tornam fundamento e naturalizam a visão social que as alicerça. Caímos, então, no que o Bourdieu (2003) chama de relação circular:

[...] que encerra o pensamento na evidência de relaçóes de dominação inscritas ao mesmo tempo na objetividade, sob forma de divisóes objetivas, e na subjetividade, sob forma de esquemas cognitivos que, organizados segundo essas divisões, organizam a percepçáo das divisóes objetivas. (BOURDIEU, 2003, p. 20).

Verifica-se que há uma relação recíproca entre as condiçôes objetivas e subjetivas no que concerne à forma como os comportamentos são 
exercidos. Sendo assim, a subjetividade dos sujeitos determina como seu comportamento se objetiva e este, por sua vez, é o motor da geração das subjetividades que fundamentam a prática dos sujeitos. Portanto, mudar tais circunstâncias não é um processo simples, mas uma condição que requer, além da compreensão e da construção desse processo, um esforço contínuo e politicamente comprometido com a mudança, também do ponto de vista simbólico.

Para Godelier (1980), a subordinação feminina é uma realidade social fundamentada em três dimensóes: econômica, política e simbólica. No plano econômico, basta olharmos para a divisão sexual do trabalho entre público e privado, no qual as mulheres não têm acesso às mesmas profissôes, muito menos aos mesmos salários. $\mathrm{Na}$ questão política, que envolve necessariamente o poder, as mulheres formam um contingente de mais de $50 \%$ da população, no entanto, possuem menos de $10 \%$ da representação política (GODELIER, 1980). No plano simbólico, vinculam-se imagens assimétricas entre os gêneros, onde perpassa a imagem do homem-sujeito em contraste com a mulher-objeto, sendo que "os estereótipos são ensinados na mais tenra idade e estruturam de antemão a percepção da realidade social” (GODELIER, 1980, p. 11-12), cultural e religiosa.

No que se refere à dimensão simbólica, conforme Bourdieu (2003), o movimento feminista não propõe apenas uma conversão das consciências e das vontades, visto que o fundamento do que ele chama de violência simbólica, para além das consciências mitificadas, reside também nas estruturas de dominaçáo que produzem as consciências. Conforme o autor, para se chegar a uma ruptura dessa relação de cumplicidade que as vítimas da dominação simbólica têm com os dominantes, é necessária uma transformação radical "[...] das condiçôes sociais de produção das tendências que levam os dominados a adotar, sobre os dominantes e sobre si mesmos, o próprio ponto de vista dos dominantes." (BOURDIEU, 2003g, p.54). Nesse sentido, há uma relação de dominação funcionando por meio de uma cumplicidade de tendências, onde uma depende profundamente da outra, tanto para sua transformação como para sua perpetuação.

Da perpetuação ou da transformação das estruturas de que tais disposições são resultantes (particularmente da estrutura de um mercado de bem 
simbólicos cuja lei fundamental é que as mulheres nele são tratadas como objetos que circulam de baixo para cima). (BOURDIEU, 2003, p. 55).

Sendo assim, na diferença repousa sua reprodução e a possibilidade de mudança, mas ela precisa ser desmitificada, desnaturalizada, compreendida do ponto de vista da ciência e das práticas dos sujeitos.

O conceito de gênero já não permite definir a mulher de maneira essencialista, determinando-a pelo seu ser biológico. Laqueur (2001) afirma que as diferenças sexuais como absorvemos, bem como seus significados, já fazem parte da lógica que impulsiona a escrita: Através da "literatura", representação genérica, é dado o conteúdo. Não só as atitudes com relação à diferença geram e "estruturam os textos literários", como os textos geram a diferença sexual. (LAQUEUR, 2001, p. 128).

Nesse sentido, Laqueur (2001) afirma que as diferenças de gênero precederam as diferenciaçóes de sexo historicamente. O protestantismo do século XIX incluiu juízos de valores sobre sexualidade e isso afetou a organização dos relacionamentos entre mulheres, conforme diz Stearns:

A dominação europeia inevitavelmente afetou o status dos homens nativos, forçados a relacionamentos de subordinação. Isso se deu particularmente onde economias agrícolas substituíram a caça e a coleta, como em grande parte da América do Norte. Em muitos casos, ocorreu maior subjugação das mulheres, à medida que os homens afirmavam sua masculinidade de novas formas. A força cultural mais explícita era o cristianismo, cujos missionários tinham fortes convicções de como homens e mulheres deviam se relacionar. A visão cristá, em particular os homens nativos das Américas. (STEARNS, 2007, p. 10).

No entanto, vale ressaltar que isso não ocorreu de forma simples e passiva, pois houve muita resistência, em especial por parte das mulheres, que não estavam nem um pouco à vontade com a nítida perda de espaço que os "novos deuses" propunham em troca da "salvação das almas". Assim, a questáo do poder se afirma pela força de forma explícita quando não consegue seduzir apenas pela violência simbólica, que se institui pela força do habitus que nos fala Bourdieu (2003) e, que de forma ora mais sutil, ora mais explícita, vai se materializando, sendo transmitida aos indivíduos e se tornando norma. 
Bourdieu (2003) fala do capital simbólico, que se expressa em forma de poder por meio do que chama de signos de comunicação, que são, indissoluvelmente, instrumentos de dominação produzidos e reproduzidos nas relaçóes sociais estabelecidas entre homens e mulheres por meio de instituiçóes como a família, a igreja e a escola. Os grupos sociais organizam a sociedade por meio de categorias e rituais míticos, produzindo e reproduzindo as condiçôes de acesso e permanência, da mesma forma como é tratada a sexualidade.

Para uma melhor compreensão de como chegamos a essa realidade e de que maneira ela vem construindo essas relaçôes, faz-se necessário que voltemos nosso olhar para a divisão sexual do trabalho e a segregação feminina na ciência.

\section{Divisão sexual do trabalho e segregação feminina}

Em seu livro A Ciência é masculina? É, sim senhora!, Chassot (2006) traz uma lista de 100 nomes que figuram como personagens muito importantes e que de alguma forma influenciaram a humanidade, sendo que 98\% desses nomes são masculinos, ou seja, figuram na lista apenas duas mulheres: Elizabeth I e Isabel, a Católica ${ }^{1}$. Para Chassot, isso está relacionado com nossa tríplice ancestralidade, que tem sua origem fundada no paradigma greco-judaico-cristão. Tomemos por base a grande diferença entre o número de homens que se dedicam ao conhecimento científico comparado com o de mulheres. Isso nos mostra que, apesar de todos os avanços, ainda hoje vemos que o

[...] número de mulheres que se dedicam às ciências, em termos globais, é significativamente menor do que o de homens; mesmo que se possa dizer que, nas décadas que nos são mais próximas, está havendo uma muito

1. Elizabeth I (1533-1603) foi rainha da Inglaterra e da Irlanda (1558-1603), filha de Henrique VIII, rei da Inglaterra, e de sua segunda esposa, Ana Bolena. Elizabeth exerceu um dos mais extensos reinados da Inglaterra, aliás, as rainhas se destacam na coroa britânica por extensos reinados: Elizabeth reinou 45 anos; a rainha Vitória 64 anos; e Elizabeth II está no poder desde 1953. Elizabeth I enfrentou graves problemas religiosos em seu mandato, pois seu pai, para casar-se pela segunda vez (dos seis casamentos que teve) separou a igreja Inglesa de Roma, dando inicio ao Anglicanismo. Isabel I (1451-1504), conhecida como Isabel, a Católica, foi rainha de Castela com seu marido, Fernando V, rei de Aragão, também conhecido como o Católico, juntos formaram um dos casais ou reinados mais poderosos, os Reis Católicos, e com o casamento uniram reino na Espanha. Foram os reis que financiaram Colombo nas viagens de descobertas, e como consequência fizeram a maior expansão territorial do reino espanhol na América. CHASSOT. A. I. A Ciência é masculina? É, sim senhora! Ed. UNISSINOS, 2.ed. 2006. 
significativa presença das mulheres nas mais diferentes áreas da ciência, mesmo naquelas que antes pareciam domínio quase exclusivo dos homens. Parece que usualmente não se valorizam significativamente as contribuiçôes femininas. (CHASSOT, 2006, p. 87).

Para Carvalho e Montané (2012) reverter as desigualdades de gênero implica, necessariamente, equilibrar a participação entre mulheres e homens em todos os cursos superiores e áreas do conhecimento, sejam estudantes ou docentes, transformando as representaçóes e as práticas masculinas e femininas do conhecimento, assim como do trabalho acadêmico, incluindo mais mulheres na gestão das Instituiçôes de Ensino Superior (IES) e do sistema de ciência e tecnologia. Para isso, seria preciso

transformar as culturas acadêmicas de diferentes departamentos, cursos, disciplinas e áreas do conhecimento, para erradicar obstáculos e formas de discriminação, desvalorização e exclusão sutis baseados em sinais de gênero (CARVALHO; MONTANÉ, 2012, p. 9).

O Censo da Educação Superior em 2010 revela que mesmo tendo crescido o número de mulheres inclusas no ensino superior, elas ainda são minoria entre os docentes, embora sejam maioria no número de estudantes e graduados desde o fim da década de 1990. As mulheres predominam nas profissóes ligadas ao cuidado, na área de educação, saúde ou alimentação, enquanto homens aparecem em profissóes ligadas às finanças, administração ou tecnologia, via de regra, com maior reconhecimento e prestigio no mercado. Mesmo o crescimento da participação feminina sendo relativamente superior aos dos homens, estes são maioria entre os pesquisadores mais qualificados (CARVALHO; MONTANÉ, 2012).

De acordo com Chassot (2006), é necessário considerarmos o quanto nossas origens têm fortes vínculos religiosos, e de como isso tem influenciado no nosso comportamento no que diz respeito à construção do conhecimento científico:

Mesmo que se pudesse contestar que a religião grega não tinha marcas de dominação, não podemos esquecer duas situações: os mitos que se constituíram como se fossem livros sagrados e a filosofia grega, particularmente 
com Aristóteles, se faz sincrética com a escolástica, particularmente na nascente Universidade no mundo ocidental a partir do século XI. (CHASSOT, 2006, p. 46).

Outro ponto interessante se refere ao contexto europeu quando comparado ao latino-americano. Segundo Sterns, as

[...] visóes europeias sobre gênero eram menos igualitárias do que as da maioria dos grupos indígenas, pelo menos até o final do século XIX. Essas visōes eram construídas por pressōes para mudar o sistema para a agricultura e se afastar assim dos conflitos armados, o que teve como inesperada consequência a volta das agressóes dos índios para dentro do grupo, em geral contra as mulheres. Essa situação certamente decorreu da incapacidade dos europeus de admitir o bom funcionamento de outro sistema de gênero diferente do seu. (STEARNS, 2007, 111-112).

Nesse sentido, houve um esforço contínuo dos europeus em substituir o modelo econômico de produção que, necessariamente, acabou alterando as formas de relaçóes entre mulheres e homens, visto que no sistema de caça e coleta as atividades eram divididas, mas não pressupunham hierarquias entre homens e mulheres. A agricultura era apenas de subsistência, sendo responsabilidade das mulheres, mas a partir do momento em que ocorre uma intensificação da produção para gerar lucros, há uma inversão no seu domínio: agora é o homem que passa comandar este setor.

Neste contexto, o homem sempre é tomado como modelo. No que se refere a questão política, Laqueur aponta que:

[...] quando as diferenças foram descobertas elas já eram, na própria forma de sua representação, profundamente marcadas pela política de poder de gênero [...] o sexo tanto no mundo de sexo único como no de dois sexos, é situacional; é explicável apenas dentro do contexto da luta sobre gênero e poder. (LAQUEUR, 2001, p. 22-23).

$\mathrm{Na}$ economia, do ponto de vista do materialismo histórico, constatase que a humanidade não é uma espécie animal apenas, mas constitui-se de uma realidade histórica: 
Viu-se que, biologicamente, os dois traços que caracterizam a mulher são os seguintes: seu domínio sobre o mundo é menos extenso que o do homem; ela é mais estreitamente submetida à espécie. Mas esses fatos assumem um valor inteiramente diferente segundo seu contexto econômico e social. (BEAUVOIR, 1949, p. 73).

Segundo Beauvoir, é nessa perspectiva que a história da mulher é retratada por Engels (1884) em n'A Origem da Família, da Propriedade Privada e do Estado. $\mathrm{Na}$ divisão primitiva do trabalho, os dois sexos se constituem, de certa forma, em duas classes, mas há igualdade entre elas. Assim, enquanto

o homem caça e pesca, a mulher permanece no lar. As tarefas domésticas comportam um trabalho produtivo: fabricação dos vasilhames, tecelagem e jardinagem, e com isso ela desempenha um papel importante na vida econômica. (BEAUVOIR, 1949b, p. 74).

Isso muda radicalmente com a descoberta dos metais (cobre, estanho, bronze e ferro), e a partir daí a agricultura estende seus domínios exigindo trabalho intensivo para desbravar as florestas e fazer produzir os campos:

O homem recorre, então, ao serviço de outros homens que se reduzem a escravidáo. A propriedade privada aparece: senhor dos escravos e da terra, o homem se torna também proprietário da mulher. Nisso consiste 'a grande derrota do sexo feminino'. (BEAUVOIR, 1949, p. 74).

O valor do trabalho doméstico se inverte: o mesmo trabalho que antes dava status à mulher por sua especificidade e domínio no espaço doméstico, passa a ser insignificante quando comparado ao trabalho produtivo do homem, passando a ser apenas um adendo, que náo produz valor de troca, sendo trabalho é transformado em "serviço", gratuidade. Assim, o "direito paterno substitui-se então ao direito materno; a transmissão da propriedade faz-se de pai para filho e não mais da mulher a seu clã. É o aparecimento da família patriarcal baseada na propriedade privada." 
(BEAUVOIR, 1949d, p. 75). Nesse novo modelo, o homem reina soberano, permitindo-se inclusive ao capricho da poligamia, entre outros.

Ainda conforme Beauvouir (1949), referindo-se a Engels, a opressão social sofrida pela mulher é consequência da opressão econômica, e a igualdade só seria possível quando os dois sexos tivessem direitos jurídicos iguais, sendo que essa igualdade demandaria a entrada de todas as mulheres no espaço público. Ao que parece, essa ideia náo estava completamente certa nem completamente errada, visto que a grande indústria moderna requisitou a mulher no espaço público. Entretanto, isto não foi suficiente para solucionar as grandes desigualdades de gênero. A mulher tem ocupado cada vez mais espaços fora do lar, porém não aconteceu o mesmo por parte do homem com o mundo privado. À medida que a mulher tem lutado por novos espaços, sua sobrecarga tem aumentado, pois ela não se desvencilhou das tarefas domésticas. De maneira geral, tem se submetido a uma dupla ou tripla jornada de trabalho para garantir sua presença no espaço público sem abandonar o mundo privado que ainda não conseguiu socializar.

Bourdieu (2003) têm razão ao chamar a atenção para a lógica da economia de trocas simbólicas, que determina às mulheres seu estatuto social de objeto de troca. Por mais que a mulher tenha avançado na conquista de sua liberdade, ela ainda se encontra presa a um código simbólico de pertencimento ao mundo familiar onde tudo lhe compete, afinal, ali ela é "rainha".

Conforme Stearns, em algumas partes do Canadá e na América Latina, os índios foram pressionados pelo catolicismo cristáo, cujos missionários tinham convicçôes de como mulheres e homens deviam se relacionar, onde a visão cristã, em particular do protestantismo do século XIX, "incluía juízos firmes sobre sexualidade, e isso afetou a organização dos relacionamentos entre homens e mulheres nativos das Américas." (STEARNS, 2007, p. 110). Quando o protestantismo, crença predominante nos Estados Unidos, chegou, no final do século XVIII, incitando a conversão religiosa em busca de almas, "sua abordagem foi suplantada por crescentes crenças no papel doméstico quase sagrado da mulher - o que alguns chamavam de o 'ritual da verdadeira feminilidade" (STEARNS, 2007, p. 111).

$\mathrm{Na}$ América do Norte, o contato com os europeus justapôs uma combinação entre agricultura e caça, onde as divisóes de tarefas de acordo como gênero eram explícitas, mas não denotavam grandes desigualdades 
com as presunçóes do patriarcado europeu. Já nos casos principais da América Latina, o contato acabou por sobrepor sistemas patriarcais diferentes, nos quais a desigualdade já se fazia presente antes mesmo da chegada dos europeus, o que serviu para reforçar as desigualdades entre gêneros.

O contato com os europeus em geral piorou as condições das mulheres índias, em parte por causa das reaçóes dos homens índios, mas principalmente porque os europeus tentaram reforçar a hierarquia de domínio masculino. Em segundo lugar, os europeus se declaravam muito chocados com as condiçôes dos índios e convictos, com frequência de estarem ajudando as mulheres. Visóes conflitantes sobre trabalho e sexualidade figuravam com destaque nessa confusão, a qual, por sua vez, tendia a reforçar a propensão para a deterioração na condição das mulheres. (STEARNS, 2007, p. 111).

Porém houve muita resistência, em especial por parte das mulheres na aceitaçáo do novo sistema, no qual a religião entra em cena com a função de garantir a doutrina pela fé, formando assim o "novo modelo" a ser assumido pelas populaçóes ameríndias. Foi assim que os intercâmbios relativos à questáo de gênero tiveram resultados muito complexos e, quando as coisas foram se acomodando, suscitaram alguns ganhos e muitas perdas para as mulheres. Assim, deram-lhes "almas tão boas quanto às dos homens, e algumas imagens religiosas femininas muito positivas, como a de Maria Mãe de Jesus, tornaram-se parte do novo cenário." (STEARNS, 2007d, p. 114). As mulheres sempre foram responsáveis pela tecelagem, mas naquele momento teriam que fazer tecidos para pagar parte dos impostos aos espanhóis, reforçando assim sua essencialidade no sustento da família, o que veio a aumentar a exploração sobre seu trabalho.

Os missionários, ansiosos por impor o casamento cristão, foram fundamentais na fragmentação dos grupos extensivos na forma com que as famílias se constituíam, pois consideravam estes como centro de vício sexual. Tiveram como resultado o isolamento entre as mulheres, enfraquecendo a categoria feminina.

Apesar das conversóes e implicações religiosas sobre a eminente igualdade das almas, náo houve impacto no sentido de igualdade dos gêneros na sociedade maia, enquanto houve redução nas poucas proteções e 
oportunidades que a tradição garantia para as mulheres. $\mathrm{O}$ que houve foi uma fusão cultual, o que Stearns (2007) chama de sincretismo, mas praticamente sem ganhos e com prejuízos para as mulheres.

Conforme Nazzari (2001), em um estudo feito no Brasil sobre mulheres, famílias e mudança social no período entre 1600 e 1900, foi mostrado como os casamentos constituíam arranjos econômicos, nos quais a família da noiva tinha maior influência na decisão do casamento das filhas, determinando inclusive o local de moradia e administração dos bens. $\mathrm{O}$ casamento de uma filha ampliava alianças para a família, trazendo mais um homem para os projetos, sejam eles militares, políticos ou econômicos, empreendidos pela família da noiva. Neste sentido, o dote da filha precedia outros gastos, o que conferia à mulher um poder de equilíbrio ou até certa vantagem com relação ao homem nas decisôes em geral.

Com a descoberta do ouro, dependia-se mais da sorte do que da quantidade de pessoas, assim, "as expediçóes do século XVIII eram menores e exigiam menos desembolso de capital, e seu êxito não dependia do poder do clâ." (NAZZARI, 2001a, p. 87). Este movimento muda a dinâmica social levando a várias transformaçôes:

[...] a mudança de uma sociedade baseada na capacidade militar e na família extensa corporativa para uma sociedade cada vez mais baseada na posse do capital e na capacidade empresarial criou oportunidades que possibilitaram aos filhos homens tornarem-se mais independentes dos pais, ao mesmo tempo em que o comércio permitia que, com relativamente poucos recursos, muitos homens fizessem fortunas. (NAZZARI, 2001, p. 86).

Essa mudança na economia e no comércio transformou o pacto matrimonial, possibilitando aos homens entrarem no mercado matrimonial com maior poder de barganha, passando de escolhidos a escolhedores. Consequentemente, no transcurso à readaptação, houve o enfraquecimento do patriarca e o desaparecimento do dote (NAZZARI, 2001). No decorrer desse processo, percebemos como as relaçôes de gênero são afetadas e determinadas pelos interesses econômicos, refletindo nas relaçóes de poder.

Se o dote possibilitava a permanência da mulher na classe social de sua família, seu desaparecimento trouxe uma grande mudança, "da mulher que mantinha o status da família para a mulher que adotava o status do 
marido.” (NAZZARI, 2001c, p. 270). Ao casarem no período colonial, as mulheres levavam o sobrenome e continuavam, portanto, membros da família de origem. No século XIX, elas não levam mais o dote e passam a adotar o sobrenome do marido, tornando-se independentes da família e dependentes do marido (NAZZARI, 2001).

O código civil de 1917 foi ainda além. Tornou automática a adoção do sobrenome do marido pela esposa e exigiu que o marido sustentasse não só os filhos como também a esposa, tivesse ela trazido bens para o casamento ou não. Desse modo, o código civil legalizou plenamente a mudança de uma instituição do casamento que era principalmente uma relaçáo de propriedade entre iguais, para uma instituição do casamento baseado no relacionamento pessoal entre os cônjuges, no qual as esposas eram em geral economicamente dependentes de seus maridos. (NAZZARI, 2001, 270-271).

Nesse novo sistema, as mulheres ficam disponíveis para aquisição, não mais os homens, e não mais por um preço pago como na sociedade primitiva através do dote, mas pelas promessas de garantia de sustento e "segurança".

$\mathrm{O}$ século XX trouxe alguns avanços e conquistas para as mulheres, entretanto, longe de atingir um patamar de participação social ideal, às mulheres ficaram reservados os lugares secundários tanto na ciência quanto no trabalho e, por que náo dizer, na sociedade de um modo geral. Todavia, é correto afirmar a importância do movimento feminista na valorização da mulher na sociedade.

Para que possamos melhor compreender como as desigualdades de gênero começaram a ser questionadas, passando a ser discutidas e transformadas na sociedade, é necessário que conheçamos a contribuição dada pelos movimentos sociais, especialmente pelo movimento feminista, muito embora não seja pretensão nossa entrar no mérito desta discussão.

Conforme Louro (2002), o feminismo não é uma questão universal entre as mulheres, mas uma luta e uma interpretação política controversa, na qual ser mulher está longe de significar ser feminista. A autora afirma que para a maioria das mulheres de sua geração, o encontro com o feminismo se fez via participação nos movimentos sociais, em lutas políticas concretas, que no Brasil foram se agregando a outras lutas sociais, contra a ditadura, por direitos humanos, pela anistia ou ainda por políticas 
públicas voltadas a melhores condições de vida. No caso dela, esse encontro aconteceu no meio acadêmico: "[...] motivada pela notável ausência das mulheres como sujeito ou como objeto da história (ou, pelo menos da história que se registra nos livros, que se ensina nas aulas).” (LOURO, 2002, p. 12).

Segundo Louro (2002), os estudos acadêmicos que se preocupam em dar visibilidade às questóes que dizem respeito à mulher, são produzidos numa estreita relação com o movimento social, sendo ele o motivador de uma produção teórica e empírica com caráter "subversivo" no interior da academia:

[...] o fazer científico e acadêmico referenciado ao feminismo se assumia politicamente, desafiando a neutralidade e a objetividade táo caras à ciência tradicional. As questóes, formuladas a partir de um novo lugar e por um sujeito, que até então, ficara afastado da construção da teoria e do conhecimento, não se pretendiam distantes das lutas e dos movimentos sociais, ao contrário, nutriam-se deles. (LOURO, 2002, p. 13).

As feministas trouxeram à tona a discussão sobre a produção cultural das diferenças e "possibilitaram com isso pensar as relaçôes de poder que produzem as desigualdades." (SAMPAIO, 2007, p.16). Sobre o conceito de gênero (SAFFIOTTI, 2004), trata-se de um conceito aberto que nos possibilita justificar críticas referentes ao patriarcado, fundamentada na exploração masculina sobre a condição da mulher. Apesar de cada intelectual do feminismo ressaltar um aspecto determinado na questáo de gênero, há uma tendência que todos admitem: gênero é um processo construído socialmente para representar o masculino e o feminino, segundo os valores que a sociedade quer manter.

Entretanto, antes de prosseguirmos nessa reflexão, é necessário dizer o que entendemos por feminismo e a partir de onde estamos falando. $\mathrm{O}$ feminismo, enquanto movimento, é uma filosofia que tem origem na Europa a partir do século XVIII, com discurso intelectual e político que visa à igualdade de direitos e uma vivência humana livre da opressão baseada no gênero.

Os estudos feministas formam um campo plural, polêmico e dinâmico, que vem sendo desafiador e tem como característica o autoquestionamento. Isto implica num fazer científico que remodela a proposta epistemológica e sugere novos olhares nos paradigmas vigentes até então. 
A categoria gênero merece um destaque significativo nesta reflexão. A emergência da categoria representou, pelo menos para aquelas e aqueles que investiram na realidade que ela sugeria, uma virada epistemológica ou uma literatura das mulheres, sobre mulheres e passava-se a analisar a construçáo social do feminino e do masculino, atentando para as formas pelas quais os sujeitos se constituíam e eram constituídos, em meio às relaçóes sociais de poder. (LOURO, 2002, p. 15).

Falar em feminismo implica saber que não existe um único feminismo. Conforme Fougeyrollas-Schwebel (2009), os movimentos feministas, mesmo na sua diversidade, devem ser distinguidos dos movimentos populares de mulheres que não se expóem diretamente pela exigência de direitos específicos para mulheres. A expressão "movimentos de mulheres" é representada pelas mobilizaçóes de mulheres com um único objetivo. Enquanto falar de "movimentos feministas" implica designar sob uma mesma denominaçáo diversas formas de movimentos de mulheres, conhecidos como feminismo liberal ou burguês, feminismo radical, mulheres marxistas ou socialistas, as mulheres lésbicas, negras, entre outras dimensóes e categorias dos movimentos atuais. Na perspectiva feminista,

[...] demandas por direitos iguais abrangem o conjunto das atividades sociais (direitos na família, direitos no trabalho), a primeira onda do feminismo é frequentemente apresentada em torno das reivindicaçóes do direito de voto: de fato é a respeito dessas questóes que as açóes mais espetaculares foram realizadas nos Estados Unidos e no conjunto dos países europeus. (FOUGEYROLLAS-SCHWEBEL, 2009, p. 145).

Para Sampaio (2007), o feminismo é uma teoria política com base na análise das relaçóes entre os sexos, assim como na prática de luta pela libertação das mulheres. Ser feminista requer assumir-se, enquanto ser político, em situação desigual, na busca de relações equânimes, nas quais não há lugar para hierarquias pautadas pela sexualidade.

A história do feminismo pode ser dividida em três momentos, que estudiosos do assunto chamam de "ondas do feminismo": a primeira onda ocorreu por volta do século XIX e início do século XX; a segunda "onda” 
se situa entre as décadas de 60 e 70; a terceira vai da década de 90 até a atualidade, sendo que seu surgimento se deu a partir das demandas de mulheres insatisfeitas com a situação de desigualdade e opressão a que estavam sujeitas, vindo a se contrapor às perspectivas dominantes em diversas áreas da cultura Ocidental. A primeira onda se refere ao movimento ocorrido na América do Norte, que teve como principal bandeira a promoção da igualdade de direitos contratuais e de propriedade para homens e mulheres e o fim dos casamentos arranjados. Ainda no final do século XIX, as feministas incluem em suas pautas a conquista do poder político e começam a fazer campanha por direitos sexuais, reprodutivos e econômicos das mulheres.

Nos Estados Unidos, o fim da primeira onda culmina com a conquista do direito ao voto, com a aprovação da emenda constitucional em 1919, que concede direito ao voto feminino em todos os estados.

O termo "segunda onda" começa a ser usado para descrever o movimento feminista que se preocupa com as desigualdades sociais, culturais e políticas. Surgem então algumas críticas ao movimento de liberação feminina, sobretudo por mulheres intelectuais afro-americanas, argumentando que o movimento teria desconsiderado as diferenças de raça e classe e não daria conta de atingir as questóes que dividiam as mulheres. Em 1963, Betty Friedan escreve Mistica Feminina, livro no qual critica a ideia de que as mulheres se satisfazem apenas com a criação dos filhos e atividades do lar. Conceituado como um dos livros mais influentes do século XX, levanta a hipótese de que as mulheres seriam vítimas de um falso sistema de crenças que exige delas o encontro de identidades e significados para suas vidas por meio de seus maridos e filhos, perdendo, assim, sua identidade para a família.

A terceira onda inicia-se com a década de 90 , no intuito de suprir as "falhas" da segunda onda, visando desafiar as definições essencialistas de feminilidade, que teria colocado ênfase demasiada nas mulheres brancas de classe média-alta. Esta surge em meio à década de 1980 com raízes na segunda onda. Várias feministas negras buscam trazer para o debate consideraçóes de subjetividades relacionadas com a raça, mostrando que a questão de gênero não é única, mas sim imbuída de uma diversidade ampla, quão amplo é o universo humano, dado as diversas características que este contempla. Por isso, o conceito de gênero vem sendo cada vez mais debatido, levando em conta sua ampla complexidade e considerado na diversidade que se inclui, sendo um conceito utilizado para explicar 
os múltiplos universos humanos, bem como suas complexas relaçóes com a sociedade. É muito comum as pessoas definirem gênero com relação apenas ao sexo, fazendo uma confusão entre o conceito de gênero e aspectos da sexualidade. Neste sentido que, no próximo tópico, discutiremos esses dois conceitos procurando compreendê-los como conceitos separados, embora em constante relação.

\section{Gênero e sexualidade}

A sociedade ocidental moderna trata a diferença sexual como suporte primordial e fixo da identidade de gênero, na qual as expressôes anatômicas são responsáveis pela divisão entre homens e mulheres. Isso os obrigaria a se desenvolverem de maneiras diferentes quanto as suas atitudes, emoções, vocaçóes e comportamentos. Essa distinção radical e absoluta entre homens e mulheres, a partir de sua anatomia, se coloca como medida de "normalidade" no que se refere ao gênero, moldando corpos e mentes no sentido de responderem ao que se espera do casal hetero e reprodutor, onde o "normal" é o homem sentir-se masculino e a mulher sentir-se feminina. As pessoas, cujo gênero e identidade social náo combinam com o seu sexo biológico, ou que se identificam com um gênero que não é o que lhe foi estabelecido desde seu nascimento, são consideradas por muitos como desviantes em relação à norma de gênero.

A expressão "identidade de gênero" foi usada primordialmente no campo médico-psiquiátrico justamente para designar o que estas disciplinas consideravam "transtornos de identidade de gênero", isto é, o desconforto persistente criado pela divergência entre sexo atribuído ao corpo e a identificação subjetiva com o sexo oposto. Nos últimos anos, outros campos da ciência, bem como as próprias pessoas que se identificam como travestis, transexuais, transgêneros, trans ou intersexuais têm retomado esse conceito, seja para questionar a perspectiva que avalia tais variaçóes como patológicas, seja para reivindicar direitos relativos ao reconhecimento social da identificaçáo com o sexo assumido pela pessoa quando a aparência e o comportamento são diferentes daqueles esperados para o sexo atribuído no nascimento com base nas características anatômicas. (CARRARA, HEILBORN, 2009, 123-124). 
$\mathrm{Na}$ dinâmica da sociedade ocidental moderna, nascer anatomicamente com características masculinas ou femininas já traz implícita uma série de determinaçôes a serem assumidas conforme as normas e padrôes vigentes. Tais normas vão desde experiências sexuais enquanto homem ou mulher, que constituem os padrôes de gênero, determinando a forma como se deve experienciar o mundo e suas múltiplas relaçóes com a afetividade, até outras situações que lhe serão apresentadas. Isso faz parte do capital simbólico que Bourdieu (2003) trata quando se refere à naturalização da dominação masculina e submissão feminina.

Laqueur (2001) defende que transformaçóes políticas, econômicas e culturais ocorridas no ocidente no século XVIII, criaram o contexto para ser estabelecida a visão contemporânea sobre os sexos, compreendendo-os como totalmente distintos. $\mathrm{O}$ corpo feminino era considerado uma versão inferior e invertida do masculino, mas a importância do prazer sexual era reconhecida para que a reprodução tivesse sucesso. No século XIX, essa visão é substituída por um novo modelo reprodutivo, que defende a existência de dois corpos marcadamente diferentes e de duas sexualidades opostas, no qual se enfatiza o ciclo reprodutivo supostamente automático da mulher, bem como sua pretensa falta de sensação sexual (LAQUEUR, 2001).

[...] os modelos de dois sexos e de sexos únicos haviam sempre existido para aqueles que pensavam na diferença e que não havia qualquer forma científica para distingui-los. $\mathrm{Na}$ verdade, o primeiro deve ter entrado em evidência no Iluminismo, mas o modelo de sexo único não desapareceu. De fato, quanto mais se examinam os registros históricos, menos clara se torna a divisão sexual; quanto mais o corpo existia como fundamento do sexo, menos sólidas se tornavam suas fronteiras. (LAQUEUR, 2001d, p. 8).

Laqueur (2001) aponta em seu livro Inventando o Sexo Oposto que há duas versôes de uma mesma história. Até o século XIII, considerava-se o orgasmo como fator indispensável à concepçáo. Isso toma outro rumo quando se constata que orgasmo e concepção não estão interligados. Já no final do Iluminismo, a ciência médica deixa de considerar o orgasmo feminino irrelevante para a concepção. A princípio, isso se aplicava tanto ao homem quanto à mulher. 
Mas ninguém que tenha escrito sobre esses assuntos sustentou a ideia de que as paixôes e os prazeres masculinos em geral não existiam ou que o orgasmo não acompanhava a ejaculação durante o coito. Porém não era o mesmo para as mulheres. A contingência recém "descoberta" do prazer abriu a possibilidade da passividade e falta de paixão da mulher. A alegada independência da concepção com relação ao prazer criou o espaço no qual a natureza sexual da mulher podia ser redefinida, debatida, negada ou qualificada. E assim seguiram-se as coisas. Infindavelmente. (LAQUEUR, 2001e, p. 15).

A presença ou ausência de orgasmo passa a ser um marco biológico da diferença sexual. Por muito tempo se acreditou que a genitália da mulher era a mesma que a do homem, só que enquanto a deles ficava para fora do corpo, a delas ficava para dentro.

Segundo Laqueur, foi Galleno que desenvolveu, no século II, o mais poderoso e exuberante modelo de identidade estrutural, mas não espacial, dos órgãos reprodutivos do homem e da mulher . Demonstrava com detalhes que as mulheres eram essencialmente homens, nos quais uma falta de calor vital "de perfeição" resultara na retenção interna das estruturas, que no homem são visíveis na parte externa (LAQUEUER, 2001f, p. 16). Ou seja, a linguagem retrata o masculino como perfeito e o feminino como imperfeito, mas complementar ao homem. Por volta de 1800 , a natureza sexual humana muda do antigo modelo, onde homens e mulheres eram classificados de acordo com o grau de perfeição metafísica (calor vital), dando lugar a um modelo pautado nas divergências biológicas. A anatomia e a fisiologia da diferença substituem a metafísica hierárquica na forma de representar a mulher com relação ao homem.

No final do século XIX, buscou-se demonstrar as diferenças baseadas na natureza. Para Laqueur (2001), foi por meio da biologia e da fisiologia celular que se fundamentou explicações quanto ao fato de as mulheres serem consideradas passivas e variáveis, entre outros adjetivos atribuídos ao gênero feminino. Ele admite que não consegue:

[...] elaborar completamente a ligação que se estabelece entre as diferenças biológicas e as resultantes diferenciações "psicológicas e sociais", ainda assim justificava os respectivos papéis culturais do homem e da mulher com uma audácia fantástica. (LAQUEUR, 2001, p. 18). 
Sendo assim, estabeleceram-se de forma primordial as irredutíveis distinçóes entre os sexos e o lugar que cada um deve ocupar na sociedade. Ao submeter homens e mulheres às definiçóes sexuais, fundamentadas nos critérios biológicos, normas que definem a existência de dois sexos ou de duas formas apenas de se viver a sexualidade são estabelecidas. Cristalizamse, junto aos sexos masculino e feminino, os estereótipos de gênero - "capital simbólico" - pela definição clara de papéis a serem desempenhados na sociedade com base no sexo. Nega-se, assim, toda e qualquer forma de expressão e vivência da sexualidade que fuja das normas ou se contraponha ao estabelecido socialmente: "o sexo, tanto no mundo de sexo único como no de dois sexos, é situacional; é explicável apenas dentro do contexto da luta sobre gênero e poder." (LAQUEUR, 2001, p. 23).

Para finalizar, frisamos que, conforme Laqueur (2001) tenta mostrar com base em evidências históricas, tudo que se queira dizer sobre sexo, seja qual for a forma que este seja compreendido, já contém em si uma reivindicação sobre o papel de gênero.

\section{CONSIDERAÇÕES FINAIS}

A partir do que foi exposto nesse capítulo, parece claro que falar em gênero implica, indubitavelmente, em falar de uma identidade de gênero. Tal identidade é forjada no cotidiano a partir do comportamento dos indivíduos e do que Bourdieu (2003) chamou de habitus. Isto quer dizer que a compreensão de gênero está relacionada à percepção subjetiva de ser masculino ou feminino, conforme os atributos, comportamentos e papéis convencionalmente estabelecidos para homens e mulheres no contexto social. No intuito de garantir a permanência desses papéis sociais, a própria sociedade cria um poder simbólico que restringe a capacidade crítica dos sujeitos de se perceberem no contexto social em que estão inseridos. Porém, dada a dinâmica da sociedade, os elementos reagentes não permitem que essa subordinação seja perene. Contrariamente, a sociedade se torna uma arena de conflitos na qual gênero, ciência, sexualidade e trabalho, entre outros elementos, entrecruzam-se enquanto categorias históricas e acabam por se construir e se transformar através da participação política dos sujeitos nos movimentos sociais. Nesse sentido, compreendemos que as relaçóes de gênero tendem a se transformarem cotidianamente. 


\section{REFERÊNCIAS}

BEAUVOIR, S. de. O segundo sexo. Tradução de Sérgio Milliet, v.2. Rio de Janeiro: Nova fronteira, 1949.

BOURDIEU, P; A dominaçáo masculina. 3. ed. Rio de Janeiro. Bertrand Brasil, 2003.

CARRARA, S. Educação, diferença, diversidade e desigualdade. In: (Org.). Gênero e diversidade na escola: formação de professoras/res em Gênero, Orientação Sexual e Relaçóes Étnico-Raciais. Rio de Janeiro: CEPESC, p.13-183, 2009.

CARVALHO, M. E. P.; MONTANÉ, A. Políticas de equidade de gênero na educação superior na Espanha e no Brasil; Avanços e Limites [1]. Labrys, estudos feministas, julho/dezembro de 2012. CHASSOT, A. A ciência é masculina? É, sim senhora! 2. ed. São Leopoldo: Unisinos, 2006. ENGELS, F.; MARX, M. O manifesto comunista. 5. ed. Tradução de Maria Lucia Como. Rio de Janeiro: Paz e Terra, 1998.

FOUGEYROLLAS-SCHWEBEL, D. Movimentos feministas. In: HIRATA, H. et al (Orgs.). Dicionário crítico do feminismo. São Paulo: Editora UNESP, 2009.

GEBARA, I. O que é teologia feminista. São Paulo: Brasiliense, 2007.

GODELIER, M. As relações homem-mulher: o problema da dominação masculina. Encontros com a civilizaçáo brasileira. Rio de janeiro, v. 3, n. 8, p. 9-30, 1980.

HEILBORN, M. L. Gênero e diversidade na escola: A ampliação do debate. In:

(Org.). Gênero e diversidade na escola: formação de professoras/res em gênero, orientação sexual e relações étnico-raciais. Rio de Janeiro: CEPESC, p.11-13, 2009.

HIRATA, H.; LABORIE, F.; LE DOARÉ, H.; SENOTIER, D. (Orgs.). Dicionário crítico do feminismo. São Paulo: UNESP, 2009.

LAQUEUR, T. Inventando o sexo: corpo e gênero dos gregos a Freud. Rio de Janeiro: Relume Dumará, 2001.

LOURO, G. L. (Org.). O corpo educado: pedagogias da sexualidade. 2. ed. Traduçáo de Tomaz Tadeu da Silva. Belo Horizonte: Autêntica, 2007.

MATOS, M. I. S. Outras histórias: as mulheres e estudos dos gêneros-percursos e possibilidades (Org.). In: Gênero em debate: trajetória e perspectivas na história Contemporânea. São Paulo: Educ. 1997.

MURARO, R. M. Aspectos históricos e políticos da violência contra as mulheres. In:

Guerreiras: herança sem testamento. n. 126, CEPAT: Curitiba, 2005.

NAZZARI, M. O desaparecimento do dote: mulheres, famílias e mudança social em São Paulo, Brasil, 1600-1700. São Paulo: Companhia das Letras, 2001. 
SAFFIOTI, Heleieth. Gênero, patriarcado, violência. São Paulo: Fundação Perseu Abramo, 2004.

SAMARA, E. M. (Org.). Gênero em debate: trajetória e perspectivas na história Contemporânea. São Paulo: Educ. 1997.

SAMPAIO, D. F. Relaçóes de gênero na indústria automotiva: a problemática da divisão sexual do trabalho e da divisão essencializada da mulher. Um estudo de caso. 2007. 176 p. Dissertaçâo - (Mestrado em Sociologia) - Universidade Federal do Paraná, Curitiba, 2007.

SCOTT, J. Gênero uma categoria útil de análise histórica. Mulher e realidade: mulher e educação. Porto Alegre, Vozes, v.16, n.2 julho/dez, 1990.

STEARNS, P. N. História das relaçóes de gênero. Rio de Janeiro: Garamond, 2007.

TOLEDO, C. Mulheres o gênero nos une, a classe nos divide. São Paulo: Xamã, 2000. 


\title{
"MAIS CEDO OU MAIS TARDE SUA MULHER IRÁ DIRIGIR": IDENTIDADES DE GÊNERO EM ANÚNCIOS DE CARRO
}

\author{
Pascoalina Bailon de Oliveira Saleh \\ Universidade Estadual de Ponta Grossa
}

\section{INTRODUÇÃO}

Neste capítulo me proponho a refletir sobre a identidade de gênero tomando como foco o modo como homens e mulheres são representados na publicidade, mais especificamente em anúncios de carros.

A minha opção por este recorte se justifica pela maciça presença do anúncio publicitário em nosso cotidiano e pela importância que tem o automóvel em nossa sociedade em termos de projeção de identidades sociais: de gênero, de classe social, de estilo de vida, etc.

Para situar a questão, tomo a linguagem na sua condição de prática social, a partir da qual os sentidos e os sujeitos são constituídos. Isso implica reconhecê-la em sua dimensão discursiva, que se produz através de sua materialidade específica, a língua (PÊCHEUX, 1990; ORLANDI, 1996). A partir dessa posição teórica, analiso alguns anúncios da mídia impressa e televisiva procurando explicitar o papel da linguagem nas configuraçóes identitárias de gênero. Dessa forma, volto-me para os processos de construção de sentidos em anúncios publicitários de carro, buscando identificar mecanismos linguísticos, discursivos e textuais relacionados a esta construção.

Com isso, espero, na esteira do que propóe Orlandi (2012), contribuir para uma reflexão sobre o lugar da linguagem em uma educação que se 
fundamente no reconhecimento tanto da reprodução como da resistência, da ruptura, dos movimentos dos sujeitos, dos sentidos, da sociedade e da história.

Situando teoricamente o tema: discurso, sujeito e identidade

Do ponto de vista dos estudos sociológicos, a identidade decorre das relações sociais, as quais são, acima de tudo, relações de poder construídas e exercidas nas diversas instituiçóes sociais: família, grupo de amigos, escola, igreja, trabalho, mídia, etc. Dessa forma, assume-se que é a partir das relaçóes sociais que se constroem as diversas facetas identitárias constitutivas do sujeito, as quais não se definem de forma isolada, mas na interação umas com as outras. Nesse contexto teórico, ser homem ou mulher não é algo dado biologicamente, mas aprendido nas interaçôes sociais que ocorrem desde que nascemos, algo que tem sido constantemente lembrado em estudos sobre o tema. Essa "aprendizagem" se mantém por toda a vida, uma vez que os valores sociais e culturais variam no tempo, no espaço e nos diferentes grupos e segmentos sociais (SEFFNER, 2008).

Para exemplificar este estado de coisas, podemos pensar na entrada da mulher no mercado de trabalho, território exclusivo dos homens até pouco tempo atrás, com exceção de alguns setores profissionais como o trabalho doméstico, a enfermagem e a docência; ou na adesão dos homens a cuidados estéticos, antes restritos às mulheres. Como nenhuma transformação social se dá isoladamente, essas duas mudanças se dão de forma solidária entre si e a outros aspectos da sociedade.

De fato, diversos dados e análises indicam que a distribuição de poder entre homens e mulheres na nossa sociedade está se alterando em direção a uma posição mais equitativa, porém, ainda se encontra longe do equilíbrio. Isso é confirmado pelos dados divulgados pelo IBGE no dia 8 de março de 2013, Dia Internacional da Mulher, os quais dão conta de que no Brasil as mulheres recebem $72,3 \%$ da remuneração paga aos homens.

A diferença de remuneração entre homens e mulheres, além de evidenciar a identidade profissional como mais uma posição que faz parte da organização social da construção relacional dos sexos, revela a dimensão de poder e conflito presente nessa organização. Entretanto, essa dimensão fica muito mais evidenciada quando se cruza este dado com a questão racial: no Brasil os negros e pardos ganham menos que os brancos, e as mulheres 
negras ainda menos que os homens negros. Essa diferença tem reduzido, mas continua muito alta (era de $46,4 \%$ em 2010) ${ }^{1}$.

Pode-se sintetizar essa problemática com o que diz Seffner (2008):

O conceito de gênero enfatiza a construção relacional do sexo e a organização social desta construção, entendendo que ela é uma construçáo histórica e que precisa ser entendida a partir de sua articulação com outras categorias sociais como classe social, raça/etnia, geração e sexualidade, para citar algumas das mais importantes. A noção de poder que está presente nessa relação introduz aí a dimensão de conflito, uma vez que as mulheres e os homens não são apenas mulheres ou apenas homens, mas são muitas outras coisas ao mesmo tempo. Isso significa dizer que não existe uma essência de mulher ou de homem nem a possibilidade de uma solidariedade dada a priori, a partir de uma única posição, neste caso, a partir da posição de gênero. (SEFFNER, 2008, p. 26).

Porém, gostaria de propor um deslocamento dessa perspectiva, brevemente esboçada, que entende o sujeito e suas identidades como resultantes das relaçóes sociais, de forma que seja possível nos perguntarmos qual é o papel da linguagem nesse processo.

Para isso, é preciso considerar que o sentido das palavras, assim como de todo e qualquer signo, não decorre de uma relação de literalidade com o significante (PÊCHEUX, 1995), o que quer dizer que as palavras ganham sentido a partir das condiçóes em que o texto é produzido. Dessa forma, o sentido também não está na materialidade do texto em si, mas na relação que este mantém com quem o produz, com quem o lê, com outros textos (intertextualidade) e com outros discursos possíveis (a memória e a interdiscursividade). Isto significa tomar não só as circunstâncias de enunciação imediatas, mas também o contexto social, histórico e ideológico como constitutivos da linguagem e do próprio sujeito (ORLANDI, 1996). O discurso materializa ideologias constituídas pela sociedade, logo "não há discurso sem sujeito e não há sujeito sem ideologia” (ORLANDI, 2012).

Assim, para situar os anúncios em questão na rede de sentidos que lhes dá sustentação, e a partir da qual se definem as identidades de gênero,

1. Disponível em: <htttp://g1.globo.com/economia/noticia/2011/05/diferenca-do-salario-entrebrancos-e-negros-cai-mas-ainda-e-de-464.html>. Acesso em: 02 abr. 2012. 
reconheço no anúncio publicitário um espaço privilegiado de manifestação de discursos que materializam ideologias constituídas pela sociedade, ou seja, as propagandas se constroem a partir do que já foi dito, de discursos que são a materialização da ideologia, aqui entendida não como ocultação dos sentidos, mas como mecanismos que produzem a naturalização dos sentidos (ORLANDI, 1996), isto é, "evidências que fazem com que uma palavra ou um enunciado 'queiram dizer o que realmente dizem"' (PÊCHEUX, 1995, p. 160) e não outra coisa.

Nessa perspectiva teórica, o sujeito não é o centro e origem do seu dizer, mas, inscrito numa memória de dizeres, é uma construção polifônica na qual ressoam diversas vozes e da qual depende a sua própria possibilidade de produzir sentido. Igualmente, toda interpretação se dá no interior das condições de produção, isto é, como efeito da exterioridade (ORLANDI, 1996). Com isso, evidencia-se a dinâmica interacional subjacente a toda prática discursiva: os sentidos são construídos pela negociação entre sujeitos marcados por esses diversos aspectos das condiçóes de produção.

Como anunciado na introdução, a linguagem é tomada na sua condição de prática social a partir da qual os sentidos e os sujeitos são constituídos. Tomar a linguagem nessa perspectiva implica reconhecê-la em sua dimensão discursiva, que se produz através de uma materialidade específca: a língua. Já o texto é produto da atividade discursiva, objeto empírico que guarda as marcas discursivas a serem apreendidas pela análise.

No entanto, em toda realização de linguagem a língua não é apenas pressuposta, mas lugar de desestabilização, de pontos de deriva, que faz emergir a subjetividade:

[...] todo enunciado é intrinsecamente suscetível de se tornar outro, diferente de si mesmo, se deslocar discursivamente de seu sentido para derivar para outro [...]. Todo enunciado, toda sequência de enunciados é, pois, linguisticamente descritível como uma série (léxico-sintaticamente determinada) de pontos de deriva possíveis, oferecendo lugar à interpretação. (PECHEUX, 2005, p. 53).

Por isso, cada enunciado é um acontecimento singular, cuja produção e interpretação supóem um processo no interior da língua e no interior de vários discursos, num processo que ao mesmo tempo (re)produz e 
desloca sentidos. Consequentemente, a identidade, em seus múltiplos e cambiantes aspectos, se define a partir dos discursos em que somos significados e significamos o mundo, ainda que imaginariamente a tomemos como uma unidade estável e homogênea.

$\mathrm{Na}$ sociedade contemporânea, o anúncio publicitário é um recurso fundamental não só para manter as necessidades e demandas da clientela já atingida por um determinado produto ou marca, mas também para suscitá-la em novos consumidores. Assim, os produtos não são apresentados por si sós, mas em referência aos seus usuários ou potenciais usuários, os quais se constituem a partir de determinadas formaçóes discursivas, e, portanto, de determinados valores, a partir dos quais se situam as relaçóes sociais. Com base nesses referenciais, o anúncio simula ou constrói o perfil do produto, ou seja, a partir do "espaço" que se pretende que ele ocupe na sociedade. Dessa forma, seu objetivo não é informar sobre o produto, mas ofertá-lo, ou seja, apresentá-lo para que seja adquirido, conforme a ótica de mercado (CAROZZA, 2010).

Partindo do princípio de que a análise do discurso trabalha no entremeio (ORLANDI, 2012), procurando explicitar o ponto de encontro entre histórico e o ideológico no funcionamento da linguagem e do sujeito, devemos nos perguntar como nos constituímos homens e mulheres. Esta indagação nos remonta ao Iluminismo, momento em que se constituiu a forma de sujeito moderna, que é burguesa e estruturalmente masculina, muito embora suas raízes venham da Antiguidade:

[...] o chamado Ocidente é evidentemente uma construção histórica do próprio Iluminismo. Na medida em que esta construção e a sua ideologia de legitimaçáo que remonta até à Antiguidade ocidental concorreu para a constituição da forma do sujeito moderna, capitalista, masculina e permeada pela ideologia do valor e da dissociação, pode-se falar com certa justificação de uma "forma do sujeito ocidental". E é fácil de comprovar que a forma de reflexão ideológica desta relação já desde o protestantismo, mas definitivamente desde o Iluminismo, se define essencialmente pelo objetivismo e pela misoginia, pela homofobia, pelo racismo e pelo antissemitismo aberto ou latente. (KURZ, $2003^{2}$ - ênfases do autor).

2. A versão aqui citada é a tradução do artigo original, disponibilizada na página <http://antivalor. atspace.com/Exit/kurz309.htm>. Acesso em: 02 abr. 2012. 
Sob a égide dessa ideologia, constituíram-se os estados modernos capitalistas, nos quais o sujeito é definido a partir do jurídico, com seus direitos e deveres e sua livre circulação social (ORLANDI, 2012). Como um desdobramento desse movimento, o sujeito é individualizado pelo Estado, pelas instituiçóes e pelos discursos que os constituem, resultando "em um indivíduo ao mesmo tempo responsável e dono de sua vontade" (ORLANDI, 2012, p. 154).

No entanto, o sujeito moderno vem sofrendo deslocamentos (HALL, 2005) no interior do próprio capitalismo. Especialmente na segunda metade do século XX, teorias de diversas áreas, tanto nas ciências sociais como nas humanas (inclusive na linguística saussuriana), póem em xeque essa forma de sujeito. Vale ressaltar que uma dessas frentes foi o feminismo, entendido tanto como crítica teórica quanto como movimento social $^{3}$. O feminismo chamou a atenção para a construção política e social do gênero alicerçada na hegemonia masculina.

Ocorre que, embora a ideologia determine a rede de sentidos à qual o sujeito deve vincular-se, ela não exclui a contradição inerente a este movimento, pois o funcionamento do simbólico é aberto à falha, ou seja, o real não se deixa jamais apreender em sua totalidade pelo simbólico, o que garante o movimento e o deslocamento na rede de filiaçóes de sentido, como afirma Pêcheux:

[...] todo discurso é o índice potencial de uma agitação nas filiaçôes sócio-históricas de identificaçáo, na medida em que ele constitui ao mesmo tempo um efeito dessas filiaçôes e um trabalho (mais ou menos consciente, deliberado, construído ou não, mas de toda forma atravessados pelas determinações inconscientes) de deslocamento no seu espaço: não há identificação plenamente bem sucedida, isto é, ligação sócio-histórica que não seja afetada, de uma maneira ou de outra, por uma 'infelicidade' no sentido performativo do termo - isto é, no caso, por um 'erro de pessoa', isto é, sobre o outro, objeto de identificação. (PÊCHEUX, 2008, p. 56-57).

A partir desse referencial teórico, neste trabalho me proponho a descrever e interpretar mecanismos linguísticos, discursivos e textuais empregados

3. Contemporâneo de outros movimentos contra o racismo, o imperialismo, a homofobia e a dominação de classes. 
em propagandas de carros. Procurarei reconhecer os sentidos explícitos e implícitos que eles produzem e reproduzem e como eles contribuem para construir o conceito de homem ou mulher no anúncio em questão.

\section{Identidades de gênero em anúncios de carros}

O título que propus para este texto, "Mais cedo ou mais tarde sua mulher irá dirigir", foi extraído da propaganda de um dos maiores sucessos da indústria automobilística de todos os tempos: o Fusca, da Volkswagen. $\mathrm{O}$ anúncio foi publicado nos EUA nos anos 60 e teve sua versão levada a público também aqui no Brasil. Quando a versão em português caiu em minhas máos por acaso, enviada por e-mail, achei que embora meu propósito fosse falar da publicidade atual de carros, essa peça, apesar de veiculada há meio século, poderia contribuir bastante para a discussão. Vou focar aqui na versão brasileira, mas tratarei de alguns aspectos da versão em inglês ${ }^{4}$, pois eles são bastante significativos para a entendermos as representaçôes atuais de gênero.

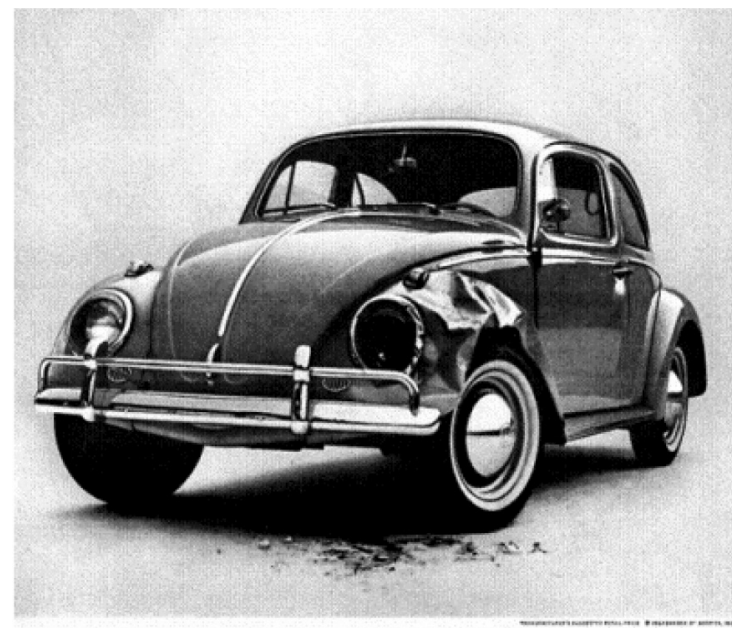

\section{Mais cedo ou mais tarde sua esposa vai dirigir. Esta é uma das razões para você possuir um Vollkswagen}

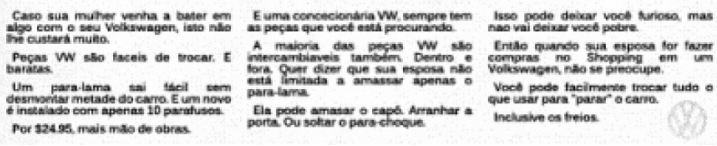

Versão em português: http://blogs.estadao.com.br/reclames-do-estadao/tag/fusca/

4. Disponível em: <http://ideagenda.posterous.com/sooner-or-later-your-wife-will-drive-homeone>. Acesso em: 02 abr. 2012. 


\section{"Mais cedo ou mais tarde sua esposa vai dirigir. Esta é uma das razóes para você possuir um Volkswagen.}

Caso sua mulher venha a bater em algo com o seu Volkswagen, isto não lhe custará muito. Peças VW são fáceis de trocar. E baratas.

Um para-lama sai fácil sem desmontar metade do carro. E um novo é instalado com apenas 10 parafusos.

Por $\$ 24,95$ mais mão de obras.

E uma concessionária VW sempre tem as peças que você está procurando.

A maioria das peças do VW são intercambiáveis também. Dentro e fora. Quer dizer que sua esposa não está limitada a amassar somente o para-lama.

Ela pode amassar o capô. Arranhar a porta. Ou soltar o para-choque.

Isso pode deixar você furioso, mas não vai deixar você pobre.

Então quando a sua esposa for fazer compras no Shopping em um Volkswagen, não se preocupe.

Você pode facilmente trocar tudo o que [ela $\left.{ }^{5}\right]$ usar para "parar" o carro.

Inclusive os freios."

Nos dias atuais, esta peça seria considerada politicamente incorreta, como, aliás, lembra o blog do qual a retiramos. No entanto, o sentido de rebaixamento da mulher que ela produz, seja pelo que é dito literalmente, seja pelo efeito de sentido irônico do texto, está longe de ser superado em nossa sociedade, muito embora tenha sofrido deslocamentos ao longo da história recente. $\mathrm{O}$ ápice da ironia - que denuncia um enunciador claramente masculino - é atingido no fecho e para ele contribuem de forma mais expressiva, mas não exclusiva, as aspas em "parar" e o advérbio "inclusive": "Você pode facilmente trocar tudo o que [ela] usar para 'parar' o carro. Inclusive os freios". Ainda hoje não é incomum nos deparamos com textos nos quais as mulheres são representadas como incapazes ou menos capazes que os homens para dirigir, como nos lembra, por exemplo, o ditado: "Mulher no volante, perigo constante". Discursivamente, este ditado e a peça se filiam a uma mesma formação discursiva e ideológica que necessariamente diz respeito à configuração do sujeito moderno, burguesa

5. Nosso acréscimo, considerando o sentido do texto e a versão em inglês. 
e estruturalmente masculina, como vimos acima, e na qual todos nós nos configuramos como sujeitos.

É de se notar que a peça não se limita a representar a mulher como incapaz para dirigir. Num cenário de consumo e, portanto, capitalista, ela póe o homem no centro de tudo: ele não só é o proprietário do carro, mas detém o controle das finanças do casal e da família, como se lê no enunciado: "Isso pode deixar você furioso, mas não vai deixar você pobre"; por outro lado, a mulher é representada como fútil, como é sugerido no enunciado: "Entáo quando a sua esposa for fazer compra no shopping em um Volkswagen não se preocupe.”

Parece-me, então, que podemos reconhecer no funcionamento desse anúncio publicitário uma característica fundamental que diz respeito à constituição do sujeito moderno e à sua individualização (ORLANDI, 2012), a qual é mobilizada por Carozza (2010, p. 13) na tentativa de dar conta do funcionamento do anúncio contemporâneo: "a publicidade vai procurar falar a todos ao mesmo tempo ou, pelo menos, a todos os 'potenciais' consumidores do produto anunciado. Ela constrói, dessa forma, um determinado tipo de leitor - um conjunto de leitores - para o anúncio". Segundo o autor, embora procure falar a todos ao mesmo tempo, o discurso publicitário contemporâneo busca também individualizar o seu leitor: "falando a todos", a publicidade "procura também individualizar os sujeitos, como se estivesse, na sua forma de dizer, falando a cada um particularmente". (CAROZZA, 2010, p. 13). Ou seja, seu modo de funcionamento busca também como efeito a individualização do sujeito. $\mathrm{O}$ autor aponta como estratégia de individualização o "uso do você como artifício de aproximação com o leitor" (CAROZZA, 2010, p. 123). Dessa forma, "são dois movimentos num único funcionamento capaz de produzir um efeito de identificação no sujeito enquanto um consumidor pertencente a uma determinada categoria, mas que mantém sua singularidade" (CAROZZA, 2010, p. 123). No anúncio em questão, o locutor também se dirige a "você", e essa estratégia enunciativa obviamente visa à identificação especificamente do leitor masculino. De homem para homem, poderíamos dizer parafraseando o bem sucedido slogan das propagandas da rede varejista Marisa: "De mulher para mulher, Marisa.".

Se formos à versão americana (Anexo), veremos que a posição de poder do homem é ainda mais acentuada: o exórdio da peça é "Mais cedo ou 
mais tarde, sua mulher vai [dirigir*] para casa", no qual a expressão "para casa" evidencia ainda mais o restrito campo de ação da mulher, cuja referência é o lar, com toda a rede de sentidos que essa palavra evoca. $\mathrm{O}$ enunciado de abertura reafirma essa posição, talvez com o efeito de sentido de ironia ainda mais acentuado do que na versão em português: "As mulheres são meigas e gentis, mas elas batem/acertam nas coisas". Na primeira parte do enunciado, as mulheres são caracterizadas com os adjetivos "meigas" e "gentis" e, na segunda, afirma-se que as mulheres "batem nas coisas"; as duas partes são relacionadas pela conjunção contrajuntiva "mas", cuja orientação argumentativa aponta em direção contrária ao que está posto na parte inicial (DUCROT, 1987), o que contribui decisivamente para o efeito de sentido de ironia do enunciado.

Que sentidos essa peça produziu na mulher dessa época? Como a mulher da época reagiria a essa provocação? Seria ela de fato interpretada como provocação por boa parte das mulheres? Obviamente os sentidos produzidos nos anos 1960 náo são os mesmos dos atuais. Justamente por ser situado historicamente, assim como todo o texto, o enunciado "Mais cedo ou mais tarde sua esposa vai dirigir" só pôde se realizar - como exórdio de um anúncio publicitário, é preciso ressaltar - porque essa formulação já era possível nessa época, embora não o fosse um século antes, por exemplo. Não podemos nos esquecer de que essa peça é contemporânea de um período de significativos deslocamentos ideológicos e discursivos, nos quais se situam o feminismo, e já vinham se delineando desde a segunda metade do séc. XIX.

Mas este anúncio me dá a oportunidade de refletir sobre um aspecto que muitas vezes nos passa despercebido: discursos estão impregnados em nosso corpo e definem até nossos movimentos e gestos mais sutis; definem a nossa relação com o nosso corpo e, consequentemente, com o ambiente a nossa volta. Há poucas décadas, nas famílias que tinham condições de comprar um carro, os rapazes aprendiam a dirigir cedo, na maioria das vezes ensinados pelo próprio pai ou por um irmão, amigo ou vizinho mais velho. Em geral as meninas não tinham a mesma oportunidade porque na rede de sentidos em que homens e mulheres eram significados e se significavam, o espaço que era destinado às mulheres era

6. "Sooner or later, your wife will drive home [...]"

7. "Women are soft and gentle, but they hit things." 
o doméstico, como também sugere o anúncio. Nessa mesma época, os brinquedos industrializados começaram a se espalhar e, obviamente, os meninos ganhavam carrinhos, e as meninas ganhavam bonecas, prática que ainda persiste, mesmo que com deslocamentos de sentido. Também obviamente, para as mulheres dessa geração aprender a dirigir e lidar com o carro, de maneira geral, era muito mais complicado do que para os homens, porque os sentidos em circulação as excluíam desse universo, contribuindo para definir inclusive sua percepção física do ato de dirigir. Mas o referencial era masculino igualmente no que se refere, por exemplo, ao projeto do carro e ao estilo de quem as ensinava a dirigir. Atualmente, embora esse distanciamento tenha diminuído, ele ainda é muito significativo. Como veremos nos anúncios contemporâneos e em outros discursos do cotidiano, o carro ainda é predominantemente apresentado como dizendo respeito ao homem.

Desenvolvendo um pouco mais o que foi dito acima, vale lembrar que, se atualmente já se admite meninas brincarem de carrinho, é muito mais raro admitir-se que meninos brinquem de boneca. Paralelamente, se as mulheres conquistaram o direito de trabalhar fora, ainda é muito menor a proporção de homens que assumem ou dividem equitativamente as tarefas domésticas. Um relatório da Organização Internacional do Trabalho, divulgado em 18 de julho de 2012, mostra que no Brasil as mulheres trabalham por semana cerca de cinco horas a mais que os homens ${ }^{8}$. No total, os homens têm jornada de 53 horas semanais, enquanto as mulheres trabalham 58. Porém, desse total, as mulheres dedicam 22 horas para casa e os homens apenas nove horas e meia. Mas é igualmente significativo que esse tempo dedicado pelo homem ao trabalho doméstico seja preenchido principalmente por tarefas como ir ao supermercado e levar as crianças à escola.

Vou agora me reportar a uma campanha contemporânea da Fiat, veiculada em 2009. Trabalhei com uma peça impressa dessa campanha em uma palestra para professores do ensino básico9. À época, meu objetivo era tomá-la como um exemplo de violação dos princípios éticos e mesmo

8. Disponível em: <http://oglobo.globo.com/economia/no-rio-22-dos-trabalhadores-demorammais-de-uma-hora-para-chegar-ao-emprego-diz-oit-5520298>. Acesso em: 02 abr. 2012.

9. Projeto de extensão da UEPG, intitulado "Educação para o Consumo Responsável" e realizado entre 2009 e 2011, sob a coordenação do Prof. Dr. Abdala Mohamed Saleh. Conferir Saleh \& Saleh $(2010 ; 2012)$. 
legais. Inicialmente só havia tido acesso a essa versão, veiculada na revista Época, n. 569. No entanto, quando comecei a dirigir a atenção para as representaçôes de gênero, fiz uma busca na internet para tentar encontrar alguma referência quanto à peça selecionada, porém só encontrei comentários em relação a uma propaganda da mesma campanha, mas criada para a $\mathrm{TV}^{10}$. Náo me surpreendi muito quando me deparei com a informação de que, em menos de um mês de exibição, a versão para a TV fora tirada do ar por uma decisão do CONAR - Conselho de Autorregulamentação Publicitária.

Não há fala dos personagens na película em questão. Um casal se desloca em um carro prata importado e para em um semáforo. Logo em seguida chega ao lado um carro preto da Fiat, o Novo Stilo Black Motion. O casal se volta para o carro recém chegado e o rapaz, que é o motorista, observa o carro como se observasse o corpo de uma mulher. De repente, para surpresa e decepção do rapaz, a moça que estava ao seu lado aparece no carro da Fiat, também no banco do carona, abaixa o vidro com um ar debochado, aumenta o som do carro, que sai na frente do outro, embora não tenha motorista. Ao fundo, uma voz masculina diz "Novo Stilo Black Motion: para poucos e maus".

Esse anúncio não se dirige ao seu interlocutor através do "você", como faz o texto da Volkswagen, mas me parece que a busca pelo efeito de escuta individual está presente na medida em que o anúncio é construído de forma a conduzir o interlocutor a se identificar com a posição do enunciador.

O comercial é comentado em diversos $b \operatorname{logs}^{11}$, nos quais é salientada a qualidade técnica e estética do trabalho e/ou a questáo ética implicada na apologia ao "mau" e/ou na representação da mulher como interesseira, a "Maria gasolina". A questão do "mau", do bad boy, foi mais comentada do que a representação da mulher.

Algo que não foi comentando explicitamente nos blogs que visitei é o fato de a mulher estar sempre no banco do carona, não importa quem seja o motorista (ou mesmo que não exista um), o que implica em uma representação de mulher não só como interesseira, mas principalmente

10. Cabana Blog. Pablo Cabana. Disponível em: <http://www.cabanacriacao.com/blog/archives/ conar-fiat-stilo-black-motion/>. Acesso em: 14 abr. 2012.

11. Conferir, por exemplo, Propaganda sustentável. Jacques Meir. Disponível em: <http://www. propagandasustentavel.com.br/site/show.asp?post_id=166>. Acesso em: 14 abr. 2012. 
como submissa ao poder do homem. Nesse contexto, se os homens estão em patamares diferentes de poder, o que é indicado pelo carro que ele ocupa, à mulher cabe se submeter a eles para tirar proveito de suas posses.

No entanto, o debate na internet dividiu opiniōes: nem todos viram na peça um problema ético ou concordaram que ela ultrapassa o limite ético. Nas postagens percebem-se claramente os sentidos que, pelo efeito da ideologia, permaneceram naturalizados ao longo da história, mas, no conjunto, prevaleceram as vozes que questionam esses valores, estabelecendo confrontos.

A propaganda impressa, veiculada em um dos números da revista Época em $2009^{12}$, ocupa a metade inferior de duas páginas e repete o mote "Para poucos e maus", mas seu apelo, embora se construa a partir do sentido de paixão, não é às relaçôes interesseiras de "conquista", e sim à transgressão no trânsito.

$\mathrm{Na}$ meia página à esquerda, encontra-se uma foto que flagra um momento na noite, na qual aparecem dois carros pretos, um em primeiro plano e o outro em segundo. À direita, encontram-se os dizeres verbais, assim como dois detalhes em forma de seta, da direita para a esquerda, nos quais se evidenciam "itens de série". Em todo o anúncio prevalece a cor preta. Contrasta com ela o vermelho da lanterna do carro em primeiro plano e da marca do outro carro, assim como das setas que evidenciam os itens de série, de parte do nome do carro que compóe a mensagem verbal e ainda da logomarca; o branco dos dizeres verbais; o metálico dos faróis e da calota do carro em segundo plano.

$\mathrm{Na}$ imagem, uma luz metálica de um farol ao fundo, parcialmente projetado contra o carro que se encontra em segundo plano, também com os faróis ligados, sugere um choque iminente com o carro que está em primeiro plano.

Já o texto verbal é curto, porém, aliado às imagens, tem grande capacidade sugestiva. $\mathrm{O}$ sentido de transgressão configurado no exórdio e na imagem é reiterado diversas vezes, num jogo interessante do ponto de vista dos mecanismos linguísticos que mobiliza:

12. Época, n. 569, 13 de abril de 2009, p. 20-21. A análise aqui proposta retoma aquela realizada em Saleh; Saleh; Ferreira (2012). O anúncio pode ser visto na página 193 do referido artigo, disponível em <http://www.revistas2.uepg.br/index.php/conexao/article/viewFile/4550/3094>. 
Ainda bem que não existe multa por excesso de itens de série.

É possível recuperar latente a esse enunciado a expressão "multa por excesso de velocidade", advinda do discurso legal sobre o trânsito. A substituição do termo "velocidade" por "itens de série" desloca o sentido estabilizado da expressão nesse discurso, possibilitando a criação de um novo sentido que, no entanto, se constrói sobre aquele que é subvertido, reforçando-o. Ou seja, o efeito de sentido promovido pela expressão "multa por excesso de itens de série" depende do reconhecimento, pelo interlocutor, da latência da expressão cristalizada "multa por excesso de velocidade", evidenciando, assim, um movimento no eixo metafórico da linguagem, tal como o entende Lemos (LEMOS [1992] 1998), retomando Jakobson em sua releitura de Saussure.

Além dessa substituição, dois outros processos linguísticos são mobilizados no exórdio. Ele é introduzido pela expressão "ainda bem" que, nos termos de Ducrot (1987), apresenta dois pontos de vista divergentes, dois enunciadores, marcando a opçáo do falante/locutor por um deles, que será aquele apresentado no enunciado que a locução introduz. Segue-se a este processo aquele implicado pela presença do advérbio "não" que igualmente pressupóe um contra-enunciado afirmativo. Dessa forma, subjacente a este enunciado, é possível reconhecer outro:

Ainda bem que não existe multa por excesso de itens de série.

Que pena que existe multa por excesso de velocidade.

Assim, para levar o seu interlocutor, marcadamente um leitor jovem, a se identificar com o carro, enfatizam-se os itens de série, mas procurase valorizar essa pretensa vantagem do modelo atrelando implicitamente esses itens à capacidade que eles têm de potencializar o comportamento transgressor na direçáo.

É de se notar que a eleição do público jovem está marcada já na opção de criação de um modelo esportivo que só seria distribuído na cor preta, o que o próprio nome do modelo Novo Stilo Black Motion antecipa. Nele, alia-se a referência ao preto (Black) à ideia de movimento (Motion), optando-se pela denominação em inglês. Em relação a este aspecto, por 
um lado, joga-se com a estratégia de valorizar o interlocutor que é capaz de "ler" o nome do modelo, promovendo-se ainda identificaçáo com a cultura norte-americana, tão valorizada em nossa própria cultura; por outro, reforça-se a hierarquia entre os que são e os que não são capazes dessa leitura. A hierarquização é reafirmada de forma mais explícita na continuidade do texto: "Para poucos e maus". Assim, a sequência "Novo Stilo Black Motion. Para poucos e maus" será interpretada como "Black Motion. Estilo de poucos e maus”. A imagem - em que prevalece o preto, com uma luz metálica de um farol ao fundo, parcialmente projetado contra o carro em segundo plano, sugerindo um choque iminente com o carro em primeiro plano - é a expressão imagética do sentido construído na sequência verbal, ao mesmo tempo em que a potencializa.

Como cabe a um slogan, "Movidos pela paixão" - em branco, favorecendo o destaque da marca da Fiat, em que prevalece o vermelho em contraste com o metálico - é a metáfora do impulso, do irracional, reiterando o sentido de transgressão de "para poucos e maus", assim como o título implicitamente anuncia; joga com as cores vermelha e preta da imagem, configurando uma relação metafórica de significação, na qual a imagem significa a linguagem verbal e vice-versa. Promove-se, assim, uma transferência do sentido de paixão amorosa, culturalmente vinculada à cor vermelha, para o sentido de paixáo pela transgressáo, vinculada ao carro, reforçando-se a ideia de arrebatamento e de irracionalidade e, ao mesmo tempo, projetando tais características como um traço da identidade do jovem.

Nesta versão impressa não aparece uma personagem feminina, mas será que a mulher não estaria ali representada? Embora a mulher não apareça explicitamente na peça, sua imagem está ali implicada. Sendo o carro um item de consumo que simboliza prestígio e poder e que historicamente diz respeito ao homem, à mulher cabe a posição de "carona", seja no momento de escolher o carro, seja no momento de utilizá-lo. Essa representação de gênero - masculino e feminino - é condizente com as posiçôes sociais do homem e da mulher na nossa sociedade, na qual ainda cabe à mulher uma posição subalterna nas relaçóes de poder tanto no âmbito público como privado.

O interlocutor preferencial nessa peça é o homem jovem, mas seja o interlocutor representado como um executivo, como um bad boy, ou como um amante de aventuras radicais em lugares inóspitos, ele ainda tem sido 
representado nos comerciais de carro como detentor do poder de compra e de escolha, inclusive da mulher, como definidor de comportamentos em relação a esse item de consumo. Nesse contexto, é comum a mulher identificar o carro como um item que diz respeito privilegiadamente ao universo masculino, ao qual ela só pode ter acesso a partir da mediação masculina, efeito da ideologia que vincula o poder ao homem.

$\mathrm{E}$ as estatísticas mais uma vez confirmam que o discurso não está dissociado da "realidade", ou melhor, que a realidade é moldada pelos discursos: dados colhidos em sites diversos dáo conta de que no Brasil a cada 10 motoristas, 7 são homens e 3 são mulheres, aproximadamente.

Nesse sentido, vale notar que são bastante recorrentes anúncios de carros não populares, especialmente no caso de sedans, nos quais o único personagem é o carro. Poderíamos então imaginar que nesse caso não há uma projeção de identidade. No entanto, quando consideramos que o predomínio da cor prata e de outros elementos que criam uma atmosfera de sobriedade e objetividade, tanto da imagem como na forma de apresentação dos dados, nos damos conta de que se trata de uma configuração cujo efeito de sentido imaginariamente remete ao universo masculino.

Embora, como lembrei acima, na segunda seção deste trabalho, diversos fatos e análises indiquem que a distribuição de poder entre homens e mulheres na nossa sociedade tem modificado em direção a uma posição mais equitativa, ela ainda se encontra longe do equilíbrio. As representaçôes de gênero nos anúncios de carros, assim como as estatísticas que procuram mapear a situação dos salários, dos motoristas e das horas trabalhadas com e sem remuneração são alguns desses fatos e análises, os quais nos permitem entender que de fato os conceitos de homem e mulher são construçóes discursivas articuladas entre si. Não se trata simplesmente de uma oposição, mas de uma hierarquia que está na base do pensamento e do conhecimento moderno, na qual, como vimos, o sujeito é estruturalmente masculino.

\section{Considerações finais}

Os PCN e outros documentos oficiais enfatizam a necessidade de a escola propiciar condiçóes para o desenvolvimento da cidadania. O exercício de uma visão crítica em relação às representações de identidades sociais 
na publicidade é uma das condiçóes para se exercer a cidadania. Faz-se necessário o desenvolvimento da capacidade de analisar de forma crítica a publicidade, de forma a possibilitar o questionamento dos valores que ela veicula e, portanto, que se assuma uma posição ética em relação a eles. Embora uma das características do discurso publicitário seja mobilizar ideologias já existentes na sociedade, uma questão que se coloca de forma muito aguda para essa prática é, como vimos, o limite ético. Uma questão central é o entendimento que as pessoas possuem acerca do funcionamento das peças publicitárias e dos sentidos que elas produzem, os quais são historicamente situados e, portanto, necessariamente relacionados ao tempo e ao espaço em que circulam.

Com isso, será possível levar o aluno a identificar os sentidos explícitos e recuperar os sentidos implícitos veiculados no discurso publicitário, os quais foram historicamente naturalizados pelo funcionamento da ideologia. Assim, possibilita-se o questionamento dos valores que a publicidade veladamente acentua e perpetua em nossa sociedade, mesmo quando não sáo tematizados explicitamente, ou principalmente por isso, como é o caso da relação de gênero nas peças acima analisadas.

Considerando que, da perspectiva discursiva, a consciência não precede a experiência, mas se constitui a partir dela (ORLANDI, 2012), é necessário que as propostas educacionais saibam "'ouvir' e instaurar outros discursos que atravessem o discurso dominante", possibilitando que eles sejam "ouvidos e investidos na realidade histórica e social contemporânea, de tal modo que, essas outras experiências encontrem voz e possam (re) significar (se) ${ }^{13}$ " (ORLANDI, 2012, p. 168) na nossa sociedade. Trata-se de uma condição necessária para o aprimoramento do respeito à diferença e para o desenvolvimento de valores mais solidários e, portanto, da consciência ética das nossas crianças e adolescentes, não só em relação às posiçóes de gênero, mas também de outros aspectos identitários, tais como raça/etnia, nacionalidade, sexualidade, religião, etc.

13. Essa reflexão da autora se dá no contexto de uma discussão sobre a Educação para os Direitos Humanos, mas ela nos parece muito pertinente também para se pensar o estatuto da educação para a diversidade. 


\section{REFERÊNCIAS}

BAKHTIN, M. Estética da criaçáo verbal. 4. ed. São Paulo: Martins Fontes, 2003.

BONFANTI, C. No Rio, 22\% dos trabalhadores demoram mais de uma hora para chegar ao emprego, diz OIT. O Globo/Economia. Disponível em: <http://oglobo.globo.com/economia/ no-rio-22-dos-trabalhadores-demoram-mais-de-uma-hora-para-chegar-ao-emprego-diz-oit5520298\#ixzz216OLjC8P>. Acesso em: 19 jul. 2012.

BRASIL. Secretaria de Educação Fundamental. Parâmetros Curriculares Nacionais: terceiro e quarto ciclos: apresentação dos temas transversais. Brasília, DF, 1998.

CABANA, P. Conar susta a veiculaçáo do comercial do Fiat Stilo Black Motion. Disponível em: <http://www.cabanacriacao.com/blog/archives/conar-fiat-stilo-black-motion/>. Acesso em: 14 abr. 2012.

CAROZZA, N. G. V. Publicidade: o consumo e sua língua. 2010. 157 f. Tese (Doutorado em Lingüística), IEL, Unicamp, Campinas, 2010.

DUCROT, O. Esboço de uma teoria polifônica da enunciação. In: O dizer e o dito. São Paulo: Pontes, 1987. p. 161-218.

HALL, S. A identidade cultural na pós-modernidade. Tradução Tomaz Tadeu da Silva, Guacira Lopes Louro. 10. ed. Rio de Janeiro, DP\&A, 2005.

KURZ, R. Tabula rasa. 2003. Disponível em: <http://antivalor.atspace.com/Exit/kurz309. htm>. Acesso em: 02 abr. 2012.

LEMOS, C. T. G. Os processos metafóricos e metonímicos como mecanismos de mudança. Substractum: temas fundamentais em psicologia e educação, Porto Alegre, v. 1, n. 3, p. 151172; trad. Ernani Rosa. [1992] 1998.

MEIR, J. Propaganda sustentável. Disponível em: <http://www.propagandasustentavel.com. br/site/show.asp?post_id=166>. Acesso em: 14 abr. 2012.

ORLANDI, E. P. Discurso em análise: sujeito, sentido e ideologia. Campinas: Pontes, 2012.

Interpretaçáo, autoria, leitura e efeitos do trabalho simbólico. Petrópolis: Vozes, 1996.

PÊCHEUX, M. Semântica e discurso: uma crítica à afirmação do óbvio. 2. ed. Campinas: Editora da UNICAMP, 1995.

Discurso: estrutura ou acontecimento? 5. ed. Campinas: Pontes, 2005.

SALEH, A. M.; SALEH, P. B. O. Apresentação didática do projeto "Educação para o consumo responsável”. Revista Conexão UEPG, Ponta Grossa, PR, v.1, n.6, p. 28-33, 2010. Disponível em: <http://www.uepg.br/revistaconexao/revista/edicao06/4.pdf>. Acesso em: 14 abr. 2012. 
SALEH, A. M.; SALEH, P. B. O. Consumo Responsável: um passo além do aspecto ambiental. Educar em Revista, Curitiba, n. 44, p. 167-179, abr./jun. 2012.

SALEH, P. B. O.; SALEH, A. M.; FERREIRA, A. de J. Educação para o consumo e para a diversidade: representaçôes de gênero em anúncios publicitários. Revista Conexáo UEPG, v. 8, n. 2, p. 188-197, 2012. Disponível em: <http://www.revistas2.uepg.br/index.php/conexao/ article/viewFile/4550/3094>. Acesso em: 20 jun. 2013.

SEFFNER, F. Gênero, sexualidade, violência e poder. In: Educaçáo para igualdade de gênero. Salto para o futuro, ano XVIII, Boletim 26, p. 15-19, nov. 2008. Disponível em: <http:// tvbrasil.org.br/fotos/salto/series/163222Edu_igualdade_gen.pdf>. Acesso em: 02 abr. 2012. 


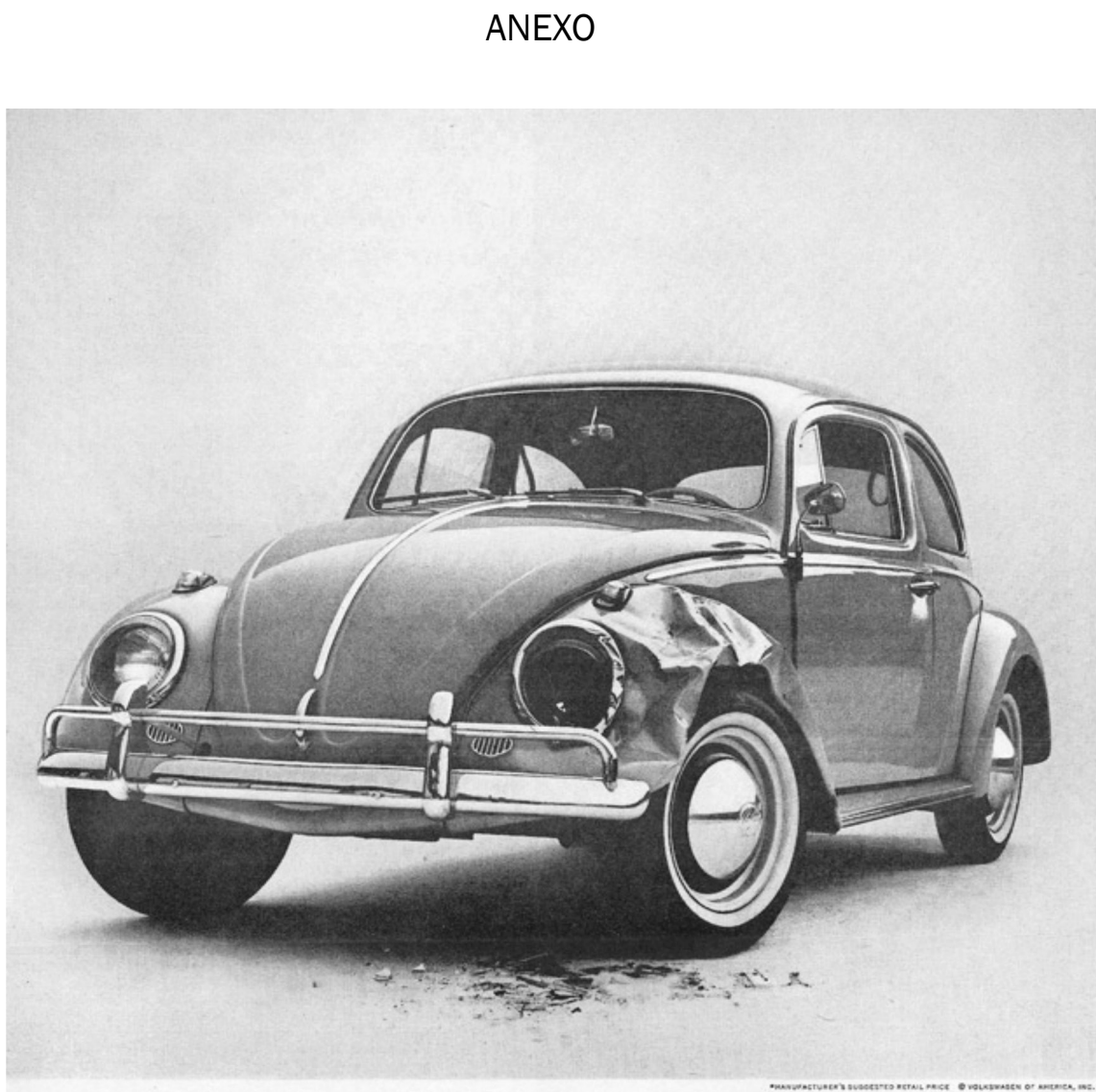

\section{Sooner or later, your wife will drive home one of the best reasons for owning a Volkswagen.}

Women are soft and gentle, but they hit things.

If your wife hits something in a Volks. wagen, it doesn"t hurt you very much.

VW parts are easy to replace. And cheap. A fender comes off without dis. mantling half the car. A new one goes on with just ten bolts. For 324.95 ; plus labor.
And a VW dealer always has the kind of fender you need. Because that's the one kind he has.

Most other VW parts are interchange. able too. Inside and out. Which meons your wife isn't limited to fender smoshing.

She can jab the hood. Graze the door. Or bump off the bumper.
It may make you furious, but it won't make you poor.

So when your wife goes window-shopping in a Volkswagen, don't worry.

You can conveniently replace onything she uses to stop the car.

Even the brakes.

Fonte: <http://ideagenda.posterous.com/sooner-or-later-your-wife-will-drive-home-one>. Acesso em: 02 abr. 2012. 


\title{
A (DES) CONSTRUÇÃO DA IDENTIDADE FEMININA EM A HORA DA ESTRELA
}

\author{
Marly Catarina Soares \\ Universidade Estadual de Ponta Grossa
}

A discussão sobre identidade se tornou um desafio desde que a percepção de sujeito não é mais entendida como algo acabado, centrado, definido, sem mudanças. A desconstrução dos conceitos essencialistas de sujeito, de identidade, tem a ver com a noção de um problema que nos afeta diretamente: o problema da diferença. Hall (2000) afirma que no contexto da crítica antiessencialista das concepçóes étnicas, raciais e nacionais de identidade cultural e da política da localização surgiram concepçóes teóricas das mais imaginativas e radicais sobre subjetividade e identidade. Se esta noção está bem compreendida, imediatamente há que aceitar que os conceitos que partem da ideia de homogeneidade não nos servem mais.

Vivemos num mundo em que não cabem mais as generalizações e sim o reconhecimento das diferenças de gênero, diferenças de sexo, diferenças culturais e entre culturas, e todos os tipos de diferenças possíveis. Para Hall, (2000) a crítica desconstrutivista colocou alguns conceitoschave "sob rasura", pois "não servem mais, não são bons para pensar - em sua forma original não reconstruída” (p. 104). Se por um lado esses conceitos que vêm de uma crítica essencialista estão com seu prazo de validade vencido, por outro lado ainda não existem conceitos que possam substituí-los. Assim, Hall diz que tais conceitos continuam lidos, mas sob nova perspectiva, como forma de questionamento, buscando outras formas de 
entendimento a partir de uma nova realidade que se apresenta. No centro dessa discussão desconstrutivista está o conceito de identidade, que para Hall opera também "sob rasura", "no intervalo entre a inversão e a emergência: uma ideia que não pode ser pensada de forma antiga, mas sem a qual certas questóes-chave não podem ser sequer pensadas" (p. 104).

No centro dessas discussóes está a questão da identidade feminina, que veio para provocar ainda mais a confusáo promovida pelos estruturalistas, pós-estrutralistas, desconstrutivistas e antiessencialistas. É a partir dos estudos sobre a identidade na pós-modernidade que vou analisar as personagens femininas do romance A Hora da Estrela e do filme homônimo de Suzana Amaral.

No ano de 1977, pouco antes de morrer, Clarice presenteia seus leitores com a publicação do romance $A$ Hora da Estrela, que conta a história de uma moça nordestina, retirante, sem família e que veio buscar, na cidade grande, condiçóes de sobrevivência, ou pelo menos a intençáo primeira era essa. Todo o desenrolar do enredo tem como centro a personagem Macabéa e o narrador Rodrigo S.M., que se coloca como o mais importante dos sete que aparecem na história: "A história - determino com falso livre-arbítrio - vai ter uns sete personagens e eu sou um dos mais importantes deles, é claro" (LISPECTOR, 1998, p. 13). A história de um está intimamente ligada a história do outro. $\mathrm{O}$ narrador insere a personagem Macabéa na história sutilmente: “[...] é que numa rua do Rio de Janeiro peguei no ar de relance o sentimento de perdição no rosto de uma moça nordestina." (LISPECTOR, 1998, p. 12). Rodrigo não dá detalhe nenhum da personagem, nem seu nome, nem características físicas, apenas lança a imagem de uma moça qualquer andando na rua sem rosto, sem identidade, sem identificação. $O$ único fato que os liga de imediato é que o narrador também nasceu no Nordeste. Há uma espécie de aproximação identitária entre os dois que não se apaga mesmo após a migração.

Stuart Hall aponta que as discussóes sobre identidade se vinculam aos processos de globalizaçáo que coincidem com a modernidade e os processos de migração forçada ou livre (HALL, 2000, p. 108). Para o autor, "as identidades parecem invocar uma origem que residiria em um passado histórico com o qual elas continuariam a manter certa correspondência" (HALL, 2000, p.108). Hall ressalta ainda que as identidades são construídas dentro do discurso, que devem ser compreendidas como são produzidas, em locais históricos e institucionais específicos, no interior de 
formações e práticas discursivas, por estratégias e iniciativas específicas. Ele acredita que a apropriação que faz do termo identidade em seus mais recentes trabalhos pode não ser compreendida por outras pessoas. $\mathrm{O}$ termo identidade significa, por um lado, o ponto de encontro entre os discursos e as práticas que tentam interpelar, falar ou convocar para que se assumam lugares como sujeitos sociais de discursos particulares e, por outro, os processos que produzem subjetividades, que constroem como sujeitos aos quais se pode falar. As identidades são as posiçôes que o sujeito é obrigado a assumir embora "sabendo", sempre, que elas são representaçóes, que a representação é sempre construída ao longo de uma "falta", a partir do lugar do Outro e que, assim, elas nunca podem ser ajustadas - idênticas - aos processos de sujeito que são nelas investidos (HALL, 2000).

Os dois, narrador e personagem, por um motivo ou outro tiveram de sair de sua terra, o Nordeste, mas trouxeram na bagagem a história, a linguagem e a cultura, pois, segundo Hall, a utilização desses recursos produz aquilo que nos tornamos. Mas afinal, quem é Macabéa? Nada dela sabemos, nem o nome, que é uma das formas de identificação da pessoa, apenas o fato de ser nordestina: "Mas a pessoa de quem falarei mal tem corpo para vender, ninguém a quer, ela é virgem e inócua, não faz falta a ninguém" (LISPECTOR, 1998, p. 13). Retornamos então àquela primeira imagem captada numa rua qualquer do Rio de Janeiro de uma moça sem rosto, sem nome, sem identidade.

A constituição da identidade a partir das formulaçôes vistas no parágrafo anterior está atrelada a construção de sujeito, constituído não só pelo discurso como pelas posiçóes que assume e ainda mediante uma exclusão e diferenciação. Hall apresenta o argumento de Judith Butler de que o sujeito é discursivamente construído e não existe qualquer sujeito antes ou fora da Lei: todas as identidades funcionam por meio da exclusão, por meio da construção discursiva de um exterior constitutivo e da produção de sujeitos abjetos e marginalizados, aparentemente fora do campo do simbólico, do representável, o qual retorna, então, para complicar e desestabilizar aquelas "foraclusóes" que são chamadas de identidades. Este posicionamento se justifica em relação à sexualização e à racialização do sujeito (HALL, 2000) e o que Spivak (1994) chama de sujeitos subalternos.

Judith Butler (2000) aponta que a formação de um sujeito exige uma identificação com o fantasma normativo do sexo. Presume-se que Macabéa é do sexo feminino, pois ela assume os significados sociais impostos para 
o gênero feminino, embora não haja, pela descrição do narrador, qualquer indício de feminilidade. Do primeiro vislumbre anônimo que o narrador apresenta, o leitor entende que se trata de alguém do gênero feminino: pelas marcas pronominais - ela - e pelos substantivos - a jovem, a moça nordestina.

O narrador começa a esboçar o perfil da personagem, construindo-a a par e passo ao longo do romance, embora relutantemente, pois as características físicas vão surgindo como um traçado numa folha de papel, diga-se de passagem, linhas estas mal traçadas, pois não há um formato que a embeleze, muito pelo contrário, é o desconcerto, o grotesco que predomina. Aos poucos, descobrimos que ela nasceu em Alagoas, tem dezenove anos e completou até o terceiro ano do primário. Embora quase analfabeta, conseguiu um emprego de datilógrafa, o que lhe deu alguma dignidade. Corpo minguado, descarnado, chamá-la de feia seria um adjetivo que a qualificaria num determinado critério, o que não é o caso. $\mathrm{A}$ nulidade do ser mesmo em formação está aquém de um ser em gestação no ventre materno, pois este pode ser conhecido desde os primeiros meses de gestação e passa por um processo de identificação, pois recebe um nome.

Para nossa personagem não cabe nem o direito de "ser", pois não lhe é dado o direito de se saber quem é: "Quero antes afiançar que essa moça não se conhece senão através de ir vivendo à toa. Se tivesse a tolice de se perguntar 'quem sou eu' cairia estatelada [...] É que 'quem sou eu?' provoca necessidade. [...] Quem se indaga é incompleto.” (p. 15).

A primeira noção do estar no mundo, de sujeito e de se sentir sujeito é o questionamento que se faz: "quem sou eu?". A moça parece não ter a capacidade de se pensar, seu físico é mal construído, seu exterior pode ser visto, mas parece não haver interioridade, não há qualquer consciência de "eu”, pois ela não se pensa. É um ser desabilitado para viver, embora o narrador situe a personagem num espaço e num determinado tempo, dandolhe uma certificação de nascimento, pois nasceu no sertão de Alagoas e foi criada por uma tia, mora na Rua do Acre e trabalha num escritório na Rua do Lavradio. Percebe-se que a personagem Macabéa não é um sujeito desconstruído, pois para desconstruir algo é necessário que tenha havido uma construção. O que ocorre é a falta, o vazio, o nada, não há uma construção de sujeito e de identidade: ela é somente uma pessoa física, que "vive num limbo pessoal", "vive inspirando e expirando", "o seu viver é ralo", "incompetente para a vida". 
A partir dos estudos de Foucault sobre o sujeito que se constrói por suas práticas discursivas, entende-se que não há um abandono ou abolição do sujeito, mas sim sua reconceptualização. Para Hall (2000), é preciso que se pense o sujeito em sua nova posição - deslocada ou descentrada no interior do paradigma. Essa relação entre sujeitos e práticas discursivas dá margem à discussão da questão da identidade ou no caso de uma subjetivação dela: a identificação. Hall (2000) entende que a identificação, sob o ponto de vista da abordagem discursiva, é vista como processo em construção nunca completado - nunca é completamente determinada, no sentido de que se pode ganhá-la ou perdê-la, ou ainda no sentido que pode ser sustentada ou abandonada. Ao longo da narrativa, Rodrigo, o narrador do romance, vai revelando alguns traços de identificação de Macabéa, como se fosse uma moldagem. Os primeiros traços se referem à identificaçáo física de Macabéa: é uma moça nordestina, que veio para o Rio de Janeiro, arrumou emprego de datilógrafa apesar de ser quase analfabeta, gostava de tomar café frio antes de dormir, "a sua cara é estreita e amarela como se ela já tivesse morrido", tinha ombros curvos, dormia de combinação, de dia usava saia e blusa; ela toda era um pouco encardida, seu cheiro era morrinhento. Nem sabia mais se um dia teve pai e mãe, fora criada por uma tia. Nascera raquítica por força dos maus antecedentes herança do sertão.

A trajetória de Macabéa nos é mostrada por meio do olhar do narrador Rodrigo S.M., que se isola em seu apartamento para entrar no mundo da personagem que criou, fato que ele nega: "eu não inventei essa moça; ela forçou dentro de mim sua existência” (p. 19). Percebese que a não existência de qualquer indício de humanidade dela afeta diretamente o narrador, pois ocorre a desconstruçáo de sua identidade no sentido de igualar-se a ela, o que o faz transformar-se fisicamente e psicologicamente:

Por enquanto quero andar nu ou em farrapos, quero experimentar pelo menos uma vez a falta de gosto que dizem ter a hóstia [...] para falar da moça tenho que não fazer a barba durante dias e adquiri olheiras escuras por dormir pouco, só cochilar de pura exaustão, sou um trabalhador manual. Além de vestir-me com roupa velha rasgada. Tudo isso para me colocar no nível da nordestina. (LISPECTOR, 1998, p. 19). 
O mundo de Macabéa, da mesma forma que ela, vai se moldando, e todos que a rodeiam parecem ter mais humanidade do que ela própria. Poderíamos dizer que numa escala classificatória de subjetivação, ela seria a que é destituída de qualquer indício de subjetividade, enfim ela não é um sujeito. Se considerarmos que o sujeito se constrói pela discursividade, Macabéa é qualquer coisa menos sujeito, pois não é capaz de produzir um discurso significativo nem para ela mesma: "ela era calada (por não ter o que dizer) mas gostava de ruídos": "Maca jamais disse frases, em primeiro lugar por ser de parca palavra. E acontece que não tinha consciência de si e não reclamava nada, até pensava que era feliz”. (p. 69)

Em alguns raros momentos, Macabéa dá algum indício de saberse de si: quando mentiu a primeira vez para ficar em casa descansando. Aprendeu o valor da mentira e sua função social, pois a mentira "pegara", e mentir às vezes poderia ser parte de um protocolo social ou ainda índice de boa educação. O estar sozinha proporciona-lhe sentimentos indescritíveis como a sensação de liberdade e o valor da solidão: "Encontrar-se consigo própria era um bem que ela até então náo conhecia”. (p. 42). Ouvir o radinho tocando alto, saborear o café solúvel emprestado se lambendo em frente ao espelho e reconhecer-se nele. Outro momento significativo que se poderia chamar de flash de subjetivação ocorre após Olímpico ter acabado o namoro: ela comprou um batom vermelho e rebocou a boca numa fracassada tentativa de imitar a boca de Marilyn Monroe. No confronto com Glória aponta outro índice de identificação: "sou moça virgem", (p. 62) ao se defender da investida da colega.

Além de Macabéa, situada como a personagem mais importante da história, o narrador dá vida a quatro moças que dividem o quarto com a nordestina. Todas as quatro são balconistas das Lojas Americanas, cujos nomes são: Maria da Penha, Maria Aparecida, Maria José e apenas Maria. São personagens que, apesar de serem identificadas por um nome, são anônimas. Têm identidade, mas não nos é revelado o perfil físico, cor de cabelo ou os traços do rosto: são mulheres sem rosto e sem corpo. Sabemos que existem porque dividem um quarto minúsculo com Macabéa e convivem com os seus hábitos nada higiênicos. Algumas vezes o narrador faz uma rápida citação de cada uma delas com o objetivo único de contextualizar o mundo de Macabéa: o rádio de pilha foi uma delas quem lhe deu, o cheiro morrinhento dela que as Marias têm que suportar ou a tosse de Macabéa que elas não se incomodam. Não há qualquer tipo de relacionamento, 
vínculo de amizade ou coleguismo pelo fato de morarem juntas, mesmo que à noite se encontrem para dormir. Elas aparecem e desaparecem da narrativa sem qualquer prejuízo, pois não têm voz e nem vez. Sabemos que são moças simples, que trabalham nas Lojas Americanas e que não se incomodavam com a presença de Macabéa. Sempre cansadas "pelo trabalho que nem por ser anônimo era menos árduo." (p. 31).

No trabalho, que é o espaço em que Macabéa passa a maior parte do dia, é obrigada a dividi-lo com Glória, outra personagem feminina que somente ganha o direito a voz quando mantém interlocução com ela, entretanto o leitor só irá conhecê-la pelo olhar de Olímpico, o macho que reconhece na fêmea um excelente espécime para procriação: "Glória era bem alimentada. E isso fazia dela material de boa qualidade."; "[...] ele soube que Glória tinha mãe, pai e comida quente em hora certa”; "[...] Olímpico caiu em êxtase quando soube que o pai dela trabalhava em um açougue"; “[...] Pelos quadris adivinhava-se que seria boa parideira”. A paixão momentânea provocada pelos predicados físicos de Glória é o motivo para que ele terminasse o namoro com Macabéa. O que difere Glória de Macabéa é o fato de a primeira ser o oposto da segunda. Ela é sexuada, sabe conquistar e segurar um homem: "Glória era um estardalhaço de existir. E tudo devia ser porque Glória era gorda”. A gordura na mulher era sinônimo de exuberância, de sensualidade. Glória era um exemplar de femme fatale, pois sem titubear rouba o namorado da colega: "Olimpico é meu, mas na certa você arranja outro namorado. Eu digo que ele é meu porque foi o que minha cartomante me disse e eu náo quero desobedecer porque ela é médium e nunca erra” (p. 70). É outra personagem que não apresenta sinais de subjetivação, ela aparece na história mais como estereótipo, pois não conta nem com o suporte do narrador para tentar construí-la. O que sabemos de Glória são alguns pontos de identificação por meio do olhar de Olímpico dados pelo narrador. A construção da personagem Glória, pelo ponto de vista masculino, dá a dimensão de construção de sexo e gênero numa classificação binária - sexo feminino e do gênero feminino que tem desejo pelo masculino. A mulher é entendida não como oposto ao homem e sim como complemento sexual dele, a parceira, a amante, a parideira. Ela conhece todos os artifícios da sedução, sabe utilizar sexualmente o corpo para atrair o macho. Mas o jogo de sedução que ela utiliza náo a tira da condição de submissão, de subalternidade, uma vez que precisa do homem para suprir suas necessidades básicas de sobrevivência. 
A cartomante é introduzida na história por meio da sugestão de Glória à Macabéa para procurá-la. Assim, a conexão de Macabéa com o mundo se amplia - tia, Seu Raimundo, Glória e Olímpico. Mas essa conexão é falha porque não há uma interação ativa entre ela e os outros. Dona Carlota, a cartomante, é a personagem que mais se destaca das demais, pois ela é a única que tem voz, e desde seu aparecimento na história passa a narrar-se. Constrói-se como sujeito e a sua identidade pela narração das mudanças e transformaçóes pelas quais passou. Carlota assume a voz do narrador e através dela conhecemos sua história de vida, suas vitórias, seus fracassos, seus amores e profissão. A feminilidade, no sentido de uma identidade feminina, que não existe nas mulheres personagens do romance, se levanta de forma inquestionável em Dona Carlota. Ela encarna as concepçóes de gênero e sexo contemporaneamente discutidas pelos estudos de gênero, que não se apoia numa concepção binária "homem - mulher". Judith Buttler (2000), afirma que:

\footnotetext{
Se o gênero consiste dos significados sociais que o sexo assume, então o sexo não adquire significados sociais como propriedades aditivas, mas, ao invés disso, é substituído pelos significados sociais que adota; o sexo é abandonado no curso dessa assunção e o gênero emerge não como um termo em uma permanente relação de oposição ao sexo, mas como um termo que absorve e desloca o "sexo", a marca de sua substanciação plena no gênero ou aquilo que, do ponto de vista materialista, pode constituir uma plena dessubstanciação. (p. 156).
}

Ela possui a sabedoria, o conhecimento sobre a vida, sobre o mundo, sobre os homens, sobre relacionamento, sobre sexualidade, sobre os prazeres femininos. Por intermédio de Carlota, o mundo feminino se descortina em todas as suas facetas: a mulher explorada e que explora, as obrigaçóes que ela tem que cumprir, a submissão ao macho que a explora e a violenta. E é talvez a única que traça o destino de Macabéa, coisa que o próprio narrador não se sente capaz de fazer.

eu tinha um homem de quem eu gostava de verdade e que eu sustentava porque ele era fino e náo queria se gastar em trabalho nenhum. Ele era o meu luxo e eu ate apanhava dele. Quando ele me dava uma surra eu via 
que ele gostava de mim, eu gostava de apanhar. Com ele era amor, com os outros eu trabalhava. Depois que ele desapareceu, eu, para não sofrer, me divertia amando mulher. (p. 74).

O que se evidencia no romance é que todas as mulheres personagens não se encaixam nos padrôes determinados pela sociedade patriarcal. $\mathrm{Ne}$ nhuma cumpre o papel social que lhe é destinado, não casam, não constituem família, não têm voz, exceto a cartomante, que adquiriu o direito à voz porque é portadora do conhecimento, e em suas mãos está o futuro das outras personagens. Por um curto espaço de tempo, Macabéa sentiu-se alguém, viva, com direito a ser sujeito e a ser feliz.

Todas estas personagens transpostas ao cinema apresentam a mesma trajetória de vida que no romance, com algumas nuances diferentes. A composição e a caracterização das personagens seguem o roteiro traçado por Clarice Lispector. Ocorre no filme a materialização delas tal como poderíamos imaginá-las, parece que recém saíram do livro. Embora não possa contar com o recurso do narrador, que é a alma do livro, a diretora lança mão de recursos próprios do cinema para dar um tom ao filme que se aproximasse do livro.

A fotografia apresenta algumas paisagens interessantes de São Paulo, como, por exemplo, o zoológico, cenário do passeio de Macabéa e Olímpico, e o contato dos dois com a natureza, como se fossem parte dela. $\mathrm{O}$ quarto que Macabéa divide com as Marias materializa a sujeira, a falta de higiene, que a aproxima de um ser abjeto, próximo de um inseto desprezível. Todos os locais em que a personagem Macabéa transita, como seu quarto, o escritório e a sala da cartomante, são escurecidos, decadentes, deprimentes. A história do filme é ambientada em São Paulo, ao passo que no livro se passa na cidade do Rio de Janeiro. A fala das personagens, os diálogos e as palavras ditas são fiéis ao romance. Suzana Amaral optou por narrar a história de Macabéa focalizando-a em seu quarto, no escritório, com o patrão e a colega de trabalho, Glória, e nos passeios com Olímpico. O clímax ocorre na visita que ela faz à cartomante. A escolha das músicas, o som, os (poucos) efeitos especiais, todos estes elementos são bem orquestrados para que se produzisse um resultado final que agradasse ao público e principalmente àqueles que gostariam de assistir no cinema a obra tal qual se apresenta na literatura. Suzana não reinventa a história, adapta algumas cenas e diálogos, mas prefere manter-se fiel ao livro. 
Tanto o livro quanto o filme apresentam um determinado grupo de mulheres excluídas, cuja exclusão ocorre por forças das contingências ou pelo simples fato de serem mulheres. A identidade parece ser um luxo, coisa de rico, que ao pobre não é permitido se sentir alguém enquanto sujeito e que seja um componente de um todo, resultado da interlocução com o outro ou com o Mundo.

\section{REFERÊNCIAS}

AMARAL, S. A hora da estrela. Brasil, 1985. DVD (96 min.). son., Color.

BUTLER, J. Fundamentos contingentes: o feminismo e a questão do pós-modernismo; n.11, Cadernos Pagu, p.11-42, 1998.

. Corpos que pesam: sobre os limites discursivos do "sexo" In: LOURO, G. L. (Org.).

O corpo educado: pedagogias da sexualidade. Belo Horizonte: Autêntica, p. 151-172, 1999.

HALL, S. Quem precisa de identidade. In: SILVA, T. T. (Org). Identidade e diferença: a perspectiva dos estudos culturais. Petrópolis: Ed. Vozes, 2000. p.103-133.

LISPECTOR, C. A hora da estrela. Rio de Janeiro: Rocco, 1998.

RICHARDS, N. Feminismo e desconstrução: novos desafios críticos. In: Intervençóes críticas: arte, cultura, gênero e política. Trad. Romulo Monte Alto. Belo Horizonte: Ed. UFMG, 2002

SCOTT, J. Experiência. Trad. (espanhol) de Moisés Silva; n.13, La ventana, 2001.

SPIVAK, G. Quem reivindica a alteridade. In: HOLLANDA, H. B. Tendências e impasses: o feminismo como crítica da cultura. Rio de Janeiro: Rocco, 1994. 
PARTE 3

\section{SEXUALIDADE}




\title{
DISCURSO DO SUJEITO: \\ A HOMOSSEXUALIDADE EM TEXTOS JORNALÍSTICOS CONTEMPORÂNEOS
}

\author{
Alexandre Sebastião Ferrari Soares \\ Universidade Estadual do Oeste do Paraná/Cascavel
}

Este artigo surge de uma reflexão que venho fazendo desde $2006 \mathrm{em}$ relação aos discursos sobre a (homo)sexualidade que estáo circulando, nos últimos 20 anos, na imprensa nacional.

A partir da AIDS como acontecimento discursivo no início da década de 1980, os sujeitos homossexuais ${ }^{1}$ imersos em um silêncio constitutivo, em se tratando de imprensa de circulaçáo nacional, passam a ser discursivizados, quase de forma generalizada, pelos meios de comunicação, numa relação causal com o vírus da imunodeficiência adquirida.

Essa relação construída entre o sujeito homossexual e a AIDS, discursivizada pelos meios de comunicação, a saber, revista Veja e IstoÉ, sobretudo, ganha fôlego nos discursos médico, religioso e legal quando trata(va)m do homossexual como "doente", "pecador" e "criminoso", respectivamente.

Durante esses últimos vinte anos, ainda que aquela relação entre ser homossexual e portador do vírus não circule mais na imprensa (por motivos inclusive científicos), continua reverberando em outros discursos, sobretudo no religioso. Não mais numa relaçáo causal entre ser homossexual e ser portador do vírus HIV, mas enquanto um agente em potencial

1. Refiro-me, exclusivamente, à homossexualidade masculina. 
de doenças psicopatológicas, num reforço de sua "promiscuidade" e sexualidade "anormal".

Na perspectiva teórica a qual me filio, os sujeitos são seres simbólicos e históricos, tendo, portanto, necessidade dos sentidos para viverem. Além disso, os sentidos não estão na essência das palavras, na sua "literalidade". Para que a língua faça sentido é preciso que se inscreva na história. Não há discurso sem sujeito, nem sujeito sem ideologia, e esta para um analista de discurso não é ocultação, pelo contrário, ela está no funcionamento que faz parecerem evidentes os sentidos quando na realidade eles se constituem em intricados processos em que entram em jogo o sujeito, as condiçôes de produção, sua inscrição em diferentes formações discursivas e a interpretação (ORLANDI, 2010).

Aqui, portanto, apresento a construção de sujeitos homossexuais no imaginário de jornais e revistas ${ }^{2}$ num período de aproximadamente vinte anos. Esses sujeitos, no entanto, não são os homossexuais com os quais nos relacionamos no nosso dia a dia, mas construçóes feitas a partir de alguns filtros: a imprensa escrita de circulação nacional e o século XXI.

Em 2009, iniciei um projeto sobre a abordagem da homossexualidade na mídia entre os anos 2005 e 2010, com o propósito de montar uma "cenografia" sobre o tema no Brasil. Como já havia concluído uma pesquisa em 2006 sobre o mesmo tema em relação à segunda metade da década de 1980 (1985-1990), foi possível, durante o trabalho, além de compreender o lugar que o homossexual ocupa nas páginas impressas, comparar o que se dizia na mídia sobre a homossexualidade num intervalo de 20 anos.

Além de alguns deslocamentos sobre o que se dizia nesses meios de comunicação, a saber, os jornais Folha de São Paulo e $O$ Globo, e as revistas Veja, Istoé, Época, Caros Amigos e Piaui, eu apresentava também o que circulou nos meios de comunicação na década de 1980.

No entanto, nesta apresentação me concentro quase que exclusivamente nas práticas discursivas nos anos 2005-2010 3 .

2. Quando me refiro à mídia no decorrer deste artigo, estou necessariamente referindo-me aos discursos televisivos, à imprensa de grande circulação e ao acervo de informaçôes online dessas mesmas empresas jornalísticas.

3. Apresentei, no primeiro encontro do GTDIS, parte dessa mesma pesquisa, com ênfase nos deslocamentos entre as décadas de 1980 e 2000. 
Antes de iniciar a exposição deste trabalho, é preciso esclarecer que o meu ponto de vista teórico é o da análise de discurso francesa, sendo que os princípios que regem este ponto de vista sáo:

a) Não tratamos de indivíduos compreendidos como seres que têm uma existência particular no mundo. Quero dizer que o sujeito, nessa perspectiva, não é um ser humano individualizado, mas que deve ser considerado como um ser social. Ele deve ser compreendido a partir de um espaço coletivo. Para um analista de discurso, o histórico e o simbólico não se separam (ORLANDI, 2010);

b) Sujeito e sentido se constituem ao mesmo tempo. O sujeito se significa ao dar sentido;

c) Para que as palavras façam sentido é necessário que elas já façam sentido (ORLANDI, 1996) e estejam inscritas na história, pois cada tempo tem a sua maneira de nomear e interpretar o mundo. Este é um complexo processo de memória. Há dizeres já ditos e esquecidos que estão em nós e que fazem com que ao ouvirmos uma palavra, uma proposição, ela apareça fazendo um determinado sentido. A memória discursiva é constituída pelo esquecimento. Esquecemos quando os sentidos se constituíram em nós, mas eles nos aparecem como evidentes, como um sempre "já-lá”;

d) Vivemos em uma sociedade estruturada pela divisão e por relações de poder, portanto, os sentidos não são os mesmos para todos, ainda que pareçam ser. Nós, analistas do discurso, tratamos do político que se inscreve na língua.

Trago como exemplo de construção desse sujeito no imaginário da imprensa seis Sequências Discursivas (doravante SD) produzidas na segunda metade da década de 2000.

A primeira, publicada pela Revista Veja, em 12 de maio de 2010, matéria de capa: Ser jovem e gay - a vida sem dramas.

O conflito entre Formações Discursivas aparece, sobretudo, entre pais e filhos (aparentemente, entre geraçóes), ainda que o texto da revista suavize este embate. $\mathrm{O}$ homossexual, nessa matéria, não está em conflito com os seus desejos, com os seus amigos heterossexuais, com a escola ou com o mundo, ele é bem resolvido e isso basta para que ele seja encarado como normal e se sinta feliz.

Segundo a reportagem, os movimentos de afirmação e luta por direitos civis não são importantes e não foram a partir deles que se produziram 
deslocamentos. É como se essa geração aparecesse sem um passado. Ela, segundo a matéria, é chamada de "sem-bandeira" e "sem-passeata" (mas também é chamada de supermercado de estilos ou sem rótulos), como se os novos anos produzissem naturalmente, sem nenhum conflito, esses sentidos.

Não existe mais o lugar das organizações em defesa de direitos. Essa geraçáo náo luta por causa alguma. Até as novelas da Rede Globo têm alguma importância nessa transformação. Todos esses dados se pautam em pesquisas realizadas por institutos com algum reconhecimento (o discurso jornalístico, mesmo reconhecendo a sua parcialidade em certos casos, continua se produzindo como neutro e imparcial):

Os adolescentes e jovens brasileiros começam a vencer o arraigado preconceito contra os homossexuais, e nunca foi táo natural ser diferente quanto agora. É uma conquista da juventude que deveria servir de liçáo para muitos adultos. (ROGAR, 2010 - grifos meus).

A tensão é toda ela na relação entre pais e filhos, principalmente na figura paterna. Segundo a revista Veja, o amor materno logo "supera o preconceito". Além disso, essa aceitação define a saúde mental e emocional desse adolescente.

E a segunda SD, publicada pela revista Piaui edição 43, de abril de 2010: Como mudar de sexo - A vida, as angústias e as cirurgias que transexuais fazem com o doutor Eloísio Alexsandro num hospital público do Rio de Janeiro.

Pacientes amputados costumam ter a sensação de membro fantasma. Sentem sensaçóes, dor, e incômodo na parte amputada como se ela ainda existisse. Transexuais náo sentem dor fantasma. "Isso só comprova que, para ela, o pênis de fato náo fazia parte do corpo", explicou Alexsandro. Ele considerou a cirurgia de Linda um sucesso. (BECKER, 2010 - grifos meus).

O espaço reservado para o tema é outro. Não é preciso mais estar na editoria da Saúdel Ciência ou ainda nas páginas policiais para se falar em transexualidade. $\mathrm{O}$ transexual não é mais um pervertido que sai do país 
para realizar a "fantasia da troca de sexo", ou realizar uma amputação, aqui, o efeito é de um ajuste entre o corpo e a mente.

A amputação traria a possibilidade de sentir uma "dor fantasma". Não é o que acontece com as pacientes desse hospital. Há uma impropriedade de seu próprio sexo anatômico e um ajuste entre a identidade de gênero e o corpo. A França foi o primeiro país a tomar a decisão de desconsiderar a transexualidade como um transtorno mental, em 2010.

Ontem $\left(1^{\circ}\right.$ de dezembro de 2011), o jornal $O$ Globo publicou a notícia sobre a nova Resolução (n.1.181/11) do Ministério da Segurança da Argentina, que determina que as forças policiais deverão respeitar a identidade de gênero adotada por travestis e transexuais, que poderão usar o uniforme de acordo com sua percepção de gênero.

$\mathrm{Na}$ eminência de ocorrer, no dia 04 de maio de 2011, o julgamento pelo Supremo Tribunal Federal (STF) do reconhecimento da união estável entre casais do mesmo sexo como entidade familiar, um acontecimento discursivo, ou seja, o encontro de uma atualidade e uma memória e a possibilidade de um novo vir a ser (PÊCHEUX, 2002, p. 17), adiei a conclusão dessa pesquisa porque imaginava que essa discussão pudesse colocar na ordem do dia questóes fundamentais para se pensar o sentido da homossexualidade a partir de uma diversidade de textos, ou seja, de dispositivos de arquivo específico de um tema, de um acontecimento, de um itinerário (GUILHAUMOU; MALDIDIER, 1994).

Dentre os textos que circularam durante as sessóes que discutiram no Supremo Tribunal Federal, a uniáo estável entre pessoas do mesmo sexo, no dia 04 e 05 de maio de 2011, a Conferência Nacional dos Bispos do Brasil (CNBB), se manifestou por meio do seu advogado, uma vez que a $\mathrm{CNBB}$, assim como diversas entidades e juristas, recebeu o status de consultora ou amiga do tribunal.

Nove entidades se manifestaram, a maioria a favor dos processos. Durante sua fala, o advogado da $\mathrm{CNBB}$ afirmou que "pluralidade tem limite":

A pluralidade tem limites e tem por diversas razóes, porque na medida em que decidimos nos contratar socialmente em torno de uma Carta que estabelece e delimita direitos e deveres mútuos que permitem nossa convivência, sabemos que nos submetemos a algumas demandas. Não vejo nenhum tipo de risco de incorrer em atitude preconceituosa. Se 
a sociedade clama por outra soluçáo, que busque no parlamento. Uma lacuna constitucional nâo pode ser confundida com não encontrar na Constituição Federal aquilo que eu quero ouvir. (SANTOS, 2011 - grifos meus).

O "nós" dos discursos da CNBB sempre é excludente, quando se trata dos homossexuais, sobretudo quando se trata do estilo de vida dos homossexuais. Fala-se sempre em "nome da sociedade", desde que dela não façam parte os gays, as lésbicas, as travestis e os transexuais. A sociedade nesta Formação Discursiva não comporta tal diversidade.

Um dado importante na construção do sentido que se estabelece nesta FD é o que nos aponta SOUZA (1997) em relação à "moral cívica" que emerge dos discursos ao tornarem públicas as questôes ligadas à ordem do privado.

Segundo o autor, a questão da subjetividade está ligada à escolha da forma sujeito que irá elidir nas instâncias públicas. Isso seria um novo dispositivo de subjetivação no espaço público, já que nem tudo pode ser dito e nem qualquer um pode dizê-lo.

Por isso, a moral cívica toma um espaço bastante considerável nos discursos religiosos que compóem o corpus dessa pesquisa: "em nome da sociedade", "em nome da família”, "em nome da moral e dos bons costumes" e "em nome de Deus" são muito recorrentes nesses textos.

No entanto, ao afirmar que existe uma lacuna constitucional, a CNBB pode estar, de certa forma, reconhecendo uma falta nessa Constituição, já que o sentido nunca é literal. E se "lacuna", ainda que não possa "ser confundida com não encontrar na Constituição Federal aquilo que se queira ouvir”, ou seja, é uma falha ou, pelo menos, uma omissão.

A posição da $\mathrm{CNBB}$ é a posição oficial da Igreja Católica, no entanto, não é a única opinião nesta $\mathrm{FD}$, pois há divergências no interior dessa FD que produziram sentidos na mídia.

O frei Gilvander Moreira, padre mineiro da Ordem dos Carmelitas, deu a seguinte declaração quando convidado a falar sobre a decisão do STF:

\section{Como o senhor recebeu a decisáo do Supremo?}

Com alegria, pois é uma vitória dos movimentos e dos grupos que historicamente vêm lutando pelo direito à liberdade sexual homossexual. 
Nesse caso, o STF posicionou-se com justiça e equidade. A sociedade está em constante transformação, e esse grupo em questão existe e está no dia a dia vivendo e construindo suas relaçóes à margem da sociedade. Devido a isso, o Direito náo podia mais se esconder ou continuar negando esse direito a relaçóes homoafetivas. Foi um exemplo de coragem e cidadania. Tornou-se visível o invisível. Declara-se assim o início do fim da hegemonia da moral heterossexual. Abre caminho para a afirmaçáo, à luz do dia, das mais de $\mathbf{6 0}$ mil unióes estáveis entre homossexuais no Brasil, que até aqui pagavam um altíssimo preço pela sua orientaçáo sexual. (OTÁVIO, 2011- grifos meus).

"Alegria” já nos remeteria a outra FD em se tratando da posição da Igreja Católica, embora vitória dos movimentos sociais não contradiga aquela FD. Sabemos que existem inúmeras pastorais envolvidas com os movimentos sociais.

Entretanto, "direito à liberdade sexual homossexual" não caberia nesta FD, assim como também não caberia falar em "justiça” e em "igualdade", "coragem” ou "cidadania”, "afirmação", "hegemonia heterossexual”, "união estável”, "orientação sexual”, tão pouco falar em "homoafetividade”.

Em virtude dessas declarações, o frei, e não poderia ser de outra maneira, foi advertido.

A partir de que lugar fala o frei? Talvez eu pudesse afirmar que ele fala a partir do "princípio de que todos somos iguais", do "princípio de que temos os mesmos direitos" ou ainda que fala em nome dos movimentos de luta por liberdade, ainda que esse movimento possa produzir também o sentido de liberdade sexual, no entanto, poderia ser apenas o de liberdade.

Sem dúvida, há uma contradição entre o que determina a religiáo católica (escrevo católica porque foi a CNBB que se manifestou através de seu advogado) sobre a sexualidade homossexual e o que diz o frei sobre receber tal decisão do STF "com alegria". As duas declaraçóes, ainda que partam do interior da mesma Instituição, se opóem em relação ao lugar construído, nesse interior, para esse sujeito homossexual.

É possível perceber que, se pensarmos em alguns dos deslocamentos sobre o que se diz do sujeito homossexual nos meios de comunicação desta década, os aspectos que dizem respeito às lutas em torno dos direitos civis 
é quase sempre o que motivam as discussōes na imprensa. Há duas décadas, o assunto girava em torno da AIDS.

No entanto, o que provoca as discussóes em torno dos direitos civis é quase sempre o preconceito e a violência. Ou seja, ainda que se possa perceber um deslocamento (pensando a década de 1980) do lugar desse sujeito nos meios de comunicação - ele fala, responde e enfrenta - há algo que esse sujeito não possui: o direito à indiferença, ou seja, o direito de não ser "objeto" das discussões.

Mas as discussões sobre a homossexualidade não se concentram exclusivamente na afirmaçáo ou nas lutas por direitos. Encontramos discussões nos meios de comunicação sobre a homossexualidade e seu estilo de vida, como na década de 1980, sobre promiscuidade, falta de vergonha, anormalidade, etc.

À revista Época, em fevereiro de 2011, o deputado Jair Bolsonaro do Partido Progressista (PP-RJ), dá a seguinte declaração ao ser questionado sobre a criação da Frente Parlamentar pela Cidadania LGBT:

O primeiro passo para desgraçar um país é mexer na célula da família. Eles vão atacar agora o ensino fundamental com o "kit gay", que estimula o "homossexualismo" e a promiscuidade. Tem muito mais violência no país contra o professor do que contra homossexuais. Quando eles falam em agressóes, é em horário avançado, quando as pessoas que têm vergonha na cara estáo dormindo. A regra deles é a porrada e querem acusar nós, os normais, os héteros. (ÉPOCA, 2011- aspas da revista e grifos meus).

No discurso do deputado do PP-RJ, o principal argumento se faz a partir do que se cristalizou como sendo um modelo de família. Ainda, se-

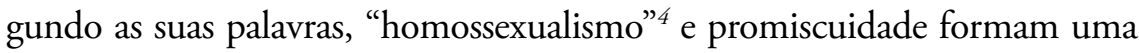
equação linguística ${ }^{5}$ impossível de se dissociar, um pensamento que circula e produz efeito.

4. Reproduzo a fala do deputado quando se refere à relaçáo entre pessoas do mesmo sexo: homossexualismo. É importante destacar que as razōes desse emprego são, em primeiro lugar, porque o deputado reproduz, ao usar essa denominação, o vocabulário do século XIX, que deu origem a uma certa ideia do 'homossexual'. E, também, pelo fato de que, na persistência de tais noçóes, percebe-se a manutençáo de costumes morais prisioneiros do sistema de denominaçáo preconceituosa que qualificam certos sujeitos como moralmente inferiores apenas pelo fato de apresentarem inclinaçóes eróticas por outros do mesmo sexo biológico. (SOARES, 2006).

5. Chamo de equaçáo linguística, locução cunhada por Mariani (1998: 18), para designar a equivalência de sentidos (no caso da homossexualidade, negativos) entre duas ou mais expressóes produzidas e recorrentes no interior de uma determinada formaçáo discursiva a partir de certas condições de produção de sentido. 
Uma possibilidade para se pensar onde circulam os meios de comunicação, a quem atingem e quais deslocamentos produzem. Bolsonaro está no seu sexto mandato e pauta a sua campanha nos princípios de "tradição" e "família".

Ele ainda organiza o seu discurso de modo que, ao citar as agressóes sofridas pelos professores, diminua a importância e a gravidade das ocorrências envolvendo homossexuais, além disso, apela para a simpatia dos seus eleitores, já que "defende" a Escola como instituição.

E ainda justifica essas agressóes em virtude do horário em que elas ocorrem. Primeiro como se elas ocorressem apenas na madrugada e depois como se o fato de acontecerem nesses horários fizesse com que pudessem ser mais bem digeridas ou isentas de responsabilidade.

Conclui seu pensamento reconstruindo outra equação linguística, a de que normalidade é igual à heterossexualidade em detrimento de outra que se inscreve no seu discurso: homossexualidade = anormalidade.

Todos esses sentidos já eram recorrentes na década de 1980 quando se falava sobre ser portador do vírus HIV justamente por desobediência aos preceitos religiosos, à moral e à normalidade.

Para rememorar, trago aqui uma carta do leitor publicada na revista Istoé em 1987:

Sobre a entrevista Sei que vou morrer, do paciente de AIDS M.R. (Istoé no 523): a natureza é drástica em sua puniçáo por ter sido violada tantas e tantas vezes, e que talvez seja a fórmula de chamar a atenção do homem para isso. O homem deve encontrar seu ponto de equilíbrio. Maria de Lourdes Ananias São Paulo - SP (ISTOÉ, 1987 - cartas dos leitores, grifos meus)

O maior dos deslocamentos que se pode perceber nos meios de comunicação em relação a duas décadas sobre a posição dos sujeitos homossexuais é, sem dúvida, as respostas imediatas sobre quaisquer manifestações contrárias aos seus direitos.

Nesta mesma edição da revista Época, de 21 de fevereiro, o deputado Jean Wyllys do Partido Socialismo e Liberdade (PSOL-RJ), dá a seguinte declaração: 
Bolsonaro é a caricatura de um deputado nostálgico de tempos sombrios de ditadura militar e repressáo às liberdades. Às vezes penso que nem ele acredita no que diz. É mais para produzir um efeito midiático e despertar o que há de pior nas pessoas para ter ganho eleitoral. Ele faz uso da ignorância popular e dos preconceitos que são reproduzidos e dos quais não se livram exatamente porque náo há um projeto sério que radicalize na defesa dos direitos humanos no país. (ARANHA, 2011, grifos meus).

O discurso do deputado do PSOL-RJ é uma forma de desqualificar o deputado do Partido Progressista, porque aproxima o que este deputado diz da época "sombria" da ditadura militar.

Nesse embate é incentivado o "homossexualismo" ou a heteronormatividade.

Nessa FD, o fato de ser contrário à homossexualidade sempre é atribuído à ignorância, à homofobia e ao preconceito.

Os efeitos tanto em numa quanto em outra FD nunca se efetivam como um embate que se dá exatamente quando há possibilidade de se expressar: os conflitos que fazem com que a sociedade funcione.

\section{ALGUMAS CONCLUSÕES:}

O espaço reservado para a homossexualidade migrou para outras editorias: Comportamento, Gente, Sociedade e Brasil. Na década de 1980, para falar de homossexualidade falava-se exclusivamente de AIDS, portanto as editorias eram, sobretudo, Ciência e Saúde.

O homossexual já não é exclusivamente homem como na década de 1980, agora há espaço na imprensa para a mulher homossexual, para a travesti (longe das páginas policiais), para os transgêneros (que ainda que não sejam homossexuais, são tratados nos meios de comunicaçáo como se fossem).

Fala-se da homossexualidade na terceira idade (sexo e maturidade era, praticamente, inexistente ou silenciado há duas décadas) e dos conflitos, oportunidades, desejos e práticas sexuais.

A partir de, pelo menos, quatro acontecimentos discursivos, o discurso sobre a homossexualidade começa a mudar na imprensa: 
a) O movimento organizado de afirmação e luta pelos direitos civis dos homossexuais que ressurge, no Brasil, na metade década de 1980 (primeiramente na luta contra a AIDS e depois pela afirmação da sexualidade também);

b) $\mathrm{O}$ fato de a homossexualidade deixar de ser considerada doença nos EUA em 1980 e em 1985 no Brasil;

c) A criação de políticas públicas, sobretudo nos 8 anos do governo Lula. Só para se ter uma ideia, o primeiro presidente a usar a palavra homossexual foi Fernando Henrique Cardoso.

d) Decisão no STF sobre a união estável entre parceiros do mesmo sexo.

Foram mais de 300 ocorrências ao longo desses 5 anos e meio de pesquisa nos meios de comunicação. Os assuntos mais abordados foram, por ordem de repercussão: a violência contra gays, lésbicas e travestis em Sáo Paulo e no Rio de Janeiro; assassinatos por ódio em todo o país; as agressôes ocorridas em SP, na USP e nas imediaçôes da Av. Paulista e da Rua Augusta; as lutas pela criminalização da homofobia e pelos direitos civis; a parada de orgulho gay e, finalmente, a repercussão das declaraçôes de deputados, artistas e jornalistas sobre diversos assuntos ligados a esse tema.

Cada uma dessas ocorrências, se pensarmos na abordagem sobre o homossexual nos meios de comunicação das duas últimas décadas, mesmo quando se fala em violência, preconceitos e homofobia, entre outros, apresenta um outro sujeito homossexual, aquela "cenografia” à qual me referi no início deste texto, trazendo a possibilidade de uma resposta imediata, porém não mais aquela que se ouvia há vinte anos (a reprodução de discursos médicos, religiosos e legais), mas quase sempre uma voz de afirmação.

\section{REFERÊNCIAS}

ARANHA, A. Frente gay no paredão do Congresso. Época, ed.666, p.52-53, fev. 2011.

BECKER, C. Como mudar de sexo. Piauí, n.43, abr. 2010. Disponível em: <http://revistapiaui. estadao.com.br/edicao-43/anais-da-medicina/como-mudar-de-sexo>.

FERNANDES, B. Terra magazine. São Paulo, 29 abr. 2011. Disponível em: <http:// terramagazine.terra.com.br/>. 
FOUCAULT, M. Verdade e poder. In : . Microffísica do poder. Rio de Janeiro, Ediçôes Graal, 2004.

MALDIDIER, D. ; GUILHAUMOU, J. ; ROBIN, R. Discours et archive. Liège: Mardaga, 1994.

MARIANI, B. O PCB e a imprensa: os comunistas no imaginário dos jornais 1922-1989. Rio de Janeiro: Revan, 1998.

ORLANDI, E. Interpretação: autoria, leitura e feitos do trabalho simbólico. Petrópolis: Vozes, 1996.

(Org.). Discurso e políticas públicas urbanas: a fabricação do consenso. Campinas, Editoras RG, 2010.

OTÁVIO, C. Padre contraria CNBB e elogia Supremo por legalizar união de casais gays no Brasil. Disponível em: <http://oglobo.globo.com/politica/padre-contraria-cnbbelogia-supremo-por-legalizar-uniao-de-casais-gays-no-brasil-2770237\#ixzz2d6T88pIO>. Acesso em: 15 mai. 2011.

PÊCHEUX, M. O discurso: estrutura ou acontecimento. 3.ed. Campinas: Pontes, 2002.

PRESSE, F. Transexuais poderão usar uniforme policial feminino na Argentina. Disponível em: <http://g1.globo.com/mundo/noticia/2011/12/argentina-transexuais-usarao-uniforme-napolicia-de-acordo-com-opcao-de-genero.html>. Acesso em: dezembro 2011.

ROGAR, S.; BORTOLOTI, M. A geração tolerância. Veja, ed.2164, p.106-114, 12 maio 2010.

SANTOS, D. Supremo adia decisão sobre união homossexual. Disponível em: <http://g1. globo.com/politica/noticia/2011/05/supremo-adia-decisao-sobre-uniao-homossexual.html>. Acesso em: 4 mai. 2011.

SOARES, A. S. F. A homossexualidade e a AIDS no imaginário de revistas semanais (19851990). 2006. Tese - (Doutorado) - Universidade Federal Fluminense, Rio de Janeiro, 2006.

SOUZA, P. Confidências da carne. Campinas: Editora da Unicamp, 1997. 


\title{
CAMPANHAS DE PREVENÇÃO CONTRA HIV/AIDS \\ ENTRE HOMOSSEXUAIS \\ E A GOVERNAMENTALIDADE DOS \\ CORPOS E DAS PRÁTICAS SEXUAIS NO DISCURSO MIDIÁTICO'
}

\author{
Jamil Cabral Sierra \\ Universidade Federal do Paraná/Setor Litoral
}

Campanhas publicitárias de combate e prevenção ao HIV/AIDS vêm ganhando espaço nos meios midiáticos nos últimos anos, ora com propósito de promover a conscientização/pedagogização sobre sexo, doenças sexualmente transmissíveis, prevenção e uso de camisinha (muitas vezes via discurso de amor, generosidade e respeito em relação às diferenças), ora tomando esses sujeitos como pessoas que também são, antes de qualquer outra coisa, consumidores, portanto indispensáveis à ordem neoliberal contemporânea. $\mathrm{O}$ fato é que o discurso de respeito às diferenças que passou a vigorar mais fortemente a partir da organização do movimento feminista, por volta dos anos sessenta (no Brasil), época que sugere nosso "ingresso" na pós-modernidade ${ }^{2}$, ou, para alguns, numa modernidade

1. Este texto é resultado de alguns excertos, revistos e modificados, de minha dissertação de mestrado, intitulada "Homossexuais, insubmissos e alteridades em transe: representaçốes da homocultura na mídia e a diferença no jogo dos dispositivos contemporâneos de normalização", defendida em agosto de 2004, no Programa de Pós-graduação em Letras, da Universidade Estadual de Maringá - UEM.

2. Por pós-modernidade estou entendendo um período de mudanças na concepçấo de sujeito e de identidade que, por convençôes cronológicas, começam a acontecer por volta da segunda metade do século XX, assinaladas especialmente pelo descentramento do sujeito cartesiano, de inspiração iluminista, descentramento este provocado pela releitura pós-estruturalista de Freud, Marx, Saussure, bem como pelas ideias em torno do poder defendidas por Foucault, que colaboraram, juntamente com o surgimento dos movimentos identitários, em especial o feminismo, para 
tardia, fez eclodir outros/novos movimentos sociais (e com eles, outros/ novos discursos) que, na emergência de reafirmar suas identidades, fragmentaram-se em diversos grupos, cada qual - de seu lugar e ao seu modo - constituindo, ou tentando constituir, uma política de identidade.

[...] cada movimento apelava para a identidade social de seus sustentadores. Assim, o feminismo apelava às mulheres, a política sexual aos gays e lésbicas, as lutas racistas aos negros, o movimento antibelicista aos pacifistas, e assim por diante. Isso constitui o nascimento histórico do que veio a ser conhecido como políticas de identidade - uma identidade para cada movimento. (HALL, 2001, p. 45).

A implementação dessas políticas fez ecoar os gritos de grupos que se arranjam coletivamente a partir de identidades culturais de gênero, raça, classe, sexualidade, etnia, que, historicamente silenciados, começaram a vazar pelas bordas, colocando em xeque o centro socialmente legitimado como normal. O escoamento da margem em direção ao centro de reivindicaçóes destes grupos de minorias (ou maiorias silenciadas, marginalizadas) fez surgir em cena uma política inscrita na pluralidade, que começa a questionar a centralidade imposta pela cultura do homem branco, ocidental, heterossexual e de classe média, bem como, a partir do deslocamento desta identidade padrão, interrogar a ideia de cultura, arte, estética e, como não podia deixar de ser, de verdade, concebida agora não como posta a priori, mas como uma construção sócio-historicamente discursivizada, cuja disseminação, na contemporaneidade $^{3}$, tem se dado, de modo muito especial, pelo discurso midiático ${ }^{4}$.

a emersão de outra(s) identidade(s), que assume(m), segundo Hall (2001), posiçóes diferentes em diferente situaçốes, modificando-se continuamente, mas não linearmente, em torno dos sistemas culturais que as rodeiam. Desse modo, a perspectiva da pós-modernidade marca um tempo de desestabilizaçáo, ruptura e deslocamentos dos discursos/narrativas modernas, como o pensamento dicotômico, a ideia de ordem e a noção de ciência que, desde o século XVI, começam a se firmar como verdade.

3. Quando falo em "contemporaneidade" o faço no sentido de marcar que não estou tomando este termo no sentido de um tempo marcado e isolado, bem como não estou imprimindo nesta expressão nenhuma marca que remeta a qualquer ideia de estabilidade, seguridade ou linearidade, uma vez que percebo a contemporaneidade como uma espécie de intercruzamento de tempos, como que um palimpsesto que, ao ser raspado, vai fazendo emergir as memórias discursivas de outros tempos e lugares.

4. No caso específico desse trabalho, pinço tais discursos especialmente da plataforma publicitária televisiva/impressa. De todo modo, isso não significa que as análises que trago aqui não se apliquem a outras plataformas midiáticas. 
E se elejo nesta problematização o discurso midiático, especialmente o veiculado pela plataforma televisiva/publicitária, como disseminadores dessas teias de ajustamento à ordem e à consciência burguesa, bem como se o que proponho é a leitura de textos que agregam sempre imagens de um outro, é porque o olhar que lanço ao discurso midiático me faz enxergá-lo como um dos principais mecanismos de dissipação pedagógica na contemporaneidade, ou seguindo as pegadas da formulação de Fischer (1997), porque o percebo como instrumento poderoso de disseminação/ inculcação pedagógica (tal como os discursos do Estado, da Igreja, Justiça, Família... e, claro, da Escola) que, ao propagar textos nos quais diferentes representações culturais são visualizadas/construídas, como a homossexual, faz suspeitar que as imagens contemporâneas da alteridade difundidas/ construídas como verdade por ela apenas recolocam, sob outros enfoques e estratégias, a mesma vontade de colonização da diferença, já que:

[...] poderíamos dizer que a mídia, em nossa época, estaria funcionando como um lugar privilegiado de superposição de "verdades", um lugar por excelência de produção, circulação e veiculação de enunciados de múltiplas fontes, sejam eles criados a partir de outras formaçóes, sejam eles gerados nos próprios meios. Uma das características principais é que, nela [na mídia], por razóes basicamente do alcance das tecnologias investidas nesse campo, qualquer discurso, materializado em entrevista de TV ou em cena de telenovela, por exemplo, é passível de ter sua força de efeito ampliada, de uma forma radicalmente diferente do que sucede a um discurso que opera através das páginas de um livro didático ou de um regulamento disciplinar escolar. (FISCHER, 1997, p. 65)

É por isso que Rosa Maria Bueno Fischer fala que há um “dispositivo pedagógico” na mídia, ou seja, que há um conjunto de práticas discursivas e também não discursivas pelas quais todos nós somos incitados, estimulados e, de certa maneira, obrigados a participar. Este dispositivo é gerado/ construído pela própria linguagem destes meios midiáticos - seja este meio um filme, outdoor, programa de TV ou uma propaganda - e trabalha na direção de promover sentidos e fabricar o olhar com o qual acostumamos a ver (e também a nos relacionar com) o mundo, os outros e a nós mesmos.

Em face disso é que quero, a partir dos acontecimentos que seguirão, questionar esses ditos pretensamente conciliatórios e humanitários 
(portanto inquestionáveis, de certo ponto de vista) de prevenção do corpo e uso da camisinha. Quero, neste texto, desconfiar de e deslocar essas narrativas sobre o corpo, tão evocadas e celebradas em nosso tempo, tentando mostrar como elas estão amarradas à heteronormatividade, à moral burguesa-cristã e às práticas de governamentalidade que intentam capturar e controlar os corpos e as práticas sexuais/afetivo-amorosas.

A noção de governamentalidade, usada aqui conforme análise feita por Foucault (2008a, 2008b), contribui sobremaneira para problematizar os modos pelos quais se constituiu no âmbito do estado moderno novos mecanismos de vigilância, controle e intervenção do Estado sobre a vida das populaçóes, fruto de novas estratégias entre o Estado, a economia política e os dispositivos de seguridade. Para Foucault, portanto, governamentalidade tem a ver com um

[...] conjunto constituído pelas instituições, os procedimentos, análises e reflexôes, os cálculos e as táticas que permitem exercer essa forma bem específica, embora muito complexa, de poder que tem por alvo principal a população, por principal forma de saber a economia política e por instrumento técnico essencial os dispositivos de segurança. Em segundo lugar, por 'governamentalidade' entendo a tendência, a linha de força que, em todo o Ocidente, náo parou de conduzir, e desde há muito, para a preeminência desse tipo de poder que podemos chamar de 'governo' sobre todos os outros - soberania, disciplina - e que trouxe, por um lado, o desenvolvimento de toda uma série de aparelhos específicos de governo [e, por outro lado], o desenvolvimento de toda uma série de saberes. Enfim, por 'governamentalidade', creio que se deveria entender o processo, ou antes, o resultado do processo pelo qual o Estado de justiça da Idade Média, que nos séculos XV e XVI se tornou o Estado administrativo, viu-se pouco a pouco "governamentalizado". (FOUCAULT, 2008b, p. 143-144).

Em vista dessa ideia de governamentalidade é que desconfio das narrativas que espraiam a necessidade de prevenção e uso de camisinha, bem como de tolerância em relação aos homossexuais porque, para mim - apesar de provocarem certo deslocamento - tais narrativas ainda desejam a mesmidade na medida em que tentam, a todo custo, capturar 
existências que, insubmissa e teimosamente, subvertem os esquadrinhamentos heteronormativos e biopolíticos ${ }^{5}$, bem como porque, da forma como vejo, tais narrativas não destituem o pensamento que dicotomizou nossos/nossas (sempre mutantes) corpos/práticas sexuais em um pólo considerado normal (o hétero, que se vê superior e por isso diz respeitar homossexuais) e outro pólo considerado anormal (o homo, que por se enxergar a partir da retina hétero, sente-se acolhido/hospedado por essas narrativas de tolerância e prevenção do corpo). Assim, esses apelos multiculturais soam, ao meu ver, nada naturais, pelo contrário, como criaçóes culturais que são, sustentam um jogo discursivo - agora respaldado pelos dispositivos midiáticos - que apenas rearranjam os processos biopolíticos de controle de nossos corpos e de nossas práticas sexuais/ afetivo-amorosas.

Desse modo, o que procuro focalizar nestes ditos são os atravessamentos, a memória, as contra-palavras, os efeitos de sentidos contidos em narrativas que se apresentam tâo plurais, altruístas e generosas, no sentido de verificar como esses textos que circulam em esferas pedagógicas (como o discurso midiático) - mesmo discursando em prol do respeito e da tolerância - trabalham em favor da manutenção da estabilidade (ainda que, paradoxalmente, provoquem algum descolamento) de uma identidade tida como normal (heterossexual) e de todos os eventos culturais associados a ela, bem como depreender quais os mecanismos postos em açáo para etiquetar nesses textos outra identidade tida como anormal (homossexual), portanto excêntrica, esquisita, estranha, merecedora apenas do respeito e da tolerância de alguns.

\section{A Noção Foucaultiana de Discurso}

Em primeiro lugar, é preciso dizer que, nesta análise, parto dos Estudos do Discurso para tentar compor o argumento que pretendo anunciar. Desse modo, buscar nos Estudos do Discurso calços para compor o que aqui pretendo costurar, significa puxar de tal perspectiva teórica alguns fios

5. Biopolítica, aqui, tem a ver com as estratégias de efetivação do biopoder que, segundo Foucault (2002) é aquele tipo de poder que passa a agir sobre a população. Em outros termos, podemos dizer que " $[\ldots]$ às formas teatralizadas da violência utilizadas pelo poder soberano (bio-histórico), sucede uma prática moderna caracterizada pelo reflexo do biológico na política. Os sujeitos podem passar a ser vistos como membros de uma população porque são dissecados na sua individualidade, como é o caso da sua sexualidade." (Ó, 2009, p. 110). 
conceituais que, ao serem tecidos ao olhar pós-estruturalista ${ }^{6}$, possibilitamme pensar os enunciados sobre prevenção do corpo que aparecem no discurso midiático, por exemplo, e que se configuram como mecanismos de controle do corpo e de captura de nossas práticas sexuais e afetivo-amorosas. Em vista disso, o que quero da Análise do Discurso é mais no sentido de tomá-la como perspectiva de leitura do que propriamente fazer uma transposiçẫo de seus conceitos em um objeto textual específico. Assim, a $\mathrm{AD}^{7}$ que alinhava este trabalho se assenta na compreensão foucaultiana de discurso, já que

[...] suponho que em toda sociedade toda produção do discurso é ao mesmo tempo controlada, selecionada, organizada e redistribuída por certo número de procedimentos que tem por funçáo conjurar seus poderes e perigos, dominar seu acontecimento aleatório, esquivar sua pesada e temível materialidade. (FOUCAULT, 2000, p. 9).

Por isso é que fazer $\mathrm{AD}$ não é simplesmente fazer análise de texto ou do dado empírico enunciado pelos sujeitos. É antes perceber que o

6. Conforme já disse em outro escrito, "por pós-estruturalismo estou entendendo todo um movimento de pensamento em reação à perspectiva filosófica estruturalista, através de uma teorização que passa a levar em conta, de uma maneira muito mais radical, a linguagem e os processos de significação - daí sua gestação acontecer dos insights da Linguística de Saussure, que de maneira ou outra já supunha isto - ampliando questôes chaves do estruturalismo, como a ênfase na dimensão discursiva, bem como subvertendo algumas categorias, como a ideia de fixidez semântica em troca da noção de fluidez e instabilidade do significado. De qualquer modo, o que se radicaliza na ótica pós-estruturalista é a compreensão de diferença, que passa a ser encarada não como algo que existe na relação entre um significante e um significado, mas sim como um feixe de relaçôes que diferem ininterruptamente, de modo ser impossível estancar totalmente um significado apenas num único significante, conforme as consideraçôes de Derrida, sobre a ideia de différance. Juntam-se a isso, na construçáo deste empreendimento de desestabilização promovido pelas reflexóes pós-estruturalistas, as ideias sobre redes de poder de Foucault, que desloca a assunçáo do poder como algo que se tem, fixo, bipolar em favor da ideia de poder capilar, espraiado e móvel. Assim, há todo um movimento de questionamento da noçáo de "verdade", a fim de fazer ver a tessitura histórica do que se entende como "verdadeiro", bem como mostrar como algo se torna "verdade", através de efeitos discursivos produzidos pelas relaçôes de força. Ainda é bom assinalar que o pós-estruturalismo vai por em xeque o sujeito de inspiração cartesiana, entendido pela acepçáo iluminista como o centro, soberano, racional, bem como apontar as fraturas desse sujeito, mostrando o quão descentrado ele é de si e do mundo. Para aquelas/es que querem nomes - apesar de haver certa controvérsia em relação à lista - é possível dizer, segundo Peters (2000), que se soma aos já citados Michel Foucault e Jacques Derrida, as reflexões de Gilles Deleuze e Felix Guattarri, Jean-François Lyotard, Jean Baudrillard, Julia Kristeva, dentre algumas/uns outras/os, reflexôes estas emergidas da inspiração que vêm de Nietzsche e da leitura que Heidegger fez dele." (SIERRA, 2004, p. 21).

7. AD quer dizer Análise do Discurso. 
discurso é revestido pela trama histórico-linguística que o constitui e que, portanto, é preciso desconstruir sua discursividade para enxergá-lo. Assim, a $\mathrm{AD}$ - enquanto instrumento de análise dos processos discursivos - se coloca como possibilidade de decantação do dizer, fazendo emergir, daí, as memórias, as redes e lugares discursivos que sustentam, por exemplo, os enunciados de prevenção do corpo e combate ao HIV/Aids. Por isso, não cabe à noção de discurso que quero trazer aqui nenhuma ideia universalista, causal, transcendental, pois para a $\mathrm{AD}$ que persigo não interessa nem cabe ao analista preocupaçóes com a veracidade ou falsidade de tais preposiçóes, tampouco importa tentar levantar quais as possíveis intençóes do autor, uma vez que para a noção foucaultiana de discurso é importante afastar qualquer conotaçáo de sujeito pleno de si, consciente.

Isso quer dizer que o sujeito não é a única fonte de seu dizer, mas sim de um entrecruzar de sentidos. Ao mesmo tempo em que ele pode dizer (quase) tudo, precisa se submeter a uma ordem discursiva (FOUCAULT, 2000). Como os discursos não partem de nós, ou, em outros termos, como os discursos não nos são dados anteriormente, não nascem conosco, o que fazemos é, a partir do que já foi enunciado - e esquecido ${ }^{8}$ - retomar determinadas palavras, imprimindo nelas novos/outros sentidos. Por isso que as palavras que dizemos (e isso discursivamente é difícil de delimitar), ao mesmo tempo em que são iguais, são sempre diferentes, ou seja, ao mesmo tempo em que me enxergo nas coisas que digo, enxergo um mosaico de mim naquilo que falo, como as rasuras de um texto em curso, um palimpsesto (VASCONCELOS, 2003).

Assim, interessa-me não necessariamente "quem disse o quê", mas sim, tentar escavar por que e para que determinados discursos se tornam inteligíveis e como sáo apropriados para que se possa deles dizer, em um dado tempo e lugar. Parto desta noção de discurso por entender que não há objetos que existem de maneira a priori aos saberes que os engendram e que, portanto, eles só podem existir pelo fato de surgirem de certas condiçôes discursivas (FOUCAULT, 1987). Isto é importante para evitar compreensóes que tomam os enunciados como algo que está posto anteriormente a qualquer condição, como se eles estivessem lá, em algum lugar, à espera de um olhar que os interpretasse, como se houvesse neles uma espécie de dado essencial a ser "descoberto", "revelado" ou "interpretado" pelo

8. O esquecimento no discurso é fundamental para criar a ilusão de realidade do pensamento, ou de uma relação direta entre palavra e coisa. Isso é importante, pois ao esquecer o já-dito - processo involuntário, obviamente - esse sujeito pode se ver no que diz e, assim, se constituir como tal. 
analista. Ao contrário, interessa na análise é procurar nos enunciados não dados essencialistas, mas sim tentar descrever como eles formam práticas discursivas", a partir de determinadas condições/situações. Para isso, é preciso supor não uma história, mas historicidades, todas elas descontínuas, instáveis, pluridirecionais, o que acaba implicando uma noção de história diferente daquela de sentido universal, cuja grande questão seria o estabelecimento de uma síntese apaziguadora dos movimentos contraditórios da sociedade. Quando se passa a perceber que não só as condiçôes materiais constituem a mulher e o homem, por exemplo, é possível perceber como os processos de significação, ou seja, os enunciados, as práticas discursivas, interpelam e subjetivam essas categorias.

Eis, então, a ideia de discurso que quero frisar aqui: quando falo em enunciado ou em formaçôes discursivas ${ }^{10}$, não estou tomando tais categorias só como sentenças linguísticas gramaticalizadas, uma estrutura sintático-semântica que liga significantes a significados, nem tampouco como atos de fala, em que haveria um autor responsável por aquilo que está sendo dito, como se aquilo que se está dizendo fosse, de fato, possível de ser referido a este autor como sua propriedade. O que busco aventar aqui é o discurso como algo que se enuncia para além da langue ${ }^{11}$, ou seja, para além da materialidade linguística. Dessa forma, tomo as campanhas de prevenção do corpo e combate ao HIV/AIDS que fazem parte dessa análise como enunciados que não são possíveis de serem localizados temporalmente, nem possíveis de serem atribuídos a um autor específico, já que neles ecoam flashs discursivos de outras temporalidades e espacialidades. O que importa é tentar ver como estes enunciados estáo sendo ditos agora, verificar quais outros enunciados colam-se neles para promover os

9. "Prática Discursiva" está sendo usada conforme Foucault, isto é, não portanto no sentido de uma formulação de uma ideia por um indivíduo, uma tomada racional de um sujeito falante de frases gramaticais, mas sim, como um "conjunto de regras anônimas, históricas, sempre determinadas no tempo e no espaço, que definiriam, em uma dada época e para uma determinada área social, econômica, geográfica ou linguística, as condiçóes de exercício da função enunciativa" (FOUCAULT, 1987, p. 136)

10. Para Foucault (1987), um enunciado faz parte de uma determinada formação discursiva, ou seja, a regularidade dos enunciados é definida pela formação discursiva. Desse modo, segundo ele, "a lei dos enunciados e o fato de pertencerem à formação discursiva constituem uma única e mesma coisa; o que não é paradoxal, já que a formação discursiva se caracteriza não por princípios de construção mas por uma dispersão de fato, já que ela é para os enunciados não uma condição de possibilidade, mas uma lei de coexistência, e já que os enunciados, em troca, não são elementos intercambiáveis, mas conjuntos caracterizados por sua modalidade de existência” (p. 135).

11. Langue está sendo usada, aqui, no sentido de Saussure (2002). 
sentidos que estabelecem hoje, bem como de que forma tais enunciados se convertem num projeto biopolítico (FOUCAULT, 2002, 2008a, 2008b) de controle sobre nossos corpos e práticas sexuais/afetivo-amorosas. Por isso é que não me interessa o referente em si, ou seja, minhas preocupaçóes não recaem sobre o homossexual enquanto sujeito empírico, como se fosse mesmo possível falar em termos de uma espécie de essência verdadeiramente homossexual. O que me move é a tentativa de evidenciar como os discursos sobre a homossexualidade acabam constituindo objetos (a personagem homossexual, a "bicha", o "veado", a "sapatão", por exemplo). É justamente por isso que me interessam mais as formaçóes discursivas que produzem o dado, que propriamente o dado per se.

Neste sentido, se expressôes como "gay", "homossexual", "bicha", "veado" são vistas apenas de um lugar (da norma heterossexual) é porque os sentidos que se lançam a elas são tomados como naturais - como se existisse de fato um referente empírico da homossexualidade. É preciso, pois, desnaturalizar esses sentidos, apontando seu caráter construído, destecendo as redes discursivas nas quais estão envoltos, a fim de mostrar que tais expressôes podem comportar a possibilidade de serem enxergadas de outro(s) lugare(s), portanto, podem ser vistas e encaradas a partir de outras posiçóes discursivas. A ideia de formação discursiva é pertinente, pois permite a compreensão de como acontece a produçáo de sentidos no jogo das relaçóes de poder. Não fosse apenas isso, compreender que os discursos reúnem-se nestas formaçóes é entender que, a partir de certas condiçôes discursivas (e não discursivas também) é que se define a ordem dos discursos (FOUCAULT, 2000), isto é, aquilo que pode ser dito, onde ser dito, quando ser dito, para quem ser dito.

A partir desse esquema é que se produzem imagens dos sujeitos e dos objetos do discurso, colocados no interior do processo histórico. É, portanto, um jogo imaginário que regula o dizer. Assim, temos efeitos de sentidos articulados por enunciados que representam como A e B enxergam um em relação ao outro, bem como as imagens que elaboram de seu lugar e do lugar do outro. Na campanha que recortei como corpus desta análise é possível perceber formaçōes imaginárias que designam a maneira como UM discursa o OUTRO.

Além dos jogos de imagem, tento articular o conceito de heterogeneidade constitutiva do discurso, ou seja, o envolvimento que determinado discurso estabelece com outro. Do mesmo modo, esta relação entre discursos também pode ser definida por aquilo que Authier-Revuz (1990) 
definiu como heterogeneidade mostrada, ou seja, formas linguísticas de representação de diferentes modos de negociação do sujeito falante com a heterogeneidade constitutiva do seu discurso. Quer dizer que, de maneira ou de outra, o que falamos carrega sempre (BAKHTIN, 1992, 1999) vozes de outros enunciados, isto é, o discurso é constitutivamente polifônico, o que significa que um locutor não diz o que diz pela primeira vez: todo objeto de discurso já foi antes falado, convertido, esclarecido, retextualizado. É por isso que todo discurso não pode ser tomado isoladamente das vozes outras que o constituem, pelo fato de ele relacionar-se dialogicamente com enunciados de outros interlocutores. É claro que, ao redizê-los, os enunciados se inscreverão sob novas condições (FOUCAULT, 2000), novos efeitos de sentido, o que torna estas enunciações também outras e irrepetíveis.

\section{Governamentalidade em Campanhas de Prevenção Contra HIV/ AIDS}

As campanhas atuais de prevenção do corpo continuam, para mim, ansiando a mesmidade, uma vez que vazam delas feixes discursivos que sustentam o pavor à diferença e que negam a multiplicidade sexual se ela estiver escapulindo à norma do padrão de consumo e da consciência burguesa. A normalização aparece agora, da forma como vejo, no jogo que seduz a alteridade a se expor, para que, ao saber dela, seja possível maquinar caminhos de mantê-la docilmente confortada à moral burguesa e à ordem do consumo. A normalizaçáo do presente se ajusta às reconfiguraçóes biopolíticas ${ }^{12}$ de gerenciamento da vida. Esse é o argumento que tento exemplificar, agora, a partir de alguns acontecimentos ${ }^{13}$ que fazem parte de uma campanha de prevenção contra o HIV/AIDS, promovida pelo Ministério da Saúde, em $2001^{14}$, cujo foco era os homossexuais:

12. Este termo "[...] designa a maneira pela qual o poder tende a se transformar, entre o fim do século XVII e o começo do século XIX, a fim de governar não somente os indivíduos por meio de um certo número de procedimentos disciplinares, mas o conjunto dos viventes constituídos em população: a biopolítica - por meio dos biopoderes locais - se ocupará, portanto, da gestão da saúde, da higiene, da alimentação, da sexualidade, da natalidade etc., na medida em que elas se tornaram preocupaçóes políticas." (RAVEL, 2005, p. 26)

13. A noção foucaultiana de acontecimento tem a ver com a interrogação da atualidade e com a reconstrução de uma rede de discursos, poderes, estratégias, práticas. É a análise das diferentes redes discursivas às quais um acontecimento pertence, tentando mostrar a irrupção de uma singularidade histórica que se repete na atualidade e nos atravessa ao longo do tempo.

14. É bom lembrar que outras campanhas de prevençáo contra AIDS elaboradas por ONGs e pelo governo brasileiro, surgidas após esta data, também tiveram foco nos mesmos argumentos que tento questionar aqui. Para saber mais, ver: <www.aids.gov.br/campanhas>. 


\section{Acontecimento 1:}

Propaganda veiculada na mídia impressa que trazia uma fotografia em preto e branco, de um jovem e um homem mais velho, abraçados, possivelmente representando uma relação entre pai e filho. Junto à fotografia, seguia o texto:

"Use camisinha com seu namorado. Também pode ser uma conversa de pai para filho. A orientação sexual pode variar. O respeito a ela, não. Não discrimine os homossexuais. O preconceito só atrapalha a prevenção."

\section{Acontecimento 2:}

Propaganda veiculada na mídia televisiva. Extraio, aqui, o diálogo que acompanha o desenrolar da ação:

Mãe (ao ver um rapaz se aproximando da porta) - é ele

Rapaz (depois que o pai abre a porta) - Oi, eu preciso falar...

Pai - ele não quer falar com você

Rapaz - mas, eu preciso falar com ele

Pai - não volta mais aqui não. Ele não vai falar com você

Filho (para o pai, depois que esse fecha a porta) - e aí, pai, ele já foi?

Mãe (olhando para o filho seriamente) - filho, você vai encontrar um rapaz que te mereça.

Voz em off - Usar camisinha é tão importante quanto respeitar as diferenças.

Obs.: durante a cena, há ainda a presença da irmã, que fica o tempo todo só observando a cena, sem falar nada. (Na primeira leitura, ou no início da cena, tem-se a impressão de que o rapaz que chega quer falar com a moça e não com o rapaz).

O objetivo é mostrar, entáo, a partir dos acontecimentos acima, o movimento dos processos discursivos e tentar verificar o(s) aparecimento(s) desse(s) ou daquele(s) efeito(s) de sentido, bem como, a partir disso, procurar sistematizar os percursos que os enunciados sob análise percorrem nesse sempre entrecruzar de possibilidades de construção de significados.

Desse modo, por lidarmos com um objeto (o discurso) cuja natureza é fugidia, fugaz, multifacetada e, por ser tudo isso, permitir apenas que os sentidos se estabeleçam a partir da interação dinâmica travada entre sujeitos que dizem em função de suas posições discursivas, toda análise de discurso requer que se levantem as condiçóes discursivas dos textos/objetos em questáo. 
Diante disso, esses acontecimentos apontam alguns sentidos que corroboram com a ideia de que é preciso "respeitar e tolerar as diferenças", por exemplo. Se formos começar pela estratégia utilizada, poderíamos dizer que ambas as propagandas apresentam o personagem homossexual náo como ele costumeiramente aparece nos meios midiáticos, ou seja, estereotipado, com trejeitos femininos, que acabaram por construir um gênero quase próprio: o do homossexual bicha-louca, de salto alto, maquiagem na cara, voz estridente e gestos exagerados.

Pelo contrário, a imagem que as propagandas tentam passar é a de um gay supostamente fora desse estereótipo, portanto, desatrelado da invenção caricata que o discurso midiático cria em torno da homossexualidade masculina, por exemplo. Temos, assim, no acontecimento veiculado na mídia impressa, a figura (em preto-e-branco) de um jovem, mais ou menos 20 anos, bonito e saudável - em relação ao padrão que se estabeleceu para tais adjetivos, claro - exalando "masculinidade" e "felicidade", dado o sorriso aberto com que se deixa flagrar. Como se náo bastasse isso, temos ainda outra figura, a do pai do jovem, com um meio-sorriso estampado no rosto, o que dá a impressão de satisfação em relação ao filho, portanto de família feliz e centrada.

Como qualquer discurso sempre evoca outras vozes em sua constituição, há neste anúncio a presença do discurso patriarcal, conservador, numa tentativa de articulação e proximidade entre o universo gay e a ideia de uma sociedade heterocentrada na figura do pai de família.

Estas imagens provocam a sensação de que é necessário valorizar a homossexualidade, não porque se entende que a diferença situa-se na dobra, fora do centro, mas sim porque é importante respeitá-la, pois, desse modo, a homossexualidade poderá ser puxada ao centro hegemônico para, a partir desta racionalidade, normalizar-se na prática do sexo seguro. Quer dizer que o discurso de prevenção do corpo se apoia na ideia de respeito aos homossexuais, na tentativa de criar a ilusão de que os homossexuais só ganharáo o direito de estar no centro considerado normal se mantiverem comportamentos sexuais e cuidados com o corpo de acordo com o que estabelecem as biopolíticas (FOUCAULT, 2008a, 2008b) que gerenciam nossa vida. O biopoder, de que nos fala Foucault (2002), coloca-se como uma espécie de controle sobre o problema que é a população, um problema ao mesmo tempo econômico, político, científico e biológico, que precisa ser controlado - estimulando a vida ou ignorando a morte - para que, 
estrategicamente, se regulamentem e normatizem, de modo especial, as sexualidades, já que o que está em jogo é o controle da natalidade, das formas de procriação, das doenças, da vida saudável:

Eu creio que, se a sexualidade foi importante, [no século XIX] foi por uma porção de razóes, mas em especial houve duas: de um lado, a sexualidade, enquanto comportamento exatamente corporal, depende de um controle disciplinar, individualizante, em forma de vigilância permanente (...) e, depois, por outro lado, a sexualidade se insere e adquire efeito, por seus efeitos procriadores, em processos biológicos amplos que concernem não mais ao corpo do indivíduo mas a esse elemento, a essa unidade múltipla constituída pela população. (FOUCAULT, 2002, p. 300).

Além disso, há ainda, neste caso, uma espécie de enredamento discursivo que, apesar de se dizer tolerante, engendra a soberania daquele que tolera (heterossexual), em relação à subordinação do corpo daquele que é tolerado (homossexual). Como, ao longo de tempos, discursou-se que o normal é estar no centro, que o padrão saudável são os comportamentos sexuais burgueses, a sensação que se tem é a de que as práticas sexuais desviantes do modelo heteronormativo precisam se aproximar o mais perto possível das práticas tidas como corretas e saudáveis. Para o projeto biopolítico isso é extremamente interessante, pois, via essa lógica, constrói-se a ideia da importância da prevenção do corpo, o que diminuiria possíveis gastos com tratamentos de doenças, bem como possibilitaria a construção de corpos viáveis, sempre prontos ao trabalho e ao consumo.

Este acontecimento parece, ainda, conclamar os pais para essa missão, já que enuncia, em letras grandes, que "essa também pode ser uma conversa de pai para filho", mais uma vez emergindo, nestes enunciados, a memória discursiva de outros, como o de ditos populares, por exemplo, que forçam a ideia de que a "educação começa em casa", só para citar um caso. Isto é, se pode ser uma conversa entre pai e filho significa que a valorização das diferenças sexuais precisa começar em casa, numa referência ao discurso de que se "cada um fizer a sua parte, começando em casa, as coisas mudam".

O que interessa aqui é o entrecruzamento desses outros discursos que, ao serem retomados e ressignificados, passam agora a compor um 
outro discurso. Assim, é importante assinalar aqui a relação que todo discurso mantém com o discurso-outro, o que define a noção de heterogeneidade constitutiva do discurso. Assim, as formaçóes discursivas não são blocos homogêneos, elas incorporam elementos pré-construídos, que podem ser redefinidos, incorporados, redimensionados, retextualizados, apagados. Todo discurso nasce, portanto, do trabalho com outros discursos. Por isso, uma formação discursiva articula outras, pois "toda unidade de sentido, qualquer que seja seu tipo, pode estar inscrita em uma relação essencial com outra, aquela dos discursos em relaçáo aos quais o discurso de que lhe deriva define sua identidade." (MAINGUENEAU, 1989, p. 120). Trata-se, assim, de marcar que o objeto do analista do discurso não é uma formação discursiva única, exclusiva, mas sim, o interdiscurso, ou seja, a interação dialógica entre formaçôes discursivas.

Outra leitura possível refere-se ao fato de que, logo abaixo do enunciado principal, há vários outros ("A orientação sexual pode variar"; "O respeito a ela, não."; "Não discrimine os homossexuais."; "O preconceito só atrapalha a prevençáo.”), conclamando o leitor a essa ideia de respeito/ tolerância com o diferente, cada qual com uma cor (amarelo, azul, violeta), cromotografia esta que nos faz acionar um dos mais conhecidos símbolos do movimento LGBT ${ }^{15}$ : o arco-íris. As cores estabelecem com a fotografia do pai e filho em preto-e-branco uma relação que, antes de ser antagônica, constrói uma espécie de diálogo, possível de se travar, entre o dito impactante e provocativo universo LGBT e o construído/discursivisado austero e conciliador mundo familiar.

O segundo acontecimento foi veiculado na mídia televisiva e, a partir dele, é possível ler/ver a configuração de uma família tipicamente burguesa: pai, mãe, filho (primogênito) e filha (caçula). Essa organização familiar deixa vazar a tentativa de construção de uma narrativa cujos personagens componham o mais próximo possível uma família heterocentrada. Ora, o efeito que a propaganda articula é o de que é preciso deixar claro, para todos, que não é porque há no contexto familiar um membro que seja diferente, um membro que escapuliu à ordem imposta pelo pensamento heteronormativo, que essa família vai deixar de reproduzir a mesma lógica de tantas outras famílias comuns por aí.

15. LGBT é a sigla usada pelo movimento homossexual brasileiro que, a partir da consolidação das políticas identitárias nos anos 90, resolve adotar esta denominação que quer dizer lésbicas, gays, bissexuais, travestis e transexuais. 
Além disso, outro fator que merece ser avaliado diz respeito à maneira como é apresentada a relação mãe-filho/pai-filho. Há toda uma preocupação em tentar convencer o leitor de que a homossexualidade está sendo encarada da maneira mais natural e complacente possível, como se, ao falarem, os personagens reproduzissem o posicionamento do governo em relação ao tema. Em miúdos: quando a mãe diz, por exemplo, "filho, você vai encontrar um rapaz que te mereça", o efeito que se institui é o de que na voz da mãe está presente o discurso governamental sobre a relação homem X homem, até porque há, pressupostamente nesta fala, a necessidade de cuidados neste tipo de relação, ou seja, o filho até poderá encontrar um rapaz que o mereça, desde que o outro concorde em usar camisinha, que consinta em prevenir o corpo contra eventuais doenças. Essa ideia fica ainda mais reforçada quando, ao final do texto, surge aquela voz em off, sentenciadora, disciplinarizante, inculcadora, dizendo que "usar camisinha é tão importante quanto respeitar as diferenças".

Enfim, esses exemplos fazem pensar que, talvez, a celebração do diferente não está na ordem do dia porque as pessoas de fato estejam menos homofóbicas ou mais tolerantes, por exemplo. Ao contrário, talvez essa celebração envolva muito mais um jogo de captura e controle, em que o outro é celebrado como forma de ajustá-lo ao projeto contemporâneo de governamentalidade dos corpos e práticas sexuais/afetivo-amorosas.

Não quis com essas leituras que ora apresento dizer que o uso da camisinha não seja importante, tampouco quis dizer que não temos que nos prevenir contra doenças como a AIDS ou, ainda, que campanhas publicitárias como estas não surtam (mesmo que colocadas na dimensão do controle do corpo e do sexo) efeitos no combate a uma doença que, entendo, precisa, certamente, ser evitada. Quis tão somente problematizar esses enunciados, tão em voga, sobre a prevenção do corpo, tentando apontar nuances, implícitos, contra-discursos em um discurso que se pretende táo altruísta, renovador e imparcial, bem como mostrar, com a ajuda, especialmente de Foucault, a genealogia dessas retóricas que se estandardizam hoje, mas que trazem consigo os respingos de um projeto que se iniciou com a Pastoral da Carne e a confissão, passou pelo dispositivo da sexualidade e seus saberes médico-psiquiátricos, desembocou na psicanálise e seus métodos de saber do outro e se radicaliza, agora, com o discurso midiático agindo como instância promotora das estratégias de governamentalidade de nossos corpos e nossas praticas sexuais/afetivo-amorosas. 


\section{REFERÊNCIAS}

AUTHIER-REVUZ, Jacqueline. Heterogeneidade(s) enunciativa(s). Cadernos de Estudos Linguísticos, Campinas, v. 19, p. 25-42, jul./dez.1990.

BAKHTIN, Mikhail. Estética da criaçáo verbal. São Paulo: Martins Fontes, 1992.

Marxismo e filosofia da linguagem. 9. ed. Trad. de Michel Lahud e Yara Frateschi Vieira. São Paulo: Ucitec, 1999.

FISCHER, Rosa Maria Bueno. O estatuto pedagógico da mídia: questôes de análise. Educaçáo e Realidade, Porto alegre, v.22, n.2, p.59-79, jul/dez. 1997.

FOUCAULT, Michel. A arqueologia do saber. 3. ed. Rio de Janeiro: Forense-Universitária, 1987.

A ordem do discurso. 6. ed. São Paulo: Edições Loyola, 2000.

. Em defesa da sociedade. São Paulo: Martins Fontes, 2002.

Nascimento da Biopolítica. São Paulo: Martins Fontes, 2008a.

Segurança, território, populaçáo. São Paulo: Martins Fontes, 2008b.

HALL, Stuart. A identidade Cultural na pós-modernidade. 5. ed. Trad. de Tomaz Tadeu da Silva e Guacira Lopes Louro. Rio de Janeiro: DP\&A, 2001.

MAINGUENEAU, Dominique. Novas tendências em análise do discurso. Trad. de Freda Indursky. Campinas: Pontes, 1989.

Ó, Jorge Ramos do. A governamentalidade e a história da escola moderna: outras conexões investigativas. Educaçáo \& Realidade, Porto Alegre, v. 34, n. 2, p. 117-97, maio/ago. 2009.

REVEL, Judith. Foucault. Conceitos essenciais. Trad. de Maria do Rosário Gregolin et. al. São Carlos: Claraluz, 2005.

SAUSSURE, Ferdinand de. Curso de linguística geral. 24. ed. Trad. de Antônio Chelini, José Paulo Paes e Izidoro Bliksdein. São Paulo: Cultrix, 2002.

SIERRA, Jamil Cabral. Homossexuais, insubmissos e alteridade em transe: representaçóes da homocultura na mídia e a diferença no jogo dos dispositivos contemporâneos de normalização. 2004. 131 f. Dissertação (Mestrado em Letras) Universidade Estadual de Maringá, Maringá, 2004.

VASCONCELOS, Silvia Inês C. C. de. O début, o inaugural no discurso do professor de português como língua estrangeira sobre sua formação profissional. In: CORACINI, Maria José (Org.). Identidade e discurso. Chapecó: Argos/Campinas: Editora da Unicamp, 2003. p. 161-185. 


\title{
A PRESENÇA DA DIVERSIDADE CULTURAL NAS PESQUISAS SOBRE FORMAÇÃO DOCENTE
}

\author{
André Luiz Sena Mariano \\ Universidade Federal de Alfenas
}

O multiculturalismo tem sido apontado pela literatura como um desafio inescapável do mundo atual. Autores como Kincheloe (1997), por exemplo, afirmam que o multiculturalismo náo se trata de algo com o qual se concorde ou acredite, ele é uma condição da qual não se pode esquivar. Além disso, Imbernón (2004) considera que o enfrentamento das problemáticas referentes à desigualdade social e econômica e à diversidade cultural são aspectos que a formação docente, neste século, não poderá mais ignorar.

É a partir desse cenário que este trabalho, parte de uma pesquisa mais ampla, se debruça sobre a temática da formação docente na perspectiva multicultural, propondo compreender quais tendências podem ser encontradas (por exemplo, instituiçóes de origem, categorias multiculturais pesquisadas, tipos de estudo, tendências teóricas, entre outros) e quais as concepçóes de multiculturalismo podem ser encontradas nos resultados dos trabalhos selecionados.

Para que isso seja possível, este texto se estrutura em quatro seçóes: na primeira, é apresentada a base teórica a partir da qual o multiculturalismo é assumido por este estudo; na segunda, é explicitado o caminho metodológico percorrido para a coleta de dados; na terceira, são identificadas as principais características dos estudos selecionados; na quarta e última, 
o texto discute as concepçóes de multiculturalismo que foram encontradas nos textos que compuseram o corpus de análise.

\section{Pelas sendas da teorização}

Abordar a temática multicultural coloca como imperativa a definição da acepção a partir da qual os dados são analisados. Isso porque o termo multiculturalismo, como é bem sabido, é polissêmico e abriga, amiúde, interpretaçôes antagônicas. Neste sentido, uma possível definição das diferentes acepçóes pode ser encontrada em McLaren (2000). Para o autor, haveria ao menos quatro formas de interpretar o multiculturalismo, a saber: o multiculturalismo conservador, o liberal de esquerda, o humanista liberal e o crítico. Em vez de explicitar as definiçóes de cada uma dessas tendências, aqui será apresentada, sumariamente, a abordagem crítica que é a assumida por este estudo.

De acordo com McLaren (2000), a perspectiva crítica assume que as representaçóes relativas à raça, classe social e gênero fazem parte de lutas sociais mais amplas sobre os signos e as significaçóes. Essa perspectiva assume que o discurso está inerentemente relacionado a formas de reprodução e resistência. $\mathrm{O}$ autor advoga que a tarefa central da perspectiva multicultural crítica seria a transformação das relaçôes sociais, culturais e institucionais a partir das quais os signos e os significados são gerados. Sendo assim, ganham destaque três conceitos que estariam no cerne da preocupação multicultural: a diferença, a identidade e a relação entre maioria e minoria.

Na perspectiva crítica, a escola precisa ser considerada como envolta nas relaçôes de conflitos, poder e interesses, pois é ela a responsável pelo processo de transmissão cultural. Além disso, valemos-nos dos argumentos de Pérez Gómez (1995) ao considerar a escola como um espaço de encruzilhada de culturas.

\section{Caminho metodológico}

Tendo em vista a questáo central que acompanhou este estudo - o que revelam os estudos produzidos e publicados no Brasil, quando abordam a inserção do multiculturalismo na formação docente? Foi necessário obedecer a alguns critérios e percorrer algumas etapas para a seleção dos estudos que se enquadravam na temática em foco. 
No que tange a isso, foi estabelecido como corpus de investigação os trabalhos apresentados nas reunióes anuais da ANPEd ${ }^{1}$, nos eventos do ENDIPE $^{2}$ e os artigos publicados em periódicos qualificados entre os anos de 2000 e 2006. Dentre os textos apresentados e publicados nas três fontes, foram privilegiados aqueles que focalizavam a formação docente e suas interfaces com as questôes multiculturais. Tal interface poderia se dar de maneira explícita, com a utilização de referenciais e categorias estreitamente vinculados ao multiculturalismo, ou potencial. Para a categoria potencial, foi utilizado o trabalho de Canen, Arbache e Franco (2001), que define o trabalho com potencial multicultural como aquele que, a partir da análise de categorias como raça, classe social e gênero, por exemplo, "manda recados" para o campo do multiculturalismo.

Com base nessas duas categorias, os textos foram selecionados a partir da leitura dos títulos, dos resumos e dos textos integrais. A partir desses procedimentos, foram considerados foco desta pesquisa 13 artigos publicados em periódicos qualificados (sendo $11 \mathrm{com}$ potencial multicultural), 17 trabalhos apresentados nas reunióes anuais da ANPEd (sendo 8 com potencial multicultural) e 27 trabalhos apresentados nos eventos do ENDIPE (sendo 11 com potencial multicultural). Tal situação já revela a incipiente presença explícita do multiculturalismo dentre os estudos selecionados.

Além disso, fez-se mister identificar nos textos selecionados dados como ano de publicação e/ou apresentação, instituição, categoria multicultural focalizada, âmbito da formação docente focalizado, componente curricular, vínculo multicultural, tipo de estudo e autores mais utilizados.

Para elaborar os quadros que ora se apresentam, serviram como referência os trabalhos de André (2000) e Brzezinski e Garrido (2006). Destes, foram emprestadas as conceituações referentes à formação de professores, bem como bases para a compreensão dos tipos de estudo realizados.

Os trabalhos de Canen, Arbache e Franco (2000) e Moreira (2001) também nos serviram como fundamento para a construção dos quadros. Do primeiro, foram tomados os conceitos de trabalhos com vinculação explícita ou potencial ao multiculturalismo. Do segundo, as categorias de preocupação de análise da teoria multicultural, tais como raça/etnia, classe social, gênero, sexualidade, idade e diversidade cultural, entre

1. Associação Nacional de Pós-Graduação e Pesquisa em Educação.

2. Encontro Nacional de Didática e Prática de Ensino. 
outras, funcionaram como fundamentação para a categorização dos dados encontrados.

Ciente de que toda categorizaçáo é precária, este trabalho de organização dos dados em quadros tem mais uma função heurística que a de uma fronteira rígida de enquadramento dos trabalhos. Os dados que se seguem são frutos da leitura do autor, sendo possíveis outras leituras dos mesmos dados.

\section{Revelando os dados iniciais}

Entre os anos de 2000 e 2006, foi encontrado um número ainda pequeno de trabalhos que focalizaram, conjuntamente, as discussões sobre multiculturalismo e formação de professores. Foram considerados como pertencentes ao foco deste estudo: 13 artigos publicados nos periódicos avaliados como Internacional e Nacional A, 17 trabalhos apresentados na ANPEd e 27 trabalhos apresentados no ENDIPE.

Se for levada em conta a categoria criada por Canen, Arbache e Franco - trabalhos com potencial multicultural - os números diferem nas três fontes. Para os artigos publicados em periódicos, 11 dos 13 selecionados foram considerados com vínculo explícito ao multiculturalismo. Já para os trabalhos apresentados na ANPEd, 8 dos 17 foram classificados como explicitamente multiculturais. Por fim, no ENDIPE, 11 dos 27 foram considerados com tal característica, situação que pode ser vislumbrada no quadro a seguir.

Quadro 1: Organização dos trabalhos quanto ao vínculo com a temática multicultural

\begin{tabular}{|c|c|c|c|}
\multicolumn{5}{|c}{} & $\begin{array}{c}\text { TOTAL DE } \\
\text { TEXTOS }\end{array}$ & $\begin{array}{c}\text { FOCO MULTICULTURAL } \\
\text { EXPLÍCITO }\end{array}$ & $\%$ \\
\hline Artigos & 13 & 11 & 84,6 \\
\hline $\begin{array}{c}\text { Trabalhos } \\
\text { ANPEd }\end{array}$ & 17 & 8 & 47 \\
\hline $\begin{array}{c}\text { Trabalhos } \\
\text { ENDIPE }\end{array}$ & 27 & 11 & 40,7 \\
\hline TOTAL & 57 & 30 & 52,6 \\
\hline
\end{tabular}

Como pode ser verificado no quadro, os trabalhos com vínculo explícito ao referencial do multiculturalismo compóem pouco mais da metade do total selecionado. Se as análises fossem restritas aos trabalhos ancorados explicitamente no multiculturalismo, o quadro seria bastante reduzido de 
estudos. Contudo, a categoria criada por Canen, Arbache e Franco (2000) "trabalhos com potencial multicultural" contribui para, além de ampliar o número de estudos que seria selecionado inicialmente, compreender que pesquisas sobre gênero, raça, classe social ou necessidades especiais, por exemplo, ainda que náo sejam ancoradas no referencial multicultural, mas tomadas a partir da perspectiva das relaçóes entre escola e cultura, poderiam auxiliar na compreensão de outras facetas de tratamento das questóes culturais no âmbito educacional.

Sendo assim, os dados permitem inferir que a formação de professores analisada a partir da perspectiva multicultural explícita ainda é um tema pouco explorado. Assim, corrobora-se a afirmaçáo de Candau (2001), quando discorre sobre as propostas relativas à formação de professores. Embora suas argumentaçóes fossem referentes à década de 1990, em que ela julgava haver pouco avanço na formaçáo de professores, menos pela existência de um aprofundamento teórico e de propostas concretas e mais por uma falta de vontade política, tais palavras se mostram atuais e pertinentes. De acordo com ela, "[...] as questóes culturais e seu impacto sobre a escolarização não têm sido incluídas de forma explícita e sistemática nos processos de formação docente" (CANDAU, 2001, p. 238).

A esta discussão, é importante acrescentar as ponderaçóes de Canen (2001), para quem a morosidade e resistência para a inserção das questôes culturais na formação de professores pode ser corolário do lento processo de reconhecimento do Brasil como um país multicultural. Isso porque predominou, e ainda paira no ideário da sociedade, o mito da democracia racial. Ademais, cabe ressaltar que tal situação ainda pode ser explicada pelos efeitos às avessas que podem ocorrer em função de uma apropriaçáo banalizada do multiculturalismo. Em outras palavras, como corolário de uma leitura e apropriação frágeis, superficiais e banalizadas da teoria multicultural, alguns setores da sociedade advogam que é uma forma de se interpretar o processo educativo por meio da exclusão das pessoas brancas, ricas, cristâs, heterossexuais, jovens, bonitas, em perfeitas condições físicas, do sexo masculino, etc. Assiste-se a uma construção de ferrenhas críticas à teoria que vem questionar a manutenção do status quo da sociedade. Nesse sentido, Semprini (1999) afirma que o multiculturalismo tem sido visto como uma ameaça à sociedade branca, no caso, a dos Estados Unidos da América. Essa leitura equivocada do multiculturalismo faz supor que, no tocante à formação de professores, os currículos devam privilegiar 
somente as experiências das mulheres, dos negros, dos pobres, dos índios, dos homossexuais e dos portadores de necessidades especiais, desprezando as formas convencionais de construção do conhecimento.

Outro dado encontrado nos estudos é referente ao ano de publicação dos artigos ou de apresentação dos trabalhos nos eventos.

Quadro 2: Organização dos trabalhos quanto ao ano de apresentação e publicação

\begin{tabular}{|c|c|c|c|c|c|}
\multicolumn{2}{|c}{ ARTIGOS } & $\begin{array}{c}\text { Trabalhos } \\
\text { ANPEd }\end{array}$ & $\begin{array}{c}\text { Trabalhos } \\
\text { ENDIPE }\end{array}$ & TOTAL & $\%$ \\
\hline 2000 & 0 & 1 & 2 & 3 & 5,3 \\
\hline 2001 & 4 & 1 & Não há evento & 5 & 8,8 \\
\hline 2002 & 1 & 3 & 6 & 10 & 17,5 \\
\hline 2003 & 2 & 2 & Não há evento & 4 & 7,0 \\
\hline 2004 & 2 & 2 & 8 & 12 & 21,1 \\
\hline 2005 & 3 & 5 & Não há evento & 8 & 14,0 \\
\hline 2006 & 1 & 3 & 11 & 15 & 26,3 \\
\hline TOTAL & 13 & 17 & 27 & 57 & 100 \\
\hline
\end{tabular}

Está óbvio que o maior número de trabalhos apresentados nos anos de 2002, 2004 e 2006 se deve à ocorrência do ENDIPE. Contudo, o que chama a atençáo são os dados da ANPEd. Parece ter havido um aumento no interesse pela temática no ano de 2005. Contudo, o que se verifica é o que o GT Formaçáo de Professores não teve trabalhos selecionados, explícita ou potencialmente multiculturais, nos anos de 2000, 2001 e 2006.

A produção da ANPEd esteve dispersa em cinco GTs.

Quadro 3: Organização dos trabalhos quanto ao GT em que foram apresentados nas Reuniōes Anuais da ANPEd

\begin{tabular}{|c|c|c|}
\hline GT - GRUPO DE TRABALHO & No de trabalhos & $\begin{array}{c}\text { \% referente à } \\
\text { produçáo da ANPEd }\end{array}$ \\
\hline GT 6 - Educação Popular & 2 & 11,8 \\
\hline GT 8 - Formação de Professores & 7 & 41,2 \\
\hline GT 12 - Currículo & 4 & 23,5 \\
\hline GT 15 - Educação Especial & 1 & 5,9 \\
\hline GT 21 - Afro-Brasileiros e Educação & 3 & 17,6 \\
\hline TOTAL & 17 & 100 \\
\hline
\end{tabular}


Os dados encontrados no quadro 3 , concernentes à dispersão da teoria multicultural entre os GTs, podem ser explicados pela própria constituição do multiculturalismo: uma teoria híbrida e que busca respaldo em diferentes áreas do conhecimento (Antropologia, Sociologia, Economia e Linguística, por exemplo). Em contrapartida, a própria constituição da Associação por GTs acaba dando uma suposta ideia de dispersão temática dos trabalhos, mesmo encontrando vários GTs que se propóem a discutir trabalhos que focalizem problemáticas afins. Destarte, também chama a atenção o fato de que alguns GTs que poderiam ser considerados como diretamente envolvidos com preocupaçóes multiculturais não tenham apresentado produçôes sobre o tema, como, por exemplo, os GTs de Movimentos Sociais e Educação e Gênero, Sexualidade e Educação.

Para os artigos em periódicos, foi encontrado, exceto no ano de 2000, um número pequeno de trabalhos que articulam o multiculturalismo e a formação docente. No ENDIPE, pode-se inferir que trabalhos relacionando a formaçáo de professores ao multiculturalismo têm sido apresentados e mostram algum crescimento, ainda que tímido.

As instituições de origem dos trabalhos também se mostraram um dado revelador. Para este item, surpreende a forte presença das universidades do estado do Rio de Janeiro.

Quadro 4: Organização dos trabalhos quanto às instituições de origem

(continua)

\begin{tabular}{|c|c|c|c|c|}
\hline $\begin{array}{c}\text { NOME DA INSTITUIÇÃO } \\
\text { Centro Universitário do Planalto de Araxá } \\
\text { (UNIARAXÁ) }\end{array}$ & 0 & 1 & 0 & 1,7 \\
\hline $\begin{array}{c}\text { ONG - Novamérica } \\
\text { ONPEd }\end{array}$ & 0 & 0 & 1 & 1,7 \\
\hline $\begin{array}{c}\text { Pontifícia Universidade Católica do Rio de } \\
\text { Janeiro (PUC-Rio) }\end{array}$ & 1 & 0 & 0 & 1,7 \\
\hline Universidade Católica de Petrópolis (UCP) & 0 & 0 & 1 & 1,7 \\
\hline Universidade Católica Dom Bosco (UCDB) & 0 & 1 & 0 & 1,7 \\
\hline Universidade de Aveiro (Portugal) & 0 & 0 & 1 & 1,7 \\
\hline Universidade de Brasília (UnB) & 0 & 1 & 0 & 1,7 \\
\hline Universidade de Sáo Paulo (USP) & 1 & 0 & 0 & 1,7 \\
\hline Universidade de Uberaba (UNIUBE) & 0 & 1 & 0 & 1,7 \\
\hline Universidade do Estado de Santa Catarina & 0 & 0 & 1 & 1,7 \\
\hline
\end{tabular}


(conclusão)

\begin{tabular}{|c|c|c|c|c|}
\hline NOME DA INSTITUIÇÃO & Artigos & ANPEd & ENDIPE & $\%$ \\
\hline Universidade do Estado do Ceará (UECE) & 0 & 0 & 1 & 1,7 \\
\hline Universidade do Vale do Itajaí (UNIVALI) & 0 & 1 & 0 & 1,7 \\
\hline $\begin{array}{c}\text { Universidade Estadual de Campinas } \\
\text { (UNICAMP) }\end{array}$ & 1 & 0 & 0 & 1,7 \\
\hline $\begin{array}{c}\text { Universidade Estadual do Rio Grande do } \\
\text { Norte (UERN) }\end{array}$ & 0 & 0 & 1 & 1,7 \\
\hline $\begin{array}{l}\text { Universidade Estadual Paulista (UNESP/ } \\
\text { Bauru) }\end{array}$ & 0 & 0 & 1 & 1,7 \\
\hline Universidade Federal da Paraíba (UFPB) & 0 & 1 & 0 & 1,7 \\
\hline $\begin{array}{l}\text { Universidade Federal de Minas Gerais } \\
\text { (UFMG) }\end{array}$ & 1 & 0 & 0 & 1,7 \\
\hline $\begin{array}{l}\text { Universidade Federal de Santa Catarina } \\
\text { (UFSC) }\end{array}$ & 1 & 0 & 0 & 1,7 \\
\hline Universidade Federal de Santa Maria (UFSM) & 0 & 0 & 1 & 1,7 \\
\hline Universidade Federal do Espírito Santo (UFES) & 0 & 1 & 0 & 1,7 \\
\hline Universidade Federal do Pará (UFPA) & 0 & 0 & 1 & 1,7 \\
\hline Universidade Federal do Pernambuco (UFPE) & 0 & 0 & 1 & 1,7 \\
\hline Universidade Federal Fluminense (UFF) & 0 & 1 & 0 & 1,7 \\
\hline $\begin{array}{l}\text { Universidade Metodista de Piracicaba } \\
\text { (UNIMEP) }\end{array}$ & 0 & 1 & 0 & 1,7 \\
\hline $\begin{array}{l}\text { Universidade do Vale do Rio dos Sinos } \\
\text { (UNISINOS) }\end{array}$ & 0 & 0 & 2 & 3,6 \\
\hline $\begin{array}{l}\text { Universidade Estadual Paulista (UNESP/ } \\
\text { Presidente Prudente) }\end{array}$ & 0 & 0 & 2 & 3,6 \\
\hline Universidade Federal de Uberlândia (UFU) & 0 & 1 & 1 & 3,6 \\
\hline $\begin{array}{l}\text { Universidade Federal do Rio Grande do Sul } \\
\text { (UFRGS) }\end{array}$ & 0 & 0 & 2 & 3,6 \\
\hline Universidade Federal do Amazonas (UFAM) & 1 & 1 & 1 & 5,6 \\
\hline Universidade Federal de Juiz de Fora (UFJF) & 0 & 2 & 2 & 7,4 \\
\hline $\begin{array}{c}\text { Universidade do Estado do Rio de Janeiro } \\
\text { (UERJ) }\end{array}$ & 0 & 1 & 5 & 10,6 \\
\hline Universidade Federal do Rio de Janeiro (UFRJ) & 7 & 3 & 2 & 21,2 \\
\hline TOTAL & 13 & 17 & 27 & 100 \\
\hline
\end{tabular}

Se os dados forem organizados por estado, a centralidade do Rio de Janeiro na temática de multiculturalismo e formaçáo de professores é evidente. 
Dos 57 trabalhos, 22 foram produzidos por universidades fluminenses (quase $40 \%$ da produção). O segundo estado é o de Minas Gerais, que responde pela autoria de 9 trabalhos, enquanto 6 estudos são oriundos de São Paulo e 5 do Rio Grande do Sul. Em seguida, Amazonas e Santa Catarina aparecem com 3 trabalhos; Ceará, Distrito Federal, Espírito Santo, Mato Grosso do Sul, Pará, Paraíba, Pernambuco e Rio Grande do Norte têm 1 trabalho cada. Ainda é possível identificar um trabalho proveniente de Portugal.

Legitimando dados de pesquisas de levantamentos anteriores, a Região Sudeste é o principal núcleo de produção dos trabalhos sobre a temática da formação de professores na perspectiva multicultural, fato este explicado pelo alto número de programas de pós-graduação existentes na regiáo. Todavia, a diferença para os estudos anteriores é que para a temática em pauta, a centralidade não está no estado de Sáo Paulo, que responde por cerca de $10 \%$ da produçáo, a despeito de ser aquele que possui o maior número de programas de pós-graduação. A partir dessas constatações, pode-se inferir que o celeiro das preocupaçóes multiculturais é o estado do Rio de Janeiro, responsável por quase $40 \%$ da produção sobre a temática.

As pesquisas de estado da arte realizadas por André (2000) e por Brzezinski e Garrido (2006) auxiliaram na verificaçáo das categorias que foram privilegiadas nas pesquisas sobre formação de professores. Dessa forma, foram categorizados os estudos a partir dos âmbitos analisados, a saber: formação inicial, formação continuada, identidade e profissionalização docente, prática pedagógica e políticas de formação, entre outros.

Quadro 5: Organização dos trabalhos quanto ao âmbito da formação pesquisado

\begin{tabular}{|c|c|c|c|c|c|}
\hline $\begin{array}{c}\text { TEMAS DA } \\
\text { FORMAÇÃO }\end{array}$ & 1 & 1 & 0 & 2 & 3,5 \\
\hline $\begin{array}{c}\text { Concepçóes sobre docência e } \\
\text { formação de professores }\end{array}$ & 0 & 0 & 1 & 1 & 1,7 \\
\hline $\begin{array}{c}\text { Identidade e } \\
\text { profissionalizaçáo docente }\end{array}$ & 2 & 1 & 1 & 4 & 7,1 \\
\hline Revisão de literatura & 1 & 5 & 1 & 7 & 12,3 \\
\hline Formação continuada & 0 & 2 & 4 & 6 & 10,5 \\
\hline Trabalho docente & 2 & 4 & 10 & 16 & 28,1 \\
\hline Formação inicial & 7 & 4 & 10 & 21 & 36,8 \\
\hline Propostas e políticas de formação & 13 & 17 & 27 & 57 & 100 \\
\hline TOTAL & & & & & \\
\hline
\end{tabular}


De acordo com o exposto no quadro 5, pode-se verificar que os temas da formação inicial e das propostas e políticas de formação são aqueles que mais têm sido estudados no que se refere ao referencial do multiculturalismo.

Para o tema "concepções sobre docência e formação inicial de professores", os subtemas privilegiados foram: a discussão sobre fundamentos epistemológicos da formação de professores e as concepçóes de professores formadores sobre pesquisa em educação. No tema "identidade e profissionalização docente", o foco esteve na discussão sobre a autonomia e suas interfaces com a construção da identidade profissional. Ademais, há quatro estudos sobre revisão de literatura: três (um artigo, um trabalho na ANPEd e um no ENDIPE) focalizam a temática do multiculturalismo nas dissertaçôes e teses; o outro (um artigo) analisa a temática da formação de educadores para a atuação na educação sexual.

$\mathrm{Na}$ categoria "formação continuada", os sete estudos focalizaram o subtema projetos e programas de formação promovidos por secretaria, órgãos de financiamento, universidades e/ou $\mathrm{ONGs}^{3}$.

Para o tema "trabalho docente", das duas pesquisas apresentadas na ANPEd, uma focaliza o ensino fundamental e outra o estudo da prática docente também no ensino fundamental. Do total de trabalhos apresentados no ENDIPE, dois são sobre saberes docentes em diferentes níveis de ensino (fundamental e superior) e com diferentes componentes curriculares (História e Música) e os outros dois focalizam estudos da prática docente, também em diferentes níveis de ensino (fundamental e superior).

Com relação à "formação inicial", a situação é a seguinte: dois estudos focalizam a formação em nível Médio, na modalidade magistério (um artigo e um trabalho no ENDIPE); um (na ANPEd) focaliza o curso Normal Superior; 8 focalizam o curso de Pedagogia (dois trabalhos na ANPEd e 6 no ENDIPE); um (na ANPEd) o curso de Pedagogia da Terra; um (no ENDIPE) focaliza Licenciatura em Física; um (artigo) integra análises nos cursos de Pedagogia e História; um focaliza formação de professores em Pedagogia e Psicologia; e outro realiza um estudo histórico sobre a formação inicial de professores homens.

Destes estudos, alguns ainda centram a atenção no trabalho com componentes curriculares específicos. No que se refere a isso, dos dois

3. Organizações Não-Governamentais. 
estudos sobre a formação de professores em nível Médio, um único artigo centra a atenção na disciplina Filosofia da Educação. Para os 7 trabalhos sobre o curso de Pedagogia, 4 centram sua atenção em componentes curriculares específicos, a saber: dois sobre a disciplina Prática de Ensino (ambos do ENDIPE), um a disciplina Educação Especial (na ANPEd) e um trabalho apresentado na ANPEd focaliza uma disciplina denominada Tópicos Especiais em Multiculturalismo e Educação.

Por fim, a maior parte dos estudos se encontra na categoria "políticas e propostas de formação de professores". Os 7 artigos selecionados e que foram considerados como referentes ao tema tratam das seguintes subcategorias: dois sobre propostas de formação para a diversidade cultural, dois sobre políticas de currículo e de formação e três abordam os novos espaços (loci) para a formação de professores, como, por exemplo, o Conselho dos Professores Indígenas da Amazônia, os salóes étnicos e o Movimento Sem Terra.

Os três trabalhos apresentados na ANPEd revelam os seguintes subtemas: um sobre políticas de formação, um sobre a formação de professores para a diversidade cultural e um sobre os novos espaços para a formação (o Conselho dos Professores Indígenas da Amazônia). Dos 10 trabalhos apresentados no ENDIPE, o subtema "políticas de formação" foi abordado por um trabalho; "os novos espaços de formação" também foi tema abordado por um trabalho; enquanto a formação de professores para a diversidade cultural e para a educação inclusiva foi uma subcategoria focalizada por 9 trabalhos.

Após essa apresentação alusiva ao âmbito da formação de professores focalizado pelos estudos, é possível apresentar algumas tendências:

a) A grande quantidade de estudos que refletem sobre e apresentam propostas de formaçáo, tanto inicial quanto continuada, para a atuaçáo dos professores visando ao trabalho com a diversidade cultural;

b) a tendência dos estudos à centralização das análises a partir do curso de Pedagogia;

c) um número considerável de trabalhos sobre formação continuada, especialmente tomando como ponto de análise os novos espaços formativos. Talvez, pelo fato de o multiculturalismo ter nascido no seio dos movimentos sociais, essa busca pela formaçáo docente em espaços não escolares seja um sinalizador do reconhecimento de outras instâncias 
também formadoras de professores, e esses novos loci formativos são focalizados nas pesquisas sobre os movimentos sociais e sobre a etnia indígena.

Assim, sinaliza-se que a formação de professores, em seus vários âmbitos, e especialmente no da continuada, conforme apontam os estudos, não pode mais centralizar sua atenção exclusivamente na educação escolar. Quem sabe essa possa ser uma perspectiva promissora para a busca do diálogo entre o conhecimento produzido no estado de estudante e no estado de esquina de rua (MCLAREN, 1992).

Porém, é possível depreender, também, que os dados mais interessantes seguem na contramáo do que foi constatado nos estudos de André (2000) e Brezinski e Garrido (2006). Neles, as autoras sinalizaram que os estudos concernentes à identidade e profissionalização docente se construíram tomando as relaçóes de gênero como perspectiva de análise. Neste estudo, foi constatado que, primeiro, a categoria gênero é quase silenciada no que se refere à formação de professores na perspectiva multicultural; segundo, que o único estudo que abordou identidade e profissionalização docente, sequer mencionou as relaçóes de gênero; e terceiro, que os estudos sobre gênero sequer mencionaram a temática da identidade. Deste modo, as palavras de Paraíso (2002), ao advogar que o gênero é um campo de silêncio nos currículos da formação de professores, parecem ainda fazer sentido. Embora náo possa mais ser considerado um campo de silêncio, é possível afirmar que sua presença ainda é incipiente.

Outro dado pertinente ao foco deste texto é identificar, nos textos selecionados, quais foram as categorias multiculturais privilegiadas. Para tanto, foi assumido como referência o trabalho de Moreira (2001). Os estudos selecionados apresentam seus respectivos focos nas seguintes categorias:

Quadro 6: Organização dos estudos quanto à categoria multicultural abordada

\begin{tabular}{|c|c|c|c|c|c|}
\hline \multicolumn{1}{|c|}{ CATEGORIAS } & ARTIGOS & \multicolumn{1}{c}{ ANPEd } & ENDIPE & TOTAL & $\%$ \\
\hline Diversidade Cultural & 8 & 6 & 17 & 31 & 54,3 \\
\hline Etnia / raça & 2 & 5 & 2 & 9 & 15,8 \\
\hline Necessidades especiais & 1 & 2 & 3 & 6 & 10,5 \\
\hline Classe social & 1 & 2 & 2 & 5 & 8,8 \\
\hline Gênero e sexualidade & 1 & 1 & 1 & 3 & 5,3 \\
\hline Geração (Jovens e Adultos) & 0 & 1 & 2 & 3 & 5,3 \\
\hline TOTAL & 13 & 17 & 27 & 57 & 100 \\
\hline
\end{tabular}


É possível pensar na localização geográfica das categorias. Se o estado do Rio de Janeiro foi apontado no quarto quadro como o celeiro dos estudos multiculturais, o mesmo não se pode afirmar quando são analisados os dados das categorias de maneira mais específica. No que concerne a isso, é possível apontar a existência de uma dispersão temática. Por exemplo, na categoria formaçáo de professores e classe social, os cinco trabalhos foram produzidos, cada um deles em lugares distintos (Espírito Santo, Minas Gerais, Pará, Rio Grande do Norte e Santa Catarina). Para os trabalhos da categoria "formação de professores e etnia/raça", os quatro que focalizaram a temática da raça negra tiveram Minas Gerais com dois trabalhos e Rio de Janeiro e Santa Catarina com um trabalho cada. Já dos quatro sobre a questão indígena, dois são do estado do Amazonas, um do Mato Grosso do Sul e um de Santa Catarina. Dos seis trabalhos sobre formação de professores e necessidades especiais, quatro foram produzidos em universidades do estado de Minas Gerais, ao passo que dos 31 textos sobre formação de professores e diversidade cultural, 18 são do Rio de Janeiro.

Quatro aspectos chamam a atenção nesse panorama traçado:

a) A alta concentraçáo de estudos sobre diversidade cultural no Rio de Janeiro (quase 60\% do total sobre o tema);

b) A presença firme de Minas Gerais nos estudos sobre formação de professores e necessidades especiais (do total de 6 trabalhos, 4 foram produzidos nesse estado - $66,7 \%$ do total);

c) A presença do estado de São Paulo na categoria formação de professores e gênero e sexualidade (dos 3 estudos sobre a temática, 2 foram produzidos nesse estado);

d) A presença do Amazonas na temática formação de professores e a questão indígena (dos 4, 2 foram produzidos no estado).

Identificar o tipo de estudo realizado mostrou-se como outro dado relevante nos trabalhos selecionados. Para que isso fosse possível, a base referencial foi composta pelos trabalhos de André (2000), Moreira (2001) e Brzezinski e Garrido (2006). A organização deste quadro tomou como principal pressuposto a classificação oferecida pelos próprios autores dos trabalhos. 
Quadro 7: Organização dos trabalhos quanto ao tipo de estudo realizado

\begin{tabular}{|c|c|c|c|c|}
\hline TIPO DE ESTUDO & \multicolumn{1}{c}{ ARTIGOS } & ANPEd & ENDIPE & $\%$ \\
\hline Revisão de literatura & 2 & 1 & 1 & 7,0 \\
\hline Reflexão conceitual & 2 & 2 & 3 & 12,3 \\
\hline Etnografia & 3 & 1 & 2 & 10,5 \\
\hline Análise documental & 2 & 4 & 2 & 14,0 \\
\hline Análise do discurso & 1 & 1 & 1 & 5,4 \\
\hline Estudo de caso & 0 & 0 & 3 & 5,4 \\
\hline Pesquisa-açáo & 1 & 1 & 2 & 7,0 \\
\hline Análise de conteúdo & 0 & 0 & 2 & 3,5 \\
\hline Pesquisa participante & 0 & 1 & 0 & 1,7 \\
\hline Estudo histórico & 0 & 0 & 1 & 1,7 \\
\hline Análise microgenética & 0 & 1 & 0 & 1,7 \\
\hline Relato de experiência & 0 & 1 & 1 & 3,5 \\
\hline Não menciona & 2 & 4 & 9 & 26,3 \\
\hline TOTAL & 13 & 17 & 27 & 100 \\
\hline
\end{tabular}

O que chama a atenção é o alto índice de trabalhos que não mencionam o tipo de estudo realizado. Muitos sequer explicitam os procedimentos utilizados para a coleta de dados.

É possível afirmar que, a partir dos textos selecionados, aqueles que afirmam construir estudos de inspiração etnográfica combinam três procedimentos básicos de coleta dos dados: a entrevista, a observação - nem sempre participante - e a análise documental. Dessa forma, fomos levados a concluir que a confusão entre metodologia e procedimento, para esse tipo de estudo, não acontece com a mesma frequência que em outros.

Aqueles que advogam a construção de estudos do tipo etnográfico, o fazem baseados em André (2001). De acordo com essa autora, tais estudos teriam algumas características, tais como:

a) A associação de técnicas tradicionalmente afeitas à etnografia: a observação participante, a entrevista intensiva e a análise de documentos;

b) A ênfase no processo, naquilo que ocorre quando da coleta dos dados, e não somente no produto final;

c) A preocupação com o significado, com a maneira própria com que as pessoas veem a si mesmas, às suas experiências e ao mundo que as cerca;

d) O trabalho de campo, entre outros. 
Os trabalhos que afirmam terem feito "pesquisa-ação" constroem a fundamentação metodológica a partir de dois autores: Thiollent (2008), para quem

[...] a pesquisa-ação é um tipo de pesquisa social com base empírica que é concebida e realizada em estreita associação com uma ação ou com a resoluçáo de um problema coletivo e no qual os pesquisadores e os participantes representativos da situação ou do problema estão envolvidos de modo cooperativo ou participativo. (THIOLLENT, 2008, p. 16).

Já para Barbier, tal modalidade de pesquisa tem 5 características básicas: a rejeição aos conceitos do positivismo (objetividade, racionalidade, etc.), o emprego de categorias interpretativas dos participantes do processo, o questionamento crítico sobre ideias e interpretaçóes, o empenho em verificar o que funciona como impeditivo a uma mudança racional e a premissa de que se trata de um conhecimento prático.

A análise microgenética é outra forma de pesquisa que aparece nos estudos. Aqueles que a fazem afirmam ser uma forma de construção dos dados que requer detalhes e o recorte de episódios interativos. O exame de tais situaçôes é orientado para o funcionamento dos chamados sujeitos focais, para as relaçôes intersubjetivas e para as condiçóes de atuação. Estes aspectos resultam num relato minucioso dos acontecimentos em análise.

As pesquisas que justificam a opção metodológica pela análise do discurso se fundamentam, sobretudo, no conceito de discurso e mudança social de Fairclough. Para este autor, e de acordo com os estudos selecionados, tem havido uma mudança no funcionamento e nas práticas sociais de linguagem, que a colocam em posição estratégica nas transformaçóes sociais. $\mathrm{O}$ discurso passa a ter uma função importante na constituição das identidades, sobretudo no posicionamento dos sujeitos em contextos específicos.

A análise de conteúdo é uma técnica de pesquisa privilegiada pelos estudos selecionados e que contou com a sustentação teórico-metodológica. Bardin é quem serve como fundamentação para esse tipo de estudo. Essa técnica metodológica envolve as etapas de explicitação, sistematização e expressão do conteúdo das mensagens, exigindo que sejam levados em conta a análise do emissor e o contexto no qual as mensagens foram geradas. 
As demais opçóes metodológicas encontradas no universo selecionado não apresentam fundamentação teórica para suas escolhas. Tal fato pode ser decorrente da confusão ainda persistente entre metodologia e procedimentos metodológicos e, também, do limite imperioso dos trabalhos, uma vez que, amiúde, tais textos representam recortes de trabalhos mais extensos, como dissertaçóes de mestrado e teses de doutorado.

Se forem elencados os dados referentes aos procedimentos utilizados para a coleta de dados, uma característica chama atenção: a grande maioria dos trabalhos conjuga mais de um procedimento para a análise dos dados. A entrevista continua sendo o mais utilizado, aparecendo em quase $80 \%$ dos estudos. Em contrapartida, foram poucos - para ser mais preciso, dois trabalhos - que a utilizaram como procedimento único na coleta de dados. Frequentemente, ela vem acompanhada de questionários, observações - participantes ou não - e análises documentais. Os trabalhos que afirmam terem feito análise documental, geralmente agregam a entrevista como uma técnica mais elucidativa para o esclarecimento e a construção dos dados encontrados.

O que se pode notar é que, nos estudos aqui selecionados, só há menção às técnicas expostas acima: entrevista, questionário, observaçáo e análise documental. Não foi verificada a existência de outras técnicas para a coleta de dados no universo selecionado.

Compreender quais autores foram mais utilizados pelos estudos selecionados também se mostrou uma tarefa importante. Isso porque tal aspecto dá o tom das tendências teóricas das pesquisas sobre multiculturalismo e formação de professores, ou seja, auxilia na compreensão dos lugares teóricos a partir dos quais as questóes têm sido trabalhadas e compreendidas. Neste sentido, constata-se a seguinte situação:

Quadro 8: Organização dos autores mais citados nos trabalhos

(continua)

\begin{tabular}{|c|c|c|c|c|}
\hline \multicolumn{1}{|c}{ AUTORES } & ARTIGOS & \multicolumn{1}{c}{ ANPEd } & \multicolumn{1}{c|}{ ENDIPE } & TOTAL \\
\hline Antonio Flavio B Moreira & 10 & 4 & 7 & 21 \\
\hline Ana Canen & 9 & 3 & 5 & 17 \\
\hline Peter McLaren & 3 & 4 & 7 & 14 \\
\hline Vera Maria Candau & 5 & 6 & 3 & 14 \\
\hline Tomaz Tadeu da Silva & 4 & 6 & 3 & 13 \\
\hline Marli André & 5 & 3 & 4 & 12 \\
\hline Stuart Hall & 1 & 3 & 7 & 11 \\
\hline
\end{tabular}


(conclusäo)

\begin{tabular}{|c|c|c|c|c|}
\hline \multicolumn{1}{|c|}{ AUTORES } & ARTIGOS & \multicolumn{1}{c|}{ ANPEd } & \multicolumn{1}{c|}{ ENDIPE } & TOTAL \\
\hline Paulo Freire & 0 & 3 & 7 & 10 \\
\hline António Nóvoa & 3 & 3 & 7 & 10 \\
\hline José Gimeno Sacristán & 3 & 2 & 4 & 9 \\
\hline Henry Giroux & 3 & 1 & 4 & 8 \\
\hline
\end{tabular}

A forma utilizada foi a contagem direta das referências contidas ao final dos trabalhos. Em outras palavras, foram acessadas as referências e listados todos os autores mencionados, independentemente do número de obras utilizadas ou citações feitas no corpo do texto. Em muitos casos, há autores que possuem mais de uma obra num mesmo estudo ou são citados várias vezes. Mostrou-se importante compreender mais a influência dos autores para os estudos que o número de obras e citaçóes feitas nos estudos selecionados.

A partir deste quadro, é possível identificar uma tendência crítica na compreensão do multiculturalismo. Nos estudos que versam sobre a formação de professores, identifica-se a influência dos autores ancorados na perspectiva multicultural crítica.

Contudo, os resultados dos estudos selecionados revelam que o termo multiculturalismo, conforme fora discutido por Gonçalves e Silva (2004), por exemplo, é carregado de polissemia e acepções por vezes divergentes. Dessa forma, embora o quadro anterior revele uma ligeira predominância da perspectiva crítica, as múltiplas formas de interpretação de fenômeno se mostraram como uma grande marca da pesquisa sobre formação de professores e multiculturalismo. Esta discussão será aprofundada na próxima seção deste texto.

O que os resultados dos estudos revelam sobre as acepções de multiculturalismo?

Ao cotejar estes dados com a literatura que serve de referência, sobretudo McLaren (2000), encontra-se, minimamente, a presença de cinco acepçôes de multiculturalismo. As duas primeiras são aquelas que foram encontradas pelos estudos, na análise de seus dados, quais sejam: a perspectiva conservadora e a liberal de esquerda. As outras três se referem às que estão localizadas no plano da teoria - assumida pelos textos - ou para confrontar a realidade ou como utopia, como devir. Neste sentido, encontram-se a perspectiva crítica, a pós-colonial e a intercultural. 
Ao analisar os resultados que os 57 estudos selecionados encontraram, chama atenção a forte presença das perspectivas conservadoras e liberal de esquerda. De acordo com McLaren (2000), na perspectiva conservadora, predomina uma visáo folclórica dos diferentes, que assume uma certa concepção evolucionista da humanidade, uma vez que a supremacia branca acaba por "biologizar" os negros como criaturas. Aqueles que diferem do padrão estabelecido - os negros, as mulheres, os não cristãos, os homossexuais e os pobres, entre outros - são as criaturas inferiores.

O multiculturalismo conservador apresenta cinco características nefastas para a compreensão das relações humanas. A primeira delas é a recusa em tratar a "branquidade" como uma forma de etnia. As categorias dominantes - cristão, rico, homem, heterossexual e europeu, entre outras - não são assumidas como categorias a partir das quais as diferenças e identidades podem ser construídas e, sobretudo, são submetidas ao jugo das relaçóes de poder e da ideologia.

Uma segunda característica é a utilização do termo diversidade como forma de camuflar a ideologia que sustenta as posiçôes defendidas. Essa característica implica, de acordo com McLaren (2000), em uma postura onde os inferiores precisam se camuflar, se despir de suas identidades e de sua história cultural para se juntarem à turma. É o que o autor denomina por 'tornar-se um sujeito sem propriedades', solicita-se do indivíduo seu desnudamento, sua "desracialização" e um despir-se de sua história para ser considerado alguém com direito de se unir à turma.

A terceira característica é o estabelecimento de um mundo monoidiomático, com a prevalência do inglês. Novamente, requer-se que o indivíduo se torne um sujeito sem propriedade.

$\mathrm{Na}$ quarta característica, definem-se padrôes de desempenho que são válidos para todos os indivíduos e, por fim, a quinta característica se refere ao conhecimento considerado pertencente à elite. Náo há um questionamento acerca das relaçóes de poder que cerceiam as oportunidades escolares daqueles que destoam do padrão estabelecido.

Além do multiculturalismo conservador, constata-se a existência da acepção liberal de esquerda. De acordo com McLaren:

Aqueles e aquelas que trabalham dentro desta perspectiva têm uma tendência a essencializar as diferenças culturais e, portanto, ignorar a 
situacionalidade histórica e cultural da diferença, a qual é compreendida como uma forma de significação retirada de suas restriçôes históricas e sociais. (MCLAREN, 2000, p. 120).

Essa perspectiva, encontrada nos resultados dos estudos selecionados, assume a diferença como um dado que essencializa as relaçóes sociais e que existe independente das relaçóes de poder, da história e da cultura. Os dados dos trabalhos sinalizam um conceito de diferença como harmônico, consensual, descontextualizado e anistórico. A dimensão política da prática pedagógica, da identidade e da diferença é ignorada. A relação entre o professor, o conhecimento e seus alunos é marcada pela verticalidade e pelo autoritarismo. O conhecimento é produzido, geralmente, no âmbito das universidades e, aos professores, cabe o papel de mero reprodutor, sem questionamentos. Esta mesma postura passiva e conformista, que é impingida aos professores, acaba por ser transmitida aos alunos. Sobre isso, Kincheloe afirma:

A rede ideológica formada por este autoritarismo produz um currículo que ensina os professores e alunos a como pensar e agir no mundo. Ambos, professores e estudantes, são educados para o conformismo, para ajustarem suas diferenças e seus lugares na escala social e para submeterem-se à autoridade. Professores e estudantes são induzidos a desenvolver uma dependência da autoridade, uma visão de cidadania que é passiva, uma visão de aprendizagem que significa escutar. (KINCHELOE, 1997, p. 223).

Embora a perspectiva tecnocrática, de cunho positivista, apregoe a neutralidade da prática educativa, a partir do excerto acima fica evidente que o caráter político é inerente a ela: a política da passividade, do conformismo e da manutenção do status quo. Seria como mostramos na seção anterior: a formação e atuação de intelectuais adaptados (GIROUX, 1987) que não se comprometem e que engendram discursos e práticas que visam à manutenção dos interesses da classe dominante.

Essas duas vertentes de multiculturalismo - a conservadora e a liberal de esquerda - parecem revelar que, a julgar pelos resultados encontrados nos textos selecionados, a formação de professores em nosso país acaba por transformar a diferença em desigualdade, a identidade em padronização 
e a cultura em uma quintessência que existe para além do poder de ação dos indivíduos. Ao sujeito cabe, nessa forma de lidar com a realidade, o papel de um ser que se adapta a um mundo preestabelecido.

Os resultados sinalizam, ainda, para a contramáo do que afirma Paulo Freire (2005) sobre a capacidade de o indivíduo intervir na história, de fazer-se sujeito de seu ser, estar e mover-se no mundo. Isso porque, ao assumir uma acepçáo conservadora, a formação docente acaba ensejando a preparaçáo de profissionais que somente de adaptam ao mundo e que se veem como determinados pelo contexto histórico e pelas raízes culturais das quais se nutrem. O ser humano acaba por ser determinado pela sua história de vida e não pode fazer diferente.

Apesar de terem sido encontradas essas duas acepçóes nos resultados dos textos, a literatura adotada por eles para análise dos dados assume outras perspectivas teóricas. Neste sentido, encontram-se três formas pelas quais o multiculturalismo pode ser visto, com destaque para a perspectiva do multiculturalismo crítico e de resistência de Peter McLaren (2000).

Se os dados dos estudos mostram que a diferença e a identidade são tratadas como etéreas, na perspectiva crítica esses são conceitos fortemente ligados às relaçóes de poder. A diferença é sempre relacional, sendo um produto da história, da cultura, das relaçôes de poder e da ideologia. Ademais, a cultura não pode ser vista como algo consensual, mas necessariamente conflitivo, marcado pelo dissenso e pelas relaçóes de poder. De acordo com McLaren:

Diferenças dentro da cultura devem ser definidas como diferenças políticas e não apenas como diferenças textuais, linguísticas, formais. As relações de poder estruturais e globais não devem ser ignoradas. [...] Diferenças são sempre diferenças em relação, elas nunca são simplesmente flutuações livres. Diferenças não são vistas como absolutas, irredutíveis ou intratáveis, mas, em vez disso, como polivocais e relacionais, social e culturalmente. (MCLAREN, 2000, p. 133).

A diferença apresentada nos resultados encontrados pelos trabalhos acaba não sendo um aspecto cultural, tampouco polivocal. Há uma única forma de lidar com ela: essencializada, homogeneizante, desviante e fruto de aspectos biológicos e psicológicos. Em resumo, ao invés de ser tratada como um dado enriquecedor da realidade, a diferença torna-se 
desigualdade, pois inferioriza os desviantes, estigmatiza a "outridade" em detrimento da "mesmidade".

Uma segunda acepção encontrada nos trabalhos selecionados é a denominada de "interculturalismo". Alguns estudos sinalizam o avanço de tal postura em relação ao multiculturalismo por acreditarem na existência de trocas e de relaçóes estabelecidas entre as culturas. No que se refere a isso, Candau (2005) afirma:

A interculturalidade orienta processos que têm por base o reconhecimento do direito à diferença e a luta contra todas as formas de discriminação e desigualdade social. Tenta promover relaçôes dialógicas e igualitárias entre pessoas e grupos que pertencem a universos culturais diferentes, trabalhando os conflitos inerentes a essa realidade. Não ignora as relaçóes de poder presentes nas relaçôes sociais e interpessoais. Reconhece e assume os conflitos, procurando as estratégias mais adequadas para enfrentá-los. (CANDAU, 2005, p. 32).

A acepçáo multicultural parece não trazer embutida no nome uma perspectiva de diálogo e troca como o faz a perspectiva intercultural. Multicultural seria somente uma característica da sociedade, pois o mundo é inescapavelmente multicultural. Porém, o termo intercultural, pelo que os estudos que o defendem revelam, traz em si a perspectiva de interpenetração das culturas. Vale retomar aqui o conceito de hibridismo (HALL, 2005), a partir do qual as culturas entram em processos de interação, sem que isso implique, necessariamente, na imposição da cultura supostamente hegemônica sobre a outra.

Uma terceira acepção, que confronta a teoria apresentada nos resultados, é o multiculturalismo pós-colonial. Tal perspectiva é definida por Canen, Arbache e Franco (2001) como uma

[...] visão intercultural crítica, especialmente enriquecida e tensionada por sensibilidades pós-coloniais que têm trazido, para o centro das reflexóes, questôes referentes à construção das identidades plurais e híbridas, entendidas como centrais para a concretização do multiculturalismo crítico. De fato, dentro dessa perspectiva teórica, a compreensão das identidades como constituídas em espaços e discursos plurais, incluindo os educacionais, leva 
à rejeição de posturas que naturalizam e essencializam essas mesmas identidades. (CANEN; ARBACHE; FRANCO, 2001, p. 3).

Acredita-se que a diferença entre a perspectiva pós-colonial e a crítica é a forma de se conceber a identidade. $\mathrm{O}$ multiculturalismo crítico supostamente lida com as identidades de maneira polarizada e binária (homem em oposição à mulher), enquanto a perspectiva pós-colonial lida com as possibilidades de fronteiras híbridas entre as escolhas identitárias. Seria uma forma de lidar com o conceito de identidade e de cultura de maneira semelhante à sugerida por Hall (2005), quando o autor define a identidade do sujeito pós-moderno.

Autores como McLaren (2005) definem a pedagogia ou multiculturalismo pós-colonial como um movimento que busca, nesta era de globalização, a problematização dos discursos pedagógicos com vistas ao final dos imperialismos baseada no conceito de "estado-nação". McLaren defende que essa perspectiva não se reduz ao anti-imperialismo, pois é uma pedagogia voltada também para o anti-racismo, a anti-homofobia e outras reivindicaçóes de grupos social, cultural, histórica e politicamente desfavorecidos. Porém, o avanço estaria no desafio das características e das condiçôes a partir das quais a história dos grupos colonizados foi escrita. Ou seja, é uma reconstrução da diferença, de modo que ela desafie o capitalismo global desvelando seu caráter excludente e romântico em relação a como o outro - que neste caso não é o euroamericano - é construído.

Além de compreender as diferentes acepções de multiculturalismo, analisar a forma pela qual os principais conceitos - diferença, identidade e relação entre maioria e minoria - apareceram nos estudos, mostrou-se outro dado importante na compreensão do tratamento das questóes multiculturais na formação docente.

Para o tratamento dispensado ao conceito de identidade, verifica-se que na maioria dos estudos selecionados há uma maneira fixa de tratar a identidade, tanto por meio dos resultados encontrados quanto por meio do referencial teórico adotado. Não obstante os imperativos postos pelas características e extensóes dos textos selecionados, há estudos que tratam as categorias multiculturais isoladamente, sem uma conexão ou uma compreensão mais híbrida. Os estudos que focalizam a temática racial, 
por exemplo, centram as análises somente nessa categoria, não havendo análises que a relacionem com a classe social ou com o gênero. Além disso, não há estudos que apontam para a multiplicidade de posições dos sujeitos ou para uma forma híbrida de compreensáo das identidades, o que acaba denotando uma concepção essencializada do conceito de identidade.

A maneira pela qual os estudos tratam as categorias multiculturais revela uma concepção binária da identidade: a identidade do gênero feminino sempre em oposiçáo a do gênero masculino e a identidade negra em oposição à identidade branca. Não se fala, nos estudos selecionados, na identidade como processo. Ademais, verifica-se, com apenas uma exceção, que a identidade e a diferença não foram abordados conjuntamente ou mutuamente interdependentes. Os estudos que analisam a diferença se preocupam somente com ela, valendo a mesma constatação para a identidade. Em suma, a identidade também tem sido tratada de maneira essencializante. Além disso, os estudos lidam com as categorias de maneira isolada, sem tratar dos atravessamentos e do hibridismo das categorias entre si. A identidade é compreendida de maneira polarizada e acaba por marcar posiçôes fixas para os indivíduos.

O conceito de diferença, por exemplo, reiterando o que já fora mencionado anteriormente, é assumido como derivado de fatores biológicos ou psicológicos. Assim, acaba por assumir um caráter essencializante, homogeneizante e que enseja a desqualificação e desigualdade entre os indivíduos. A diferença, da maneira como vem sendo tratada na formação docente, acaba por ser aquela que inferioriza. No plano teórico dos estudos, todos assumem uma acepção de crítica e de superação das limitaçóes, propondo a assunção da diferença como um dado cultural, histórico e social.

Para as discussóes referentes às relaçóes entre maioria e minoria, não foram encontradas mençóes explícitas. As poucas discussóes referentes à temática, quando o fazem, acabam por assumir uma perspectiva bipolar, como "oprimido versus opressor", por exemplo. Os grupos minoritários acabam sendo tratados de maneira homogênea, esquecendo-se, por exemplo, de levar em consideração o fato de que, mesmo em seu interior, não há uníssono nas reivindicações e nas maneiras de viver e construir social e culturalmente as identidades, como defende Hall (2005). 
Finalizando, mas não concluindo...

Toda essa denúncia a respeito do tratamento do multiculturalismo na formação de professores encontrada nos estudos selecionados decorre das discrepâncias entre as diferentes acepções de multiculturalismo. Os resultados dos textos selecionados revelam práticas de formação ainda ancoradas nas perspectivas conservadora e liberal de esquerda, enquanto a base teórica dos textos assume acepçóes mais críticas para a análise dos dados.

Com isso, vê-se legitimada a discussão acerca da polissemia implicada no termo multiculturalismo, sobretudo, a existência das acepçóes propostas por McLaren (2000). Isso porque, de um lado, encontram-se, a julgar pelos resultados dos 57 textos selecionados, práticas que reforçam o tratamento do multiculturalismo como uma mera questáo de tolerância e de adaptação à sociedade capitalista, de outro, ressalta-se a existência de uma perspectiva de trabalho com o multiculturalismo, assumida como base teórica dos estudos, que não se coadune ao que a maioria detectou nos dados e que busca a construção de uma educação emancipatória e democrática como sugerida pelo multiculturalismo crítico.

Não obstante sua importância para a definição de formas de se lidar com as questóes e temáticas referentes à diversidade cultural, essa "disputa" que se coloca no plano teórico - multiculturalismo crítico, pós-colonial e interculturalismo - não pode ser mais importante que a compreensão da maneira pela qual a formação, em seus vários âmbitos, tem assumido o tratamento das questóes referentes à diversidade cultural.

No que toca a isso, é pertinente apresentar os questionamentos de Moreira (2001) quando realizou uma pesquisa de estado da arte sobre a produção científica acerca do multiculturalismo no campo do currículo. Para o autor:

Não será a concepção de inter/multiculturalismo que adotarmos mais importante que o prefixo a ser empregado? Não será, na verdade, a concepção de cultura que escolhermos que irá conferir ao processo ou um caráter estático ou um caráter dinâmico, produtivo? Não estamos acentuando interaçôes e trocas, tanto no interior das culturas como entre elas, ao concebermos cultura como um conjunto de práticas de significação, que se desenrolam em meio a relaçóes de poder, a conflitos, e que contribuem para formar identidades sociais? Não será a clara expressão de um compromisso 
político contra toda e qualquer coerção - que nos encaminhe a desafiar, no currículo, os preconceitos, os estereótipos e os processos que nos têm categorizado e oprimido - mais importante que a preocupação com o prefixo usado? (MOREIRA, 2001, p. 74).

É importante reiterar que não se trata de negar a importância das diferentes acepçôes de multiculturalismo para o avanço do conhecimento e da compreensão da maneira pela qual a escola e, consequentemente, a formação de professores, incorpora e lida com as suas problemáticas centrais - a diferença, a identidade e a relação entre maioria e minoria. Em contrapartida, é importante advogar, primeiramente, que é preciso fazer com que a abordagem multicultural crítica adentre o campo da formação de professores, a julgar pelos resultados que foram encontrados pelos textos selecionados. É preciso fazer com que ela tenha ecos para além da teoria, chegando às múltiplas dimensóes curriculares da formação docente. É necessário fazer com que o compromisso político que desafia o currículo e a construção de estereótipos, sugerido por Moreira (2001), a luta de Freire (2005) pelos menos favorecidos e a necessidade de alinhamento aos fracos, falando a verdade ao poder, como sugere Said (2005), cheguem à formação de nossos professores, tanto em sua dimensão inicial quanto continuada.

\section{REFERÊNCIAS}

ANDRÉ, M. (Org.). Formaçáo de professores (1990-1998). Brasília: MEC/INEP/ COMPED, 2000.

. Etnografia da prática escolar. 6.ed. Campinas - SP: Papirus, 2001.

BRZEZINSKI, I.; GARRIDO, E. Formaçáo de profissionais da educaçáo (1997-2002). Brasília: MEC/INEP/COMPED, 2006.

CANDAU, V. Pluralismo cultural, cotidiano escolar e formação de professores. In: (Org.). Magistério: construçáo cotidiana. 4. ed. Petrópolis - RJ: Vozes, p. 237-250, 2001. CANEN, A.; ARBACHE, A. P.; FRANCO, M. Pesquisando multiculturalismo e educação: o que dizem as dissertaçóes e teses. Educaçáo e Realidade, v. 26, n. 1, Porto Alegre - RS, p. 161-181, 2001.

CANEN, A. Formação de professores e diversidade cultural. In: CANDAU, V. M. (Org.). Magistério: construçáo cotidiana. 4.ed. Petrópolis - RJ: Vozes, 2001, p. 205-236.

FREIRE, P. Pedagogia da autonomia: saberes necessários à prática educativa. 31. ed. São Paulo: Paz e Terra, 2005. 
GIROUX, H. Escola crítica e política cultural. São Paulo: Autores Associados, 1987.

GONÇALVES, L. A. O.; SILVA, P. B. G. O jogo das diferenças: o multiculturalismo e seus contextos. Belo Horizonte - MG: Autêntica, 2004.

HALL, S. A identidade cultural na pós-modernidade. 10. ed. Rio de Janeiro: DP\&A, 2005.

IMBERNÓN, F. Formaçáo docente e profissional: formar-se para a mudança e a incerteza. 4.ed. São Paulo: Cortez, 2004.

KINCHELOE, J. A formaçáo do professor como compromisso político: mapeando o pósmoderno. Porto Alegre - RS: ArtMed, 1997.

MCLAREN, P. Rituais na escola: em direçáo a uma economia política de símbolos e gestos na educaçáo. Petrópolis - RJ: Vozes, 1992.

Multiculturalismo crítico. 3.ed. São Paulo: Cortez, 2000.

. Multiculturalismo revolucionário: pedagogia do dissenso para o novo milênio. Porto Alegre - RS: ArtMed, 2005.

MOREIRA, A. F. B. A recente produção científica sobre currículo e multiculturalismo no Brasil (1995-2000): avanços, tensóes e desafios. Revista Brasileira de Educaçáo. Número 18, p. 81-65, set./out./nov./dez. 2001.

PARAÍSO, M. A. Gênero na formaçáo do/a professor/a: campo de silêncio no currículo? Texto apresentado na 18 ${ }^{\mathrm{a}}$ Reunião Anual da ANPEd, Caxambu - MG: 1995.

PÉREZ GÓMEZ, A. La escuela, encrucijada de culturas. Investigación en la escuela - Las escuelas en la escuela y la cultura de la escuela, n. 26, p. 7-23, 1995.

SAID, E. Representaçóes do intelectual: as conferências Reith de 1993. São Paulo: Companhia das Letras, 2005.

SEMPRINI, A. Multiculturalismo. Bauru - SP: EDUSC, 1999.

THIOLLENT, M. Metodologia da pesquisa-açáo. 16.ed. São Paulo: Cortez, 2008. 


\section{AUTORAS E AUTORES}

Alexandre Sebastiáo Ferrari Soares possui graduação em Letras pela Universidade Federal do Rio de Janeiro (1989), mestrado em Letras pela Universidade Federal do Paraná (1999) e doutorado em Letras pela Universidade Federal Fluminense (2006). Atualmente é professor adjunto da Universidade Estadual do Oeste, atuando no Programa de PósGraduação em Letras. Tem experiência na área de Linguística, com ênfase em Análise do Discurso, atuando principalmente nos seguintes temas: discurso jornalístico, sexualidade e homossexualidade e resistência.

André Luiz Sena Mariano é graduado em Pedagogia pela Universidade Estadual Paulista (UNESP/Campus de Araraquara) e possui mestrado e doutorado em Educação (Área de Concentração em Metodologia de Ensino), ambos pela Universidade Federal de Sáo Carlos. Atualmente, é professor adjunto do Instituto de Ciências Humanas e Letras (ICHL) da Universidade Federal de Alfenas (UNIFAL/MG), concursado na área de Fundamentos da Educação. É pesquisador cadastrado junto à Rede Latinoamericana de Estudos sobre o Trabalho Docente (RED ESTRADO). Tem experiência na área de Educação, atuando principalmente nos seguintes temas: relaçóes de gênero e sexualidade, formação de professores, trabalho docente, currículo e estudos culturais.

Anete Abramowicz possui graduação em Ciências Sociais pela Universidade de São Paulo (1979), mestrado em Educação: História, Política e Sociedade pela Pontifícia Universidade Católica de São Paulo (1992) e doutorado em Educação pela Universidade Estadual de Campinas (1998). Atualmente é professora associada nível 3 da Universidade Federal de São Carlos. Em 2010 concluiu um estágio de pós-doutoramento de 13 meses no CERLIS (Centre de Recherche Sur Les Liens Sociaux), na Universidade Paris Descartes, na área da Sociologia da Infância. Tem experiência na área de Educação, com ênfase na educação para a infância, atuando principalmente nos seguintes temas: criança e infância, sociologia da infância, 
diferenças e relaçôes raciais, etárias e de gênero. Em 2010 recebeu a bolsa de produtividade nível 2.

Aparecida de Jesus Ferreira é Ph.D. em Educação de Professores e Linguística Aplicada pela Universidade de Londres, Inglaterra. Professora adjunta da UEPG (Universidade Estadual de Ponta Grossa), atuando no Programa de Pós-graduação em Linguagem, Identidade e Subjetividade e no Programa de Pós-graduação em Letras da Unioeste (Universidade Estadual do Oeste do Paraná). Tem experiência na área de Linguística Aplicada com ênfase em Formação de Professores, atuando principalmente nos seguintes temas: formação de professores (língua estrangeira e materna), prática de ensino de língua inglesa, ensino e aprendizagem de língua estrangeira, análise e desenvolvimento de materiais de ensino, letramento crítico e processos de construção de identidades sociais (relaçôes raciais). É parecerista em vários periódicos nacionais e internacionais. Publicou vários livros no Brasil e um nos Estados Unidos. É pesquisadora do NUREGS - Núcleo de Relaçôes Étnico-Raciais, de Gênero e Sexualidade na UEPG.

Edina Schimanski é Ph.D. em Educação pela Universidade de Londres, Inglaterra. Professora permanente do Programa de Pós-Graduação Ciências Sociais Aplicadas da UEPG. Participante do NUREGS e pesquisadora na área de Gênero, Meio Ambiente e Pobreza.

Ione da Silva Jovino é Formada em Letras-Português pela Pontifícia Universidade Católica de São Paulo. Possui mestrado e doutorado em Educação pela Universidade Federal de São Carlos. Atuou como professora de Português e técnica pedagógica na Educação Básica da rede pública em São Paulo entre os anos de 1994 e 2007. Realiza pesquisas e projetos de extensão nas áreas de relações étnicorraciais, juventude e infância. Atua como formadora nas áreas de metodologia de ensino, educação e diversidade étnico-racial. Desde 2007 é professora da Universidade Estadual de Ponta Grossa. Participa do Núcleo de Relaçóes Étnico-raciais, Gênero e Sexualidade (NUREGS/UEPG) e da Associação Brasileira de Pesquisadores e Pesquisadoras Negras. 
Jamil Cabral Sierra é Doutor em Educação pela Universidade Federal do Paraná UFPR, bolsista Capes/sanduíche no Instituto deEducação da Universidade de Lisboa (2012), mestre em Letras pela Universidade Estadual de Maringá (2004) e licenciado em Letras pela Universidade Estadual do Oeste do Paraná (1999). Atualmente, é Professor Adjunto da Universidade Federal do Paraná/UFPR - Setor Litoral. É vice-coordenador do Laboratório de Investigação em Corpo, Gênero e Subjetividade na Educação (UFPR/CNPq) e pesquisador do Núcleo de Estudo de Gênero (UFPR/CNPq). Tem experiência na área de Letras e Educação, com ênfase nos seguintes temas: discurso, relaçóes de gênero, diversidade sexual, corpo e subjetividade e suas conexóes com os estudos foucaultianos, especialmente aqueles ligados às noções de governamentalidade e estética da existência, bem como com os estudos queers.

Marly Catarina Soares possui graduação e Licenciatura em Letras pela Universidade Estadual de Ponta Grossa (1989), especialização em Língua Portuguesa pela Universidade Estadual de Ponta Grossa (1992), mestrado em Teoria e História Literária pela Universidade Estadual de Campinas (1998) e doutorado em Literatura pela Universidade Federal de Santa Catarina (2008). Atualmente é professora adjunta da Universidade Estadual de Ponta Grossa e membro de corpo editorial da UniLetras. Tem experiência na área de Letras, com ênfase em Literatura Brasileira, atuando principalmente nos seguintes temas: poesia do século XX, teoria literária, Florbela Espanca, literatura portuguesa, estudos literários e literatura e mulher.

Pascoalina Bailon de Oliveira Saleh é doutora em Linguística pela UNICAMP e professora associada da UEPG, onde atua no curso de Licenciatura em Letras e no mestrado em Linguagem, Identidade e Subjetividade. É membro do NUREGS, dedicando-se aos estudos sobre representaçôes de gênero, com ênfase na publicidade.

Paulo Vinicius Baptista da Silva possui Bacharelado e Licenciatura em Psicologia pela Universidade Federal do Paraná (1991), mestrado em Educação pela Universidade Federal do Paraná (1996) e doutorado em Psicologia Social pela Pontifícia Universidade Católica de São Paulo (2005). 
Atualmente é bolsita produtividade 2 do CNPQ, coordenador do Programa de Pós-Graduação em Educação (PPGE-UFPR), vice-coordenador do Grupo de Trabalho Educação e Relações Raciais da ANPED, representante da Região Sul na diretoria da Associação Brasileira de Pesquisadores Negros(as) (ABPN) e professor da Universidade Federal do Paraná, atuando no Programa de Pós-Graduação em Educação (PPGE-UFPR) e Núcleo de Estudos Afro-Brasileiros (NEAB-UFPR). Tem experiência na área de Educação, atuando principalmente nos seguintes temas: relações raciais, racismo, políticas afirmativas, construção social da infância e políticas para a infância.

Tereza Lopes Miranda é assistente social, graduada pela Universidade Estadual de Ponta Grossa. Mestre em Ciências Sociais Aplicadas pela UEPG. Participante do núcleo de Estudos "Questão Ambiental, Gênero e Condição de Pobreza. 


\section{SOBRE O LIVRO}

Formato

Tipologia

Papel

Impressão

Acabamento

Tiragem
$16 \times 23 \mathrm{~cm}$

Abadi MT, Adobe Garamond Pro, Franklin Gothic Book, Impact, Myriad Offset $90 \mathrm{~g}$ (miolo)

Cartão supremo $250 \mathrm{~g}$ (capa)

Gráfica Editora, Formulários Contínuos e Etiquetas F\&F Ltda

Costurado, colado, laminaçáo fosca, verniz localizado, shrink individual

500 exemplares 